\title{
CHARACTERISTICS OF THE MISSISSIPPIAN-PENNSYLVANIAN BOUNDARY AND \\ ASSOCIATED COAL-BEARING ROCKS IN THE SOUTHERN APPALACHIANS
}

By

Kenneth J. Englund, William H. Gillespie, C. Blaine Cecil, and John F. Windolph, Jr. U.S. Geological Survey and

Thomas J. Crawford West Georgia College with contributions by Cortland F. Eble West Virginia Geological Survey

Lawrence J. Rheams Alabama Geological Survey and Roger E. Thomas U.S. Geological Survey 
Characteristics of the Mississippian-Pennsylvanian boundary and associated coal-bearing strata in the central Appalachian basin.

Kenneth $\mathrm{J}$. Englund and Roger E. Thomas.......................

Upper Mississippian and Lower Pennsylvanian Series in the southern Appalachians.

Thomas J. Crawford $\ldots \ldots \ldots \ldots \ldots \ldots \ldots \ldots \ldots \ldots \ldots \ldots \ldots \ldots \ldots \ldots \ldots \ldots$

Biostratigraphic significance of compression-impression plant fossils near the Mississippian-Pennsylvanian boundary in the southern Appalachians.

William H. Gillespie, Thomas J. Crawford and Lawrence J. Rheams......... 11

Miospores in Pennsylvanian coal beds of the southern Appalachian basin and their stratigraphic implications.

Cortland F. Eble, William H. Gillespie, Thomas J. Crawford, and

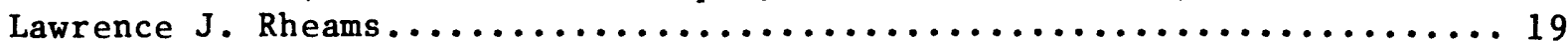

Geologic controls on sedimentation and peat formation in the Carboniferous of the Appalachian basin.

C. Blaine Cecil and Kenneth J. Englund...................... 27

Field Guide to Upper Mississippian and Lower Pennsylvanian coalbearing rocks in the southern Appalachians.

Kenneth J. Englund, William H. Gillespie, C. Blaine Cecil, John F. Windolph, Jr., and Thomas J. Crawford................ 35

Acknow ledgements........................................ 74

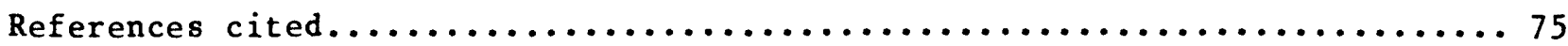




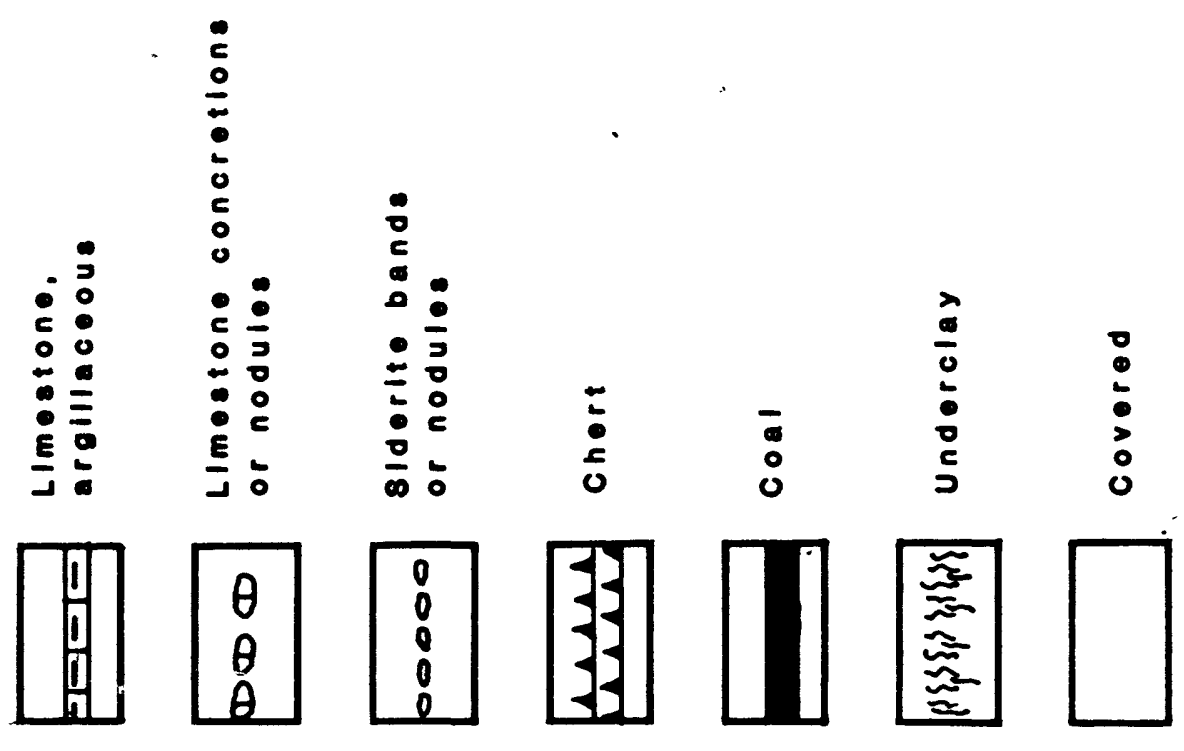

$\infty$
2
0
5
0
1
$\infty$
1
$=$

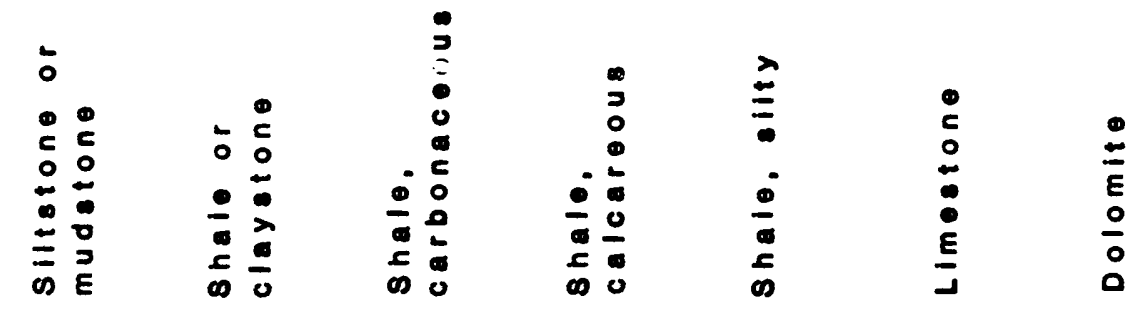
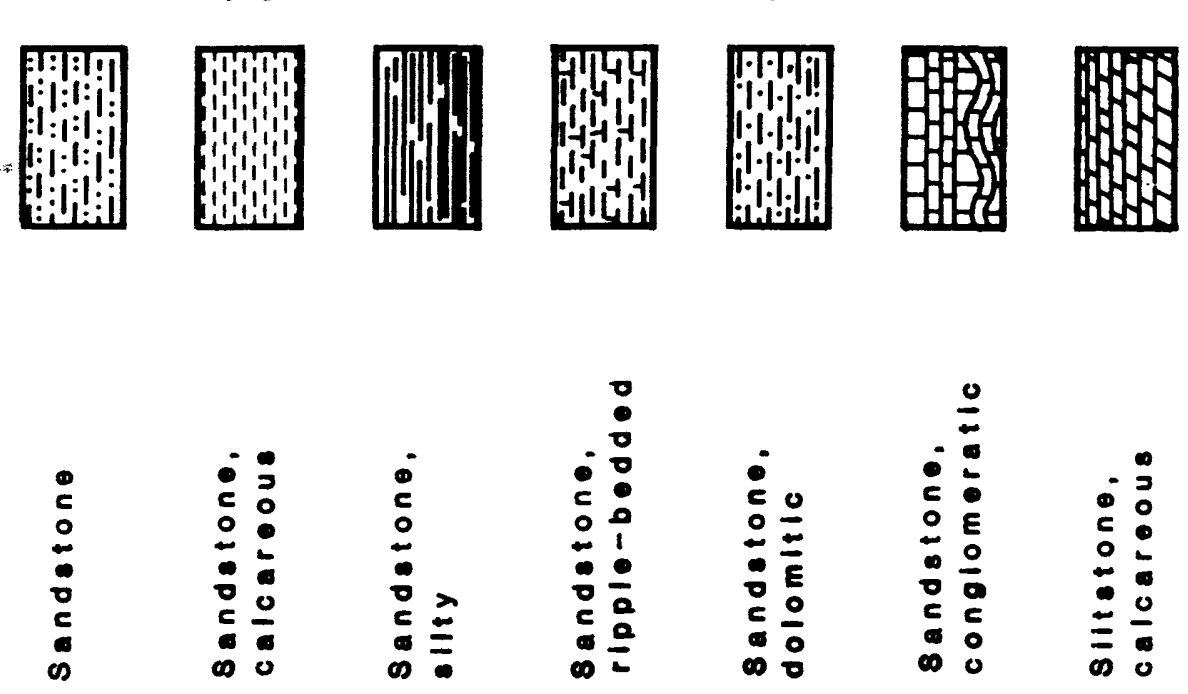

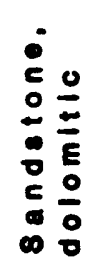

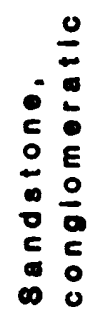

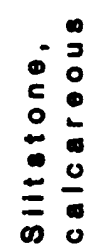
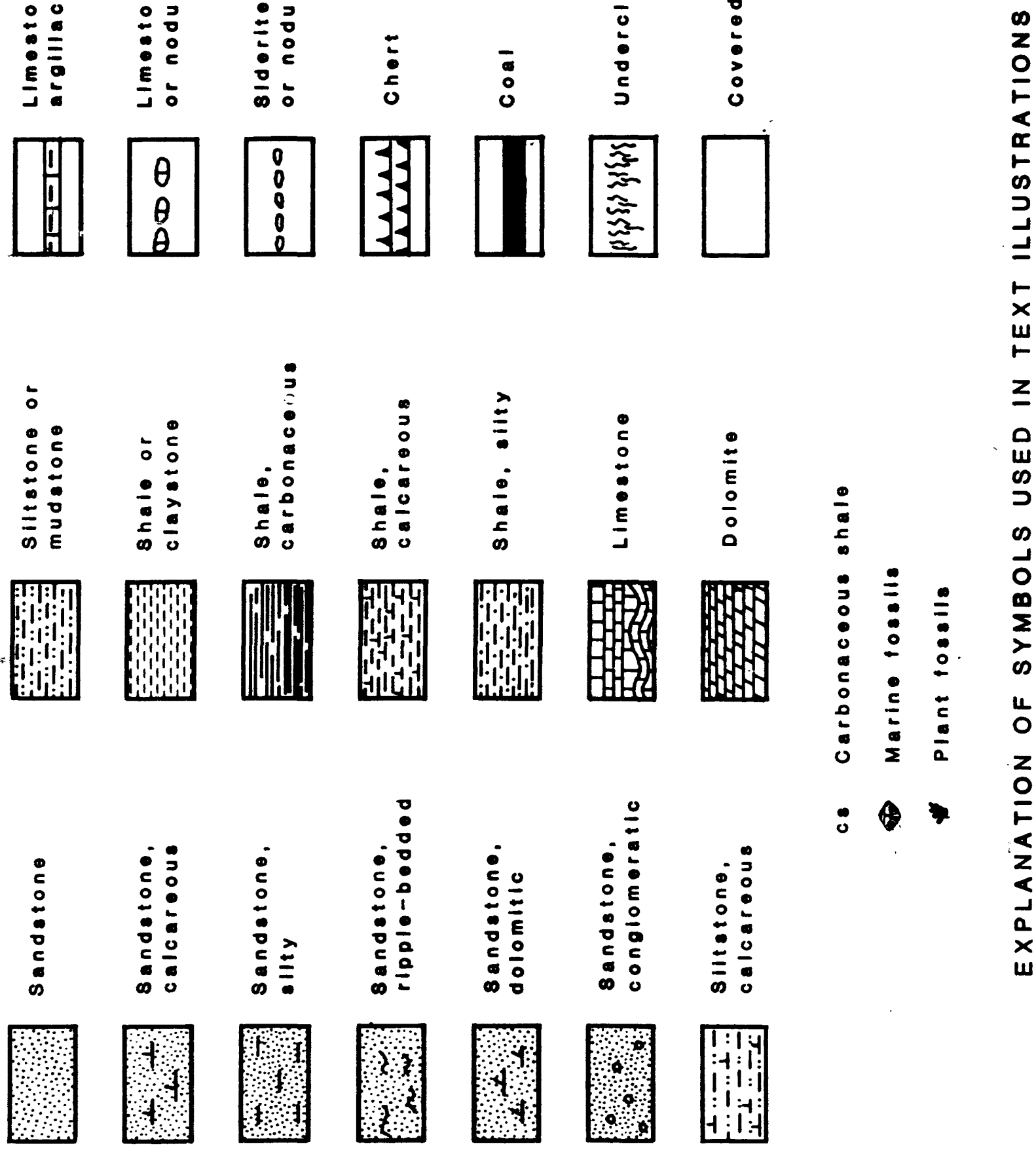


\title{
CHARACTERISTICS OF THE MISSISSIPPIAR-PERISYLVANIAN BOUTDARY AND ASSOCIATED COAL-BEARIFG ROCKS IN THR CEIIRAL APPAIACHIAR BASIR
}

\author{
Kenneth J. Englund ${ }^{1}$ and Roger E. Thomas ${ }^{1}$
}

\begin{abstract}
The boundary relationship between the Mississippian and Pennsylvanian Systems has been one of the most controversial aspects of Carboniferous stratigraphy in the central Appalachian basin. It has provided the impetus and subject matter for numerous papers, field trips, and symposia featuring widely divergent points of view concerning the position and character of the boundary.

Regionally, this boundary relationship is exacerbated by variations in the lithology, depositional environment, and age of associated strata and by the nature of the boundary contact. For example, involved strata vary lithically from marine limestone and shale to terrestrial coal-bearing clastics and, in age, from Early to latest Mississippian subjacent to the boundary and from oldest to Middle Pennsylvanian superjacent to the boundary. At the craton edge, the boundary is an unconformity with a significant hiatus but in the trough of the geosyncline, it is conformable in a continuously deposited sequence. Where unconformable, strata below the boundary exhibit incised drainage patterns, deep sink holes, and upland paleosol development. In the conformable trough area, the boundary is transcended by a coal-bearing facies of Late Mississippian to Early Pennsylvanian age. Biostratigraphically, the boundary is at the base of zone 4 of Read and Mamay (1964), specifically at the first appearance of Neuropteris pocahontas D. White. Below the boundary, terrestrial beds contain a newly recognized floral zone intermediate between floral zones 3 and 4 (Pfefferkorn and Gillespie, 1981a) and marine beds contain the youngest known Mississippian invertebrate fauna (Gordon and Henry, 1981).

Stratigraphically, the systemic boundary in the geosynclinal trough is placed at the gradational contact between the Bluestone and Pocahontas Formations, where the terrestrial coal-bearing sequence assigned to the Pocahontas (Lower Pennsylvanian) attains its maximum thickness of about $700 \mathrm{ft}$. However, the lower sandstone member or tongue of the Pocahontas Formation wedges out northwestward and, at its terminus, the boundary passes into the upper part of the Bluestone Formation at the contact between the Bramwell Member (Upper Mississippian), a well-defined marine unit, and the upper member (Lower Pennsylvanian) of the Bluestone Formation. This gradational nature of strata across the systemic boundary prevails in the geosyclinal trough but only where the Pocahontas and Bluestone Formations are present. These formations together with underlying Upper Mississippian units are truncated progressively northwestward by an unconformity that originates in the lower part of the overlying New River Formation (Lower Pennsylvanian). As a result of this truncation, the systemic boundary at the western edge of the basin is delineated by an unconformity that places Middle Pennsylvanian rocks assigned to the Lee and Breathitt Formations in contact with strata as old as the Borden Formation (Lower Mississippian).
\end{abstract}

IO.S. Geological Survey, Reston, Virginia 22092 


\section{INTRODUCTION}

The Mississippian-Pennsylvanian boundary has been treated as an unconformity throughout most of the eastern United States. In the central Appalachian basin the systemic boundary was placed historically at the contact between predominantly marine beds assigned to the Pennington and correlative formations of Mississippian age and coal-bearing beds of the Lee or equivalent formations of Early Pennsylvanian age. Inconsistencies in that practice were noted at the eastern edge of the Appalachian basin in Virginia by Wanless (1946, p. 11) who observed that "There seems to be a conformable transition from Mississippian sediments to the Early Pennsylvanian" and in Tennessee by Rodgers (1953, p. 111) who stated: "the contact thus records that change from marine to nonmarine deposition, but it may not be drawn at the same level everywhere".

The contact relation between the Pennington and Lee Formations, which previously were classified as Mississippian and Pennsylvanian in age, respectively, was demonstrated in the Cumberland Gap area of Kentucky, Tennessee, and Virginia by Englund and Smith (1960). In the tristate area, the Pennington-Lee contact had been drawn to include, in the Pennington Formation, varicolored shale, thin beds of limestone, and ripple-bedded sandstone and to include, in the Lee Formation, rocks consisting mostly of massive, quartzose conglomeratic sandstone. The tracing of thick conglomeratic sandstone members of the Lee Formation into thin ripple-bedded sandstone of the Pennington and the complementary wedging out of varicolored shale and limestone units of the Pennington between the Lee sandstone members demonstrated an intertonguing relation between the two formations. The contact varied several hundred feet stratigraphically and, as a consequence of the overlapping of the two formations, the lower or intonguing part of the Lee Formation was reclassified as Mississippian in age to reflect the contemporanous relation with beds of similar age in the Pennington Formation.

In the Pocahontas area of southwestern Virginia and southern West Virginia, the Mississippian-Pennsylvanian boundary, by definition and on the basis of paleontologic data, has been placed at the contact between the Bluestone and Pocahontas Formations (Hennen and Gawthrop, 1915; Reger, 1926; Cooper, 1961). This longstanding practice is recognized in the Pennsylvanian System stratotype section and at the eastern edge of the basin where the Pocahontas attains its maximum thickness. However, some modification of this concept was necessitated by the wedging out to the northwest of the lower sandstone member or basal tongue of the Pocahontas Formation into the upper beds of the Bluestone. Consequently, the systemic boundary extends from the base of the lower sandstone member, where it wedges out, into the upper part of the Bluestone Formation at approximately the contact between the Bramwell Member and the upper member of the Bluestone. This relationship, observed in the geosynclinal trough, terminates to the northwest where an unconformity truncates the Pocahontas Formation and the upper part of the Bluestone Formation. Thus, the transitional or gradational aspect of the beds at the systemic boundary in the southeast is replaced by a widely recognized hiatus to the northwest.

On the western edge of the Appalachian basin, widely divergent concepts have emerged regarding the boundary between the Mississippian and Pennsylvanian Systems. The longstanding practice of placing a major, regional unconformity at the systemic boundary (Miller, 1919) was verified by the geologic mapping of 
$71 / 2^{-}$quadrangles for the recent Kentucky Mapping Program. Studies relating to the reconstruction of depositional environments either have supported a regional unconformity (Englund and Windolph, 1971) or have advanced the concept that a facies relationship exists between the Mississippian and Pennsylvanian Systems (Horne and Ferm, 1970; Horne and others, 1971, 1974; Ferm and others, 1971; Ferm, 1974). Their Lee-Newman barrier shoreline model has been contested on both physical and biostratigraphic grounds by Ettensohn and Dever (1975); Ettensohn (1977, 1979); and Ettensohn and Peppers (1979). A third concept places an unconformity between the Mississippian and Pennsylvanian Systems on structural highs and continuous deposition between the systems in structural lows (Haney, 1979).

In the southern part of the Appalachian basin, both unconformable and transitional relations have also been described for the boundary between the Mississippian and Pennsylvanian Systems. Ferm and Ehrlich (1967) used a deltaic depositional model to explain a transitional relation between the systems in northern Alabama whereas Schweinfurth and others (1981) presented physical stratigraphic and paleontologic data to document a substantial hiatus at the systemic boundary. Likewise, in northwestern Georgia, Culbertson (1963) described an unconformity between the systems and Cramer (1979) placed the systemic boundary within transitional lithofacies. Similarly, both unconformable and gradational relations have been recognized at the Mississippian-Pennsylvanian boundary in Tennessee.

The depositional environment of strata near the boundary is equally controversial. For example, widespread deposits of orthoquartzite or quartz arenite have been interpreted as offshore bars, tidal channels, and barrier bars of a marine environment or as distributary channels, braided streams, or delta lobes of a terrestrial environment.

This guidebook attempts to focus attention on multiple aspects of the Mississippian-Pennsylvanian boundary relation in the southern Appalachians between the Pennsylvanian System stratotype section in southeastern West Virginia and the correlative section in northern Georgia. Models are used to illustrate the significance and interrelation of the systemic boundary and the deposition and distribution of closely associated coal-bearing strata.

\section{STRATIGRAPHIC RELATIONSHIPS}

Upper Mississippian and Lower Pennsylvanian rocks in the central Appalachian basin and in nearby outcrop belts of the faulted and folded Appalachians constitute a southeastward-thickening clastic wedge as much as $5,000 \mathrm{ft}$ thick. These strata are assigned to seven formations, in ascending order: the Greenbrier Limestone, Bluefield Formation, Hinton Formation, and Princeton Sandstone of Late Mississippian age; the Bluestone Formation of Late Mississippian and Early Pennsylvanian age; and the Pocahontas and New River Formations of Early Pennsylvanian age ( $f i g .1)$. Of this sequence, the Greenbrier Limestone represents the thickest and most widespread marine incursion. It consists mostly of medium-gray, thick-bedded, very finely to coarsely crystalline limestone with a few beds that are oolitic, cherty, or argillaceous. Marine invertebrates are found throughout the formation. Marine deposition also prevailed during the deposition of much of the overlying Bluefield Formation. This formation consists largely of medium- to medium- 


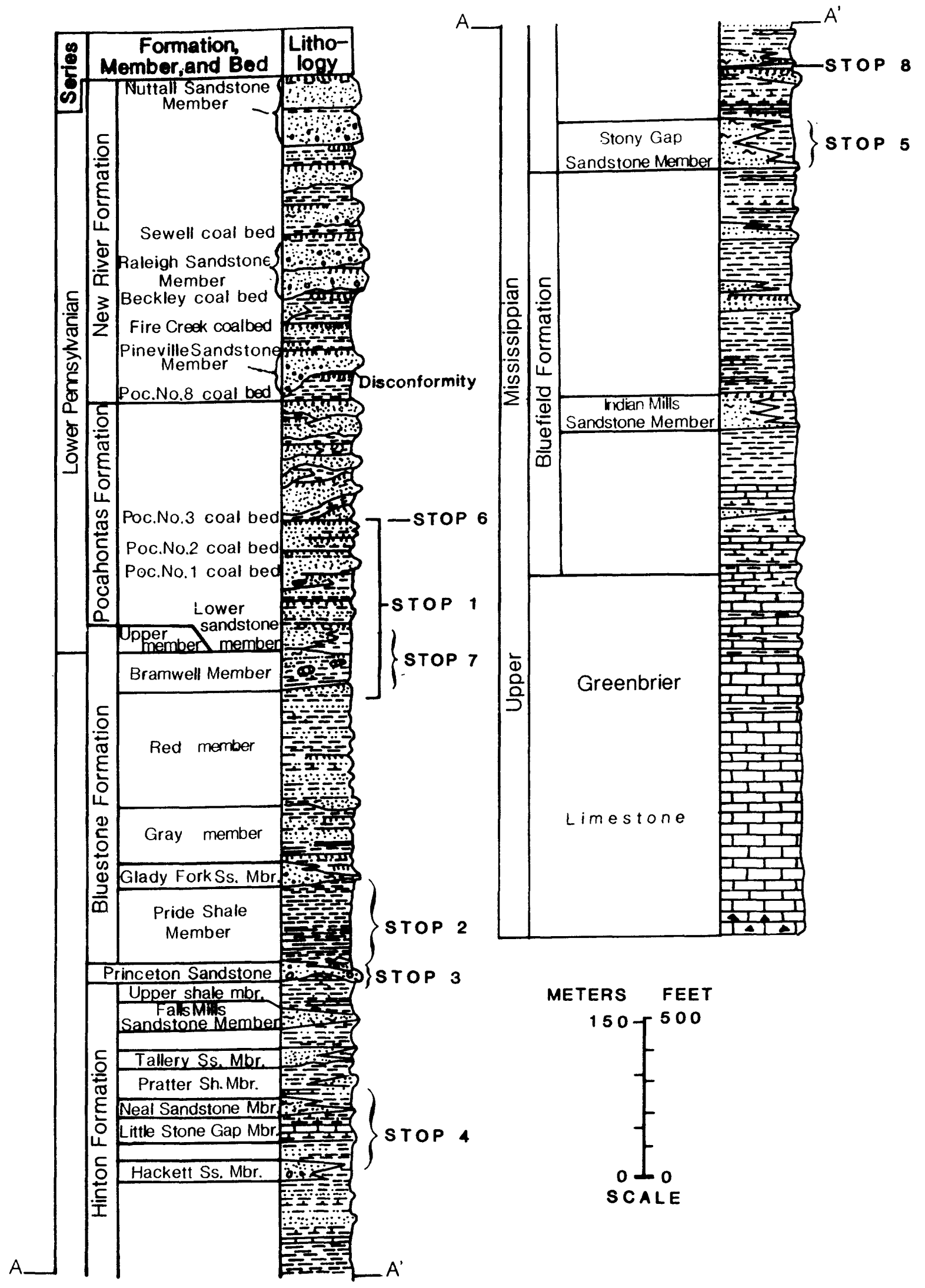

Figure 1. Generalized stratigraphic section of Upper Mississippian and Lower Pennsylvanian Series in east-central Appalachian basin. Stops 1-8 are shown. 
dark-gray, greenish-gray, and grayish-red, partly calcareous shale interbedded with limestone and argillaceous 1 imestone. In easternmost exposures, the formation includes siltstone and sandstone beds as much as $80 \mathrm{ft}$ thick, and a few coal beds. These coal beds and associated rooted underclay and carbonaceous shale represent the first seaward encroachment of terrestrial mud, sand, and fresh-water swamp deposits in Late Mississippian time. Limestone and calcareous shale beds, which predominate in the lower part of the formation, contain abundant marine fossils including brachiopods, bryozoans, crinoids, and blastoids. Plant fossils are found locally in the formation. Minor periodic regressions during Bluefield deposition mark the beginning of a regressive trend that accelerated with the deposition of later Mississippian and Early Pennsylvanian sediments.

The Bluefield is overlain by the Hinton Formation which is characterized by an abundance of grayish-red, partly calcareous shale and siltstone with minor amounts of medium-gray and greenish-gray shale, sandstone, fossiliferous limestone, and coal or carbonaceous shale underlain by rooted underclay. In the easternmost outcrops, the coal beds are as much as 30 in. thick and are associated with fossil plant-bearing shale. The basal unit of the Hinton, the Stony Gap Sandstone Member, is a well-sorted orthoquartzite that was deposited as a sequence of coalescing of fshore bars (Englund and others, 1979, fig. 10). The thickest and most widespread of several marine units in the formation is the Little Stone Gap Member or Avis Limestone of Reger (1926). It is an abundantly fossiliferous limestone and calcareous shale as much as $100 \mathrm{ft}$ thick. The upper part of the formation contains several widely distributed sandstone members including a locally conglomeratic orthoquartzite identified as the Tallery Sandstone Member. During deposition of these units of the Hinton Formation, shallow-marine, barrier-bar, tidal-flat, and fresh-water swamp environments prevailed.

The Hinton is disconformably overlain by the Princeton Sandstone which ranges mostly from a polymictic conglomerate to a coarse conglomeratic subgraywacke as much as $60 \mathrm{ft}$ thick. Its matrix is light-gray, fine- to coarse-grained, thick-bedded to massive, calcite-cemented sandstone. Clasts in the formation are diverse in composition, size, and abundance, and consist of we1l-rounded to angular fragments of quartz, shale, siltstone, limestone, chert, and ironstone. The variety of lithic fragments, ranging from locally derived limestone and shale to quartz and chert from more distant sources, indicate that the Princeton was deposited on a highly eroded surface where clasts were reworked by storm waves and longshore currents associated with a marine incursion at the base of the overlying Bluestone Formation.

Except for a decrease in marine influence, the depositional environment and lithology of strata in the Bluestone Formation are similar to those of the Hinton. The widespread Pride Shale Member at the base of the Bluestone is mostly shale or dark-gray silty shale that contains sparse marine and brackish-water faunal assemblages and fossil plants. Basal beds locally include greenish-gray and grayish-red shale and thin coal beds. It represents predominantly silt and clay infilling of a large shallow marine embayment or lagoon. The Pride is overlain locally by the conglomeratic Glady Fork Sandstone Member containing tidal-creek and other intertidal sediments. The gray member, overlying the Glady Fork and merging with the Pride in areas beyond the distribution of the Glady Fork, represents a major seaward progradation of terrestrial coal-bearing deposits. In addition to several thin 
coal beds, the gray member contains beds of carbonaceous shale with fresh- or brackish-water ostracodes and pelecypods. The overlying red member is a sequence of mostly grayish-red, partly calcareous shale and siltstone deposited in a tidal-flat enviroment associated with fresh-water marshes. It also contains several thin beds of coal, underclay, and nodular argillaceous limestone. The Bramwell Member, the youngest Mississippian strata in the Bluestone, was deposited during marine transgression across the lower coastal plain underlain by the red member. Carbonaceous shale containing fresh- and brackish-water faunas, found at the base of the Bramwell, grades upward to silty shale and calcareous siltstone that contain thin 1 imestone beds and highly diverse marine faunas. The Bramwell Member together with the greenish-gray and grayish-red shale of the upper member of the Bluestone Formation constitute a prodeltaic sequence that preceded and later overlapped the deposition of the basal deltaic wedge or lower sandstone member of the Pocahontas Formation.

The depositional trends established in Late Mississippian time show that the Appalachian seaway slowly regressed toward the northwest in a series of regressive-transgressive events, thereby producing a predominance of terrestrial coal-bearing sediments in the east-central Appalachian basin by Early Pennsylvanian time. The earliest Pocahontas deposits consisted of sand which accumulated as a series of merging delta lobes that prograded toward the northwest over the nearshore marine muds (fig. 2). The coarsest sediments, including sand and quartz-pebble gravel, accumulated in the major distributary channels. The orientation of the lobes in conjunction with decreasing grain size toward the edges of the lobes show that clastics prograded to the northwest from a southeastern source, continuing the trend established in underlying Mississippian strata. During deposition of the upper part of the lower member of the Pocahontas Formation, decreasing sand dispersal was accompanied by a southeastward encroachment by nearshore muds of the upper member of the Bluestone Formation over areas of relatively thin sand, mostly in the interlobe areas. At the top of the lower sandstone member of the Pocahontas, very fine grained sand graded into silt and clay, including several feet of rooted underclay, on the lobe surfaces prior to the accumulation of peat. Widespread peat accumulation recorded by as much as $4 \mathrm{ft}$ of coal in the Squire Jim coal bed coincided with a stillstand--a period when the influx of clastics was minimal. The reworking of sand along the stabilized shoreline led to the development of a barrier system consisting of lithically and texturally mature quartz sand. Growth of this barrier system continued during the initial deposition of the middle sandstone member of the Pocahontas Formation which consists of several coalescing lobes between the Squire Jim and Pocahontas No. 3 coal beds. Delta lobe switching in this interval is marked by local peat deposition represented by relatively thin Pocahontas No. 1 , No. 2 , and No. 2A coal beds. The major lobes of the middle member are superimposed over those of the lower sandstone member. Sand at the distal edges of the lobes was reworked and winnowed by waves and longshore currents and, as a result, the barrier system is thickest just seaward of the major distributary lobes. Continued marine regression during deposition of the upper part of the middle sandstone member was accompanied by a northwestward progradation of sand in distributary channels over and beyond the barrier system. As the distributary systems of the middle sandstone member waned, fine-grained terrigenous sediments, including silt and clay, accumulated over the lobes. Subsequent abandonment of clastic sedimentation permitted the development of an extensive swamp in which very thick peat, represented by the Pocahontas No. 3 coal bed, was deposited. 
The No. 3 is the thickest and most widely distributed of the Pocahontas coal beds, attaining thicknesses of $42 \mathrm{in.}$ or more over large areas. Variations in the thickness of the Pocahontas No. 3 coal bed indicate that the thickest peat accumulated over abandoned distributary lobes. However, for the first $t$ ime in the sequence, the coal swamp also extended well beyond the lobes and across the former interdistributary and back-barrier areas. The unusual extent of the Pocahontas No. 3 can be attributed to the abandonment of the main distributary systems and the minimal influx of terrigenous clastics. Deltaic sedimentation resumed in the upper part of the Pocahontas and several coal beds, including the relatively thick Pocahontas No. 4 and No. 6, resulted from the accumulation of peat on abandoned delta lobes.

The Pocahontas Formation is conformably overlain by the New River Formation in easternmost outcrops. The contact, at the base of the Pocahontas No. 8 coal bed, extends conformably northwestward for several miles to the point of truncation by the unconformity at the base of the Pineville Sandstone Member of the New River Formation. Northwest of the area underlain by the Pocahontas Formation, the uppermost beds of the Bluestone Formation also are eroded, and the disconformity at the base of the New River coincides with the widespread Mississippian-Pennsylvanian unconformity. The New River Formation ranges in thickness from $800 \mathrm{ft}$ along the New River in the type area in western Fayette County, West Virginia, to about $1,000 \mathrm{ft}$ in the eastermost outcrops. This formation is a coal-bearing sequence of sandstone, siltstone, shale, and underclay that is lithically similar to the Pocahontas Formation except for the presence of thicker and more widespread beds of quartz-pebble conglomerate and quartzose sandstone. Quartzose conglomeratic sandstone is also characteristic of correlative beds of the Lee Formation in Virginia, Kentucky, and Tennessee. Deposits of quartzose sandstone are 1 inear, oriented parallel to the southeastern edge or shoreline of the basin, and occupy an intermediate position between back-barrier coal-bearing strata to the southeast and intertonguing marine strata to the northwest. The clean well-washed character, geometry, and facies relation of these sandstone deposits indicate the intense winnowing action of waves and tidal or longshore currents associated with barrier- or of $f$ shore-bar development.

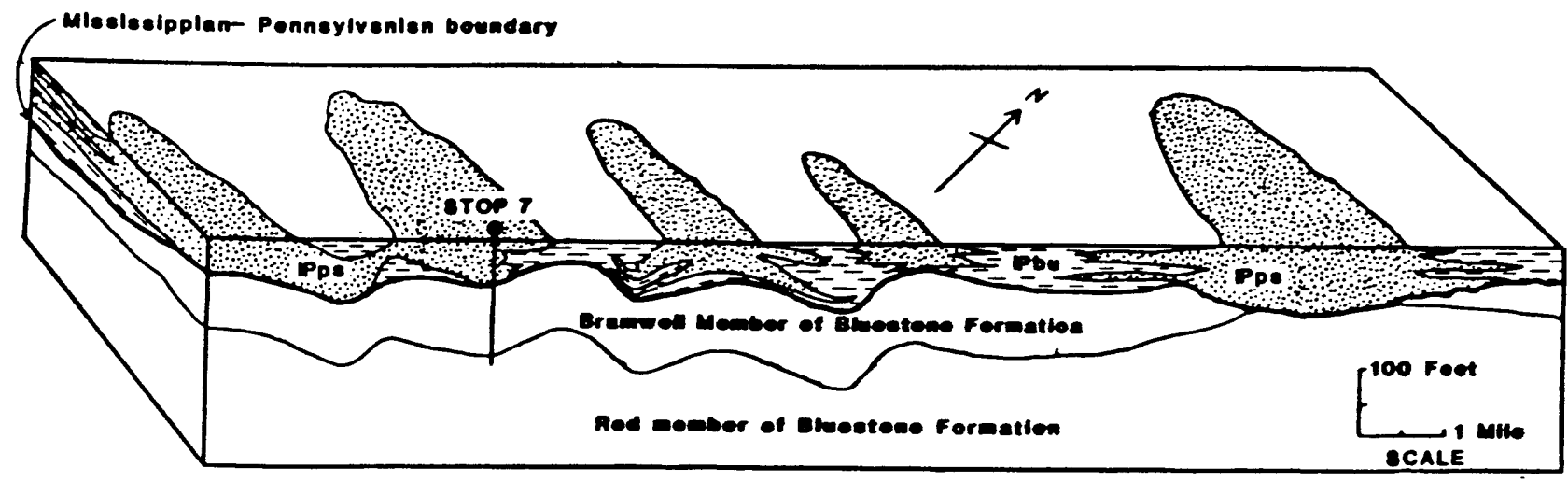

Floure 2. Generallzed block dlagram showing intertonguing betweon lower eandetong mombor of Pocahontas Formation ( IP $p$ ) and upper member of bluestone Formatlon ( Pbu) In Bramwell. Va..-W.Va.. area. Location of stop 7 la shown. 

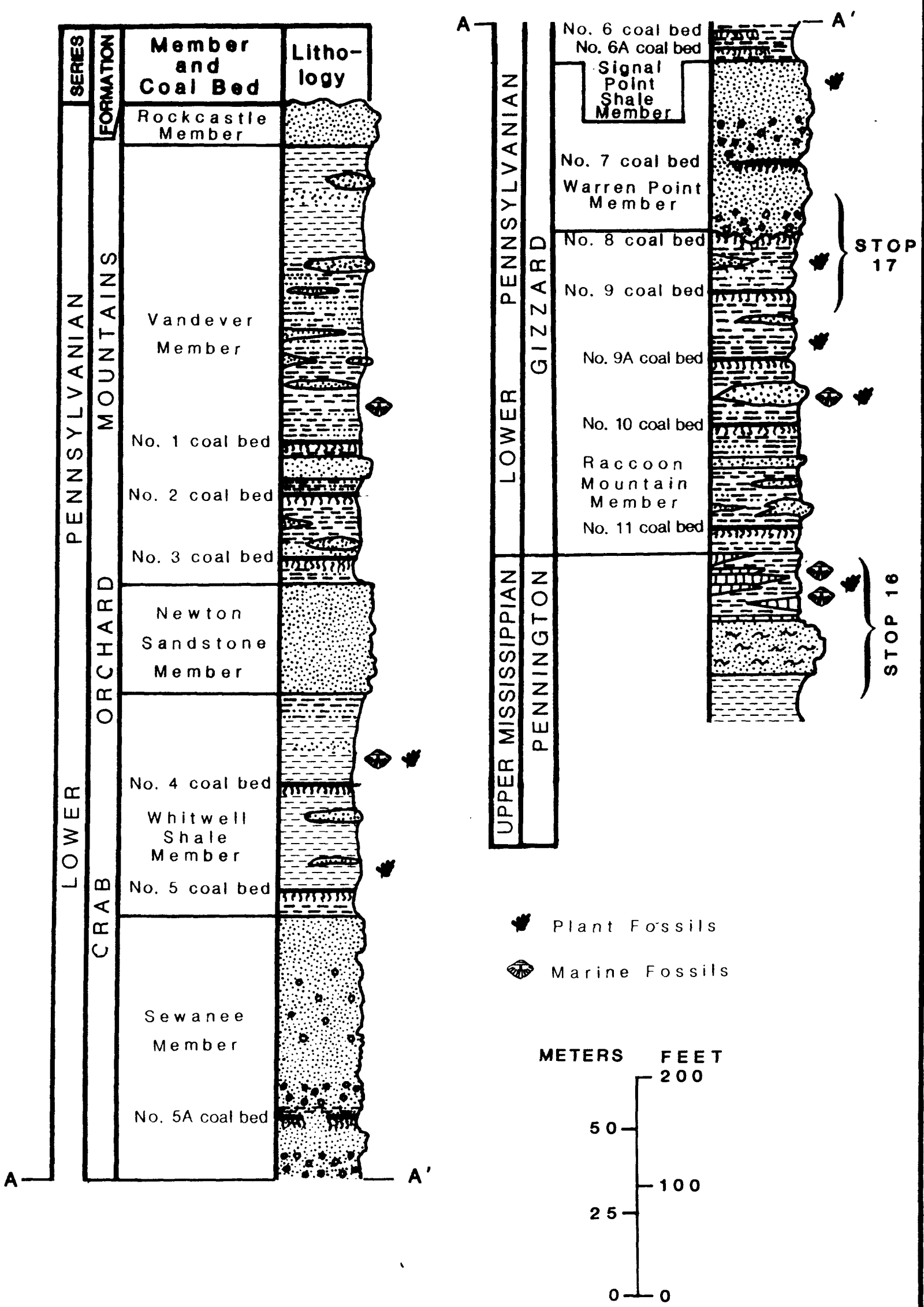

Figure 3. Generalized stratigraphic section of uppermost Mississippian and Lower Pennsylvanian Series in northwestern Georgia. Stops 16-17 are shown. 


\title{
UPPER MISSISSIPPIAN AND LOWBR PENISYLVANIAN SERIBS IN THB SOUTHERT APPAIACHIAR BASIN
}

\author{
Thomas J. Crawford 1
}

\begin{abstract}
Upper Mississippian and Lower Pennsylvanian rocks in the tri-state area of Tennessee, Alabama, and Georgia occur in a southeastward thickening wedge as much as $3,000 \mathrm{ft}$ thick. Seven formations are recognized in this carbonate-clastic wedge, in ascending order: the Tuscumbia Limestone, Monteagle Limestone, Hartselle Sandstone, Bangor Limestone, and Penningt on Formation of Late Mississippian age and the Gizzard and Crab Orchard Mountains Formations of Early Pennsylvanian age. In the lower part of this sequence, the formations consist mostly of medium-gray, thick-bedded, very finely to coarsely crystalline, oolitic limestone that contains abundant marine invertebrate fossils. Marine deposition continued throughout Late Mississippian time but waned in the Pennington Formation and in overlying units with the periodic seaward advancement of nearshore muds and sands.
\end{abstract}

\section{STRATIGRAPHIC RELATIONSHIPS}

The Pennington Formation consists mostly of medium- to dark-gray, partly calcareous shale interbedded with limestone and dolomite ( $f i g .3$ ). In eastern exposures, the formation also includes siltstone and sandstone beds as much as $60 \mathrm{ft}$ thick and a few plant fossil-bearing beds. Marine invertebrate and fossil plants indicate that the Pennington is of Late Mississippian (Chesterian) age (T.W. Henry, Mackenzie Gordon, Jr., written comm., 1984; and Gillespie and Crawford, 1983).

The earliest Pennsylvanian deposits, assigned to the Raccoon Mountain Member of the Gizzard Formation, consist of interbedded shale, siltstone, and fine- to medium-grained lenticular sandstone beds. Siderite nodules, flaser bedding, or shale clasts are common in some beds. In Georgia, the Raccoon Mountain Member has a maximum thickness of about $275 \mathrm{ft}$ near its type locality, Scratch Ankle Hollow, at the northern end of Sand Mountain. In that area, the lenticular sandstone beds are best developed and some attain a thickness of about $40 \mathrm{ft}$. Five coal beds occur in the member: the Etna (No. 8), Dade (No. 9), Rattlesnake (No. 9A), Red Ash (No. 10), and Mill Creek (No. 11). Southward and eastward, the Raccoon Mountain Member thins to less than $100 \mathrm{ft}$, sandstone beds are thinner $(10-15 \mathrm{ft})$, and there are fewer coal beds. Plant fossils in the member indicate an late Early Pennsylvanian age and correlation with the New River Formation of the Pennsylvanian System stratotype (Gillespie and Crawford, 1983). The overlying Warren Point Member is a medium- to coarsegrained sandstone with extensive lenses of quartz-pebble conglomerate in the lower and upper parts. Low-angle planar crossbedding is common. The base is uneven and includes channels cut into underlying beds of the Raccoon Mountain Member. Basal "rubble beds" contain abundant shale and siderite clasts and 
distorted lenses of coal. Thicknesses of the Warren Point range from less than $100 \mathrm{ft}$ to more than $200 \mathrm{ft}$ and average about $150 \mathrm{ft}$. The member weathers massively and is a prominent cliff former. The Cliff (No. 7, or Underwood) coal bed occurs locally in the Warren Point.

The Signal Point Shale Member, at the top of the Gizzard Formation, is dark-gray shale and flaser-bedded silty shale. Locally, it contains a substantial amount of siltstone and thin-bedded sandstone. Thicknesses range from less than $20 \mathrm{ft}$ to more than $100 \mathrm{ft}$, with a 40 to $60-\mathrm{ft}$ range being most common. The Upper C1iff No. 1 (No. 6) coal bed occurs in the upper part and the Upper $\mathrm{Cl}$ iff No. 2 (No. 6A) coal bed in the lower part of the member.

The Sewanee Member, at the base of the Crab Orchard Mountains Formation, is primarily a fine- to coarse-grained sandstone with well-developed planar crossbedding. It is also feldspathic and thin bedded but thick massive beds of quartz-pebble conglomerate are particularly common near the base and immediately above a middle shale unit. The lower part also contains coal and shale clasts and lenticular sandstone beds that occupy channels or intertongue with shale and siltstone of the underlying Signal Point Member. The Sewanee is about 250-300 ft thick, weathers massively, and is a prominent cliff former. A thin shale near the middle of the member is commonly less than $20 \mathrm{ft}$ thick and contains the Lahusage (No. 5A) coal bed.

The Whitwell Shale Member of the Crab Orchard Mountains Formation is about $200 \mathrm{ft}$ thick and consists of interbedded shale, siltstone, and fine-grained sandstone. Flaser bedding is common in the shale and siltstone and thin planar crossbed sets occur in the sandstone which is generally thin bedded and lenticular. The Tatum (No. 4) coal bed 1 ies 50 to $100 \mathrm{ft}$ below the top and the Sewanee (No. 5) coal bed 1 ies approximately 15 to $20 \mathrm{ft}$ above the base of the member.

The Newton Sandstone Member of the Crab Orchard Mountains Formation is mostly feldspathic, fine- to coarse-grained sandstone in beds and crossbed sets less than $3 \mathrm{ft}$ thick. It is al so partly medium bedded or massive. Thicknesses are estimated to vary from about 100 to $150 \mathrm{ft}$.

The Vandever Member of the Crab 0rchard Mountains Formation is a $400 \mathrm{ft}$ thick sequence of interbedded shale, siltstone, and sandstone that include three coal beds. A persistent sandstone bed, varying from 20 to $30 \mathrm{ft}$ thick, occurs about $70 \mathrm{ft}$ above the base of the member and $15 \mathrm{ft}$ below the A (No. 1) coal bed. The Durham Marker (No. 2) coal bed is about $15 \mathrm{ft}$ below the base of the sandstone and the Durham (No. 3) coal bed is about $10 \mathrm{ft}$ above the base of the Vandever Member. A bed of marine invertebrate fossils is found about $10 \mathrm{ft}$ above the A (No. 1) coal bed.

The youngest Pennsylvanian strata in Georgia cap two small knobs on Round Mountain south-southwest of Durham, Georgia. These are correlated with the Rockcastle Member and consist of 20 to 30 ft of medium-grained, slightly feldspathic, crossbedded sandstone in beds up to $4 \mathrm{ft}$ thick.

Strata of Pennsylvanian age were deposited primarily in terrestrial environments including coastal swamps that were periodically encroached by deltaic-fluvial systems. 


\section{BIOSTRATIGRAPHIC SIGKIFICANCE OF COMPRESSION - IMPRESSION PLANT FOSSILS MEAR THE MISSISS IPPIAN - PEIMSYLVARLAN BOURDARY IN THB SOUTHERT APPALACHLANS}

William H. Gillespie ${ }^{1}$, Thomas J. Crawford ${ }^{2}$, and Lawrence J. Rheams ${ }^{3}$

\section{ABSTRACT}

Plant megafossils collected from below and above the lithologically defined Mississippian-Pennsylvanian boundary in the area of the Pennsylvanian System stratotype section in Virginia and West Virginia indicate a significant change in the flora between the two systems. This change is at the Namurian A-B boundary of western and central Europe. In northwestern Georgia, plant megafossils collected from the upper part of the Pennington Formation indicate a Late Mississippian age (Namurian A) and those collected from strata associated with the 11 coal beds of the overlying Gizzard and Crab Orchard Mountains Formations indicate an late Early Pennsylvanian (New River) age when compared with the Pennsylvanian System stratotype section and a Westphalian A age when compared with European chronostratigraphic zonations. In Alabama, plant megafossils collected from the Parkwood Formation in the type section near Birmingham indicate that strata assigned to the formation in that area are Late Mississippian and Early Pennsylvanian in age. Plant megafossils collected from strata associated with coal beds in the Warrior, Cahaba, Coosa, and Plateau coal fields indicate an Early Pennsylvanian age.

\section{INTRODUCTION}

Plant megafossils collected at 11 localities from strata $0-750 \mathrm{ft}$ below and at 35 localities from strata $0-650 \mathrm{ft}$ above the Mississippian-Pennsylvanian boundary in the Pennsylvanian System stratotype study area in Virginia and West Virginia (Englund and others, 1979) provided conclusive proof of a significant floral change at the boundary (Gillespie and Pfefferkorn, 1977, 1979a,b; Pfefferkorn and Gillespie, 1979, 1981b, 1982). This floral change corresponds to the "Florensprung" (Gothan, 1952; Havlena, 1982) or floral break (Kidston, 1923) which occurs in Europe at the boundary between the Namurian $A$ and $B$ chronostratigraphic stages or, as based on faunal remains, at the base of the Kinderscoutian or " $R$ " goniatite zone (Wagner, 1982a). Bode (1958), Bouroz and others (1978) and Wagner (1982a) all look upon this break as a useful stratigraphic marker throughout the paleoequatorial belt of Carboniferous strata.

In northwestern Georgia, compression-impression floras have been collected at 35 localities from Pennsylvanian strata and at 3 localities from the Upper Mississippian Pennington Formation (Gillespie and Crawford, 1983). The systemic boundary between the Mississippian and Pennsylvanian Systems in Georgia has been placed, in the absence of biostratigraphic data, at the

IU.S. Geological Survey, 916 Churchill Circle, Charleston, West Virginia 25314

${ }^{2}$ Geology Department, West Georgia College, Carrollton, Georgia 30118

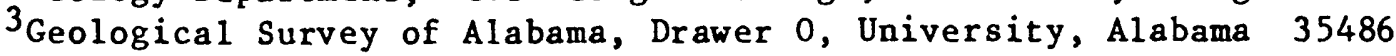


contact between the Pennington Formation and the Raccoon Mountain Member of the Gizzard Formation (Thomas and Cramer, 1979). The plant megafossil data support this designation.

Rocks of Carboniferous age crop out throughout northern Alabama and occur in the subsurface throughout most of the rest of the State (Thomas, 1979; Smith, 1979). Plant megafossils collected from 9 outcrops, 14 surface mines, and 60 cores indicate that the Parkwood Formation is of Mississippian and Pennsylvanian age in its type area and that the coal beds in the Warrior, Cahaba, Coosa, and Plateau coal fields are of Early Pennsylvanian age as based on the Pennsylvanian System stratotype section and of Westphalian $A$ age as based on the European chronostratigraphic zonation.

\section{PREVIOUS WORK}

The most detailed early treatments of the Mississippian flora are by White $(1900,1926,1943)$. In 1926, White described the general features of the Mississippian flora of the Appalachian trough and recognized a lower, or Pocono phase, and an upper, or Chester phase, but he only hinted at the existence of additional divisions. Jongmans and Gothan (1934), Jongmans (1937), and Jongmans and others (1937) called attention to a flora, previously unreported from North America, that was similar to certain floras in the lower Namurian of Europe. Bertrand (1934, 1935) also discussed the similarity of fossil floras found on the two continents.

The zonation paper of Read and Mamay (1964) was the first to consider the combined Carboniferous and Permian section. They distinguished 15 floral zones; 3 in the Mississippian, 9 in the Pennsylvanian, and 3 in the Permian. They reported different megafloras above and below the MississippianPennsylvanian boundary and assigned zone numbers 3 and 4 to these floras but did not provide range charts for the critical taxa. Read and Mamay predicted that another and different flora might later be found between zones 3 and 4.

A comprehensive range chart for the North American floras was provided by Pfefferkorn and Gillespie (1979) in their preliminary paper on the flora of the proposed Pennsylvania System stratotype in Virginia and West Virginia. They drew comparisons with the chronostratigraphic stages of western Europe for which the ranges of fossil plants are reasonably well known.

\section{MATERIALS}

The plant fossils discussed in this paper from Virginia-West Virginia were collected from stratigraphic sections measured for the Pennsylvanian System stratotype project and from nearby areas that were also mapped by project geologists (Pfefferkorn and Gillespie, 1981b). Those from Georgia were collected during an intensive geologic mapping program of several years duration sponsored by the U.S. Geological Survey (Gillespie and Crawford, 1983); and those from Alabama were collected, for the most part, as an adjunct to the cooperative coal quality sampling program with the Alabama Geological Survey (Gillespie and others, 1985b). The fossil names in this paper are those used historically in the United States. 
RESULTS

The major species found in the area of the Pennsylvanian System stratotype section are listed in Table 1 (Gillespie and Pfefferkorn, 1979a; Pfefferkorn and Gillespie, 1981b, 1982). Floras are sparse in the Bluefield and Hinton Formations and only isolated stem casts are found in the Princeton Sandstone.

In general, the Late Mississippian flora is characterized by Stigmaria stel lata Geoppert, Spenopteris elegans (Brongiart) Sternberg, and Sphenophyllum tenerrimum Ettingshausen. Accessory species of stratigraphic importance in this interval include Pecopteris aspera Brongniart, Lyginopteris fragilis Schotheim, L. bermudensiformis Schlotheim, Calamites radiatus (Brongniart) Remy (Archaeocalamites Stur), Sphenopteridium bifidum (Lindley and Hutton) Tschirk, Archaeopteridum tschermackei (stur) Kidston, and sphenopteris launoitii Stockmans and Williere. This flora differs from that in the Read and Mamay (1964) zone 3 which is characterized primarily by Fryopsis abbensis (Read) Wolfe and Spenopteridium brooksi Read and seemingly is most prevalent in the strata immediately overlying the Greenbrier Limestone in Tazewell County, Virginia. It also differs from the Read and Mamay floral zone 4 as characterized by Neuropteris pocahontas David White, Sphenopteris pottsvillea (David White) Gastaldo and Boersma, Asterophyllites charaeformis (Sternberg) Geoppert and Lyginopter is hoeninghausi (Brongniart) Potonie. Consequently, the Read and Mamay zone 3 flora, Gillespie and Pfefferkorn's intermediate flora (as predicted earlier, but never found by Read and Mamay), and the Read and Mamay zone 4 flora differ in species composition and therefore are stratigraphically useful.

The systemic boundary between the Mississippian and Pennsylvanian Systems in Georgia has been placed historically at the contact between the Pennington Formation and the Raccoon Mountain Member of the Gizzard Formation (Thomas and Cramer, 1979). The occurrence of Archaeopteridium tschermackei in the upper part of the Pennington Formation indicates that this unit is probably of latest Late Mississippian age or comparable to the Late Mississippian Bluestone Formation of Virginia and West Virginia.

The oldest strata containing plant megafossils in the Raccoon Mountain Member occur approximately $100 \mathrm{ft}$ above the base of the member at its type locality, Scratch Ankle Hollow, near Trenton, Georgia. The flora in the roof shale of the No. 10 or Red Ash coal bed contains Neuropteris pocahontas (David White), N. smithi Lesquereux and Spheopteris pottsvillea (David White) Gastaldo and Boersma, which are all indicative of a Lower Pennsylvanian flora.

Plant megafossils have been also collected from shale beds associated with al 1 of the other Pennsylvanian coal beds in Georgia. Some of the collections are extensive, especially those associated with the No. 3 and No. 5 coal beds. These floras are remarkably similar in species content, and commonly occurring enities include sigillaria elegans Brongniart, Lepidophloios laricinus Sternberg, Lepidodendron aculeatum Sternberg, L. obovatum Sternberg, Calamites spp., Asterophyllites charaeformis (Sternberg) Geoppert, A. grandis sternberg, Annularia asteris Bell, Sphenophyllum cuneifolium (Sternberg) Zeiller, Neuropteris pocahontas David White and varieties, N. smithi David White, N. cf. hollandica Stockmans, Sphenopteris hoeninghausi (Brongniart) Potonie, S. pottsvillea (David hite) Gastaldo and Boersma, Alethopter is lonchitica (Schlotheim) Sternberg, Cordaites spp., and Eremopteris spp. 
TABIE 1-Ranges of plant megali... oll occurring in near proximity withe Mississipplan-Pennsylvanian houndary in Southwestern Virginia and Southern West Virgina.

\section{I.YCOPODS \\ Lepidodendron aculeatum}

L. obovatum

L dicholomum

lepidofoyos sp.

Sugmaria ficoides

S. scellata

Ciperices bicarinatus

Lepidostrobophyllum spp.

SPHENOPSIDS

Calamiles radialus

(al. Archaeocalamites)

Mesocalamiles spp.

M. cistii

11. suckon'ii

Asterophyllites sp.

Asterophyllites longifolius

A. charaeformis

Annularia radiara

Calamosiachys sp.

Sphenophyllum tenerrimum

PTERIDOPHYLLS

Sphenopteris preslesensis

Alloiopteris coralloides

\section{PTERIDOSPERMS}

Sphenopteris elegans

Rhodeopteridium stachei

Sphenopteridium bifidum

Sphenopteris launoitii

s. portsvillea

Aneimires poltsvillensis

Archaeopteridium ischermackei

Liginopteris fragilis

$\angle$ bermudensiformis

Lhoeninghausii

Aneimites fertilis

A. tenuifolius

Eusphenopteris sp.

Enemopteris sp.

Palmatopteris furcata

"Alethopieris" parva

Alethopteris davreuxi

A. evansi

Veuropteris pocahonias

Mariopteris eremopteroides

Trigonocarpus sp.

\section{CORDAITES}

Cordaites sp.

Cordaites palmaeformis

Cordaianthus sp.

Cardiocarpon sp.
IPPIR MISSISSIPPIAN SERIES

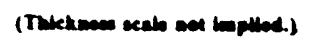$$
\text { ( }
$$

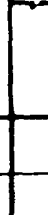
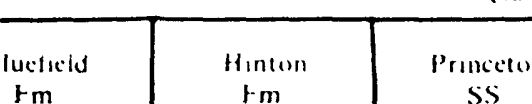

rinceton
SS
LOWER

PENNSYIVANIAN SERIES

$(-)$

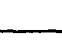

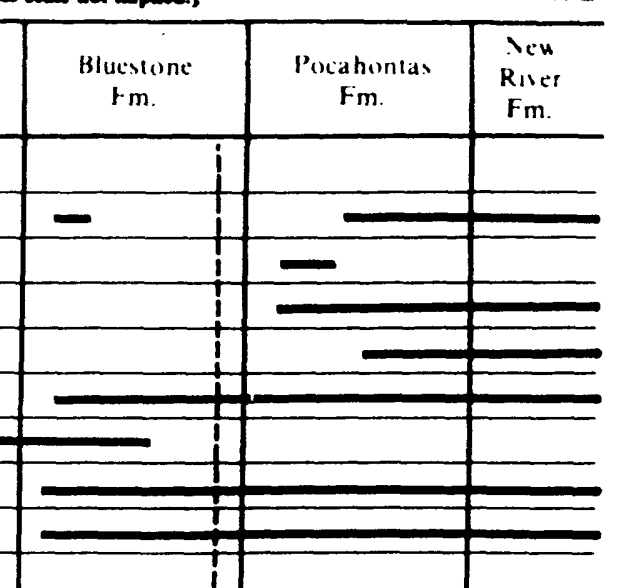

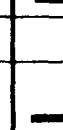

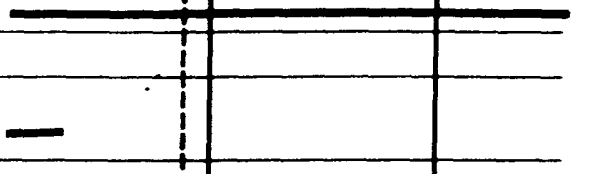

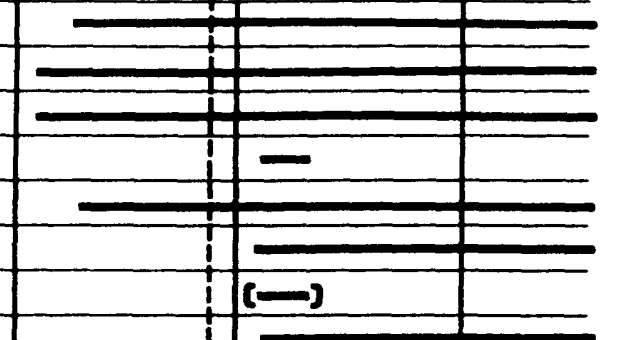

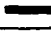
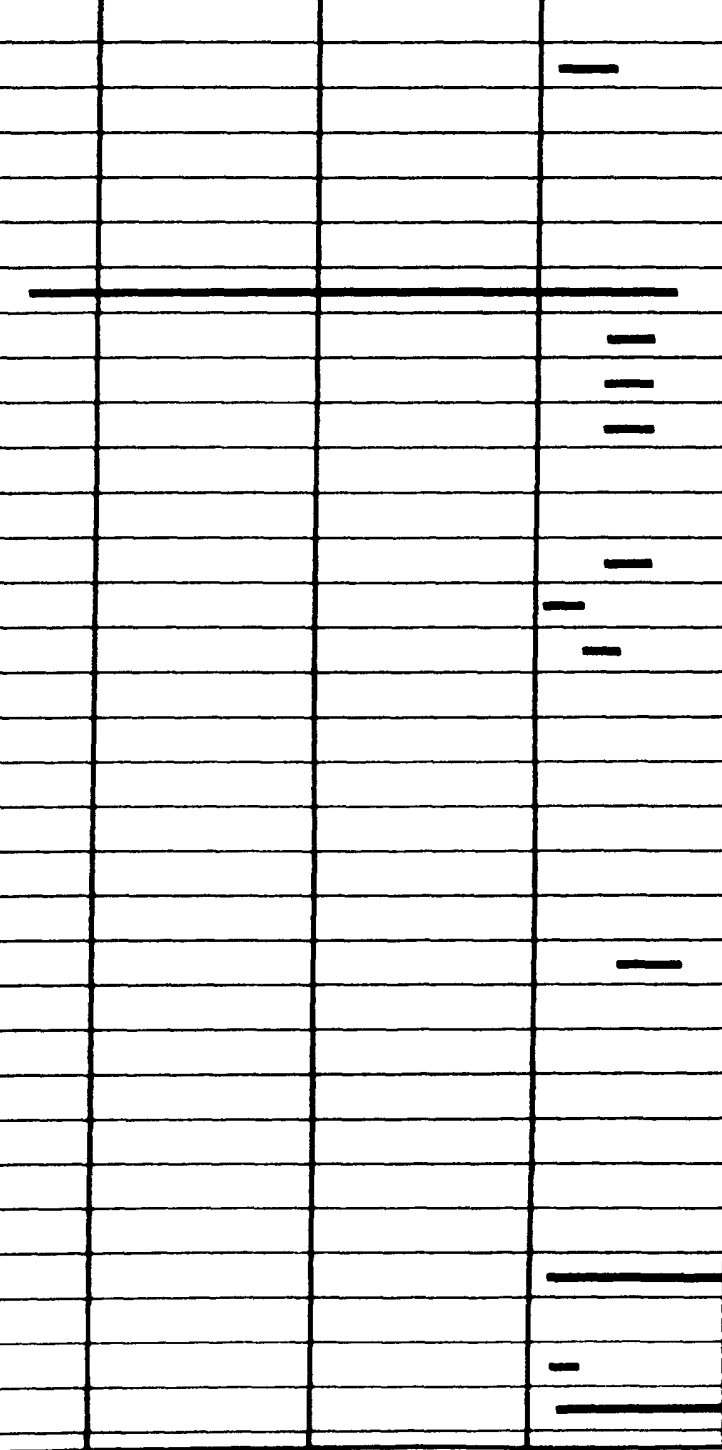

From Pfefferkorn and Gillespie. 1982 
Other species are locally abundant but not generally distributed throughout the column including Zeilleria delicatula Sternberg, Sphenophyllum tenue David White, Alethopteris decurrens (Artis) Zeiller, Diplothmena cheathami (Lesquereux) David White, Aneimites pottsvillensis David White, Palmatopteris furcata (Brongniart) Potonie, Eusphenopteris cf. aldrichi (D. White) Van Ameron, Annularia radiata (Brongniart) Sternberg, Asterophyllites equisetiformis (Sternberg) Brongniart and Alloiopteris georgiana Lesquereux.

Two collections, both as sociated with marine and marginal-marine invertebrates (Henry and others, 1981), were made in the type section of the Parkwood Formation near Birmingham, Alabama. The lower flora collected approximately $328 \mathrm{ft}$ above the base of the Parkwood Formation contains Pecopteris aspera Brongniart, Sphenophyllum tenerrimum Ettingshausen, and Sphenopteris elegens (Brongniart) Sternberg. The second flora collected near the top of the formation contains Neuropteris smithi Lesquereux. A third flora from near Isbell in northwestern Alabama was collected just above the Bangor Limestone and it contains Neuropteris pocahontas David White and Sphenopteris preslesensis Stockmans and Williere.

Rare to abundant plant megafossils were collected also from each of the eight coal groups in the Cahaba field, from the Howard in the Coosa field, and from the Cliff coal beds in the Plateau field. All of the collections are from outcrops and surface mines. In addition, several of the collections from the Warrior basin were taken from drill cores. These collections were sorted into three categories - (1) endemic and new species, (2) common long-ranging species of little stratigraphic significance, and (3) remaining species. Taxa with general ranges, at least within the Warrior basin include Sigillaria elegans Brongniart, Lepidodendron aculeatum Sternberg, L. obovatum Sternberg, Lepidophloios laricinus Sternberg, Asterophyllites charaeformis (Sternberg) Zeiller, Neuropteris pocahontas David White, N. smithi Lesquereux, N. hollandica Stockmans, Sphenopteris pottsvillea (David White) Gastaldo and Boersma, Mariopteris muricata (Schlotheim) Alethopteris valida Boulay, A. decurrens (Artis) Zeiller, A. lonchitica (Schlotheim) Sternberg, Paripteris gigantea (Sternberg) Gothan and Sphenopteris hoeninghausi (Brongniart) Potonie. Other species are locally abundant, but are not yet known to occur commonly throughout the section and a few species, such as Neuralethopteris larischi Susta, have been found thus far only at the Brookwood coal horizon. Additional collecting will, however, undoubtedly extend the ranges compiled during this preliminary survey.

\section{DISCUSSION}

The floral assemblages in the southern Appalachians are very similar to the assemblages found in Europe.

In Europe, Sphenopteris elegans ( $=$ S. adiantoides) is considered to be the index fossil for the Namurian A. Stigmaria stellata and sphenophyllum tenerrimum have slightly longer ranges, but both species occur most commonly in the Namurian $A$, and floras containing all three plants have not been found outside of this interval (Pfefferkorn and Gillespie, 1982). Consequently, the Bluestone Formation of Virginia and West Virginia correlates with the Namurian $A$ of western and central Europe. 
In Europe, the change in floras from the Namurian A to the Namurian $B$ is much more abrupt than the next older or next younger boundary. Gothan (1952) used the term "Florensprung" or "plant leap" to describe the abrupt appearance, of new genera and species at the base of the Namurian B. Several paleobotanists have questioned the appropriateness of Gothan's term because several species do transcend the boundary. However, the floral change between the Namurian A and $B$ is more clearcut than any other transitional stratigraphic boundary within the Carboniferous. This boundary is also recognizable in most regions having Carboniferous strata, so it is a valuable boundary for stratigraphic correlation. Bouroz and others (1978) suggested that this boundary be used for any major subdivision of the overall Carboniferous into subsystems. Havlena (1982) on the basis of extensive plant megafossil collections from the Ostrava-Karvina coal field suggested that the "Florensprung" at the Namurian A/B boundary (or H/R ammonoid superzone boundary) was caused by environmental, rather than tectonic changes. Wagner (1982a) generally accepted the boundary as a worldwide climatic event which probably had more immediate effects on the land plants than on marine faunas.

The Namurian B flora in Europe is characterized by Neuralethopteris schlehani (Stur) Cremer, Karinopteris acuta (Brongniart) Boersma and some Lyginopteris hoeninghausi (Brongniart) Potonie. These plants, or their equivalents, are also the dominant forms in the lower beds of the Pennsylvanian System in the area of the Pennsylvanian System stratotype section.

In Georgia, the occurrence of Archaeopteriduim tschermackei in the upper part of the Pennington Formation indicates that the strata are comparable in age (Namurian A or Late Mississippian) to the Bluestone Formation in Virginia and West Virginia.

In Alabama, collections from the lower part of the Parkwood Formation are virtually identical to those from the Bluestone Formation indicating relative age similarities between the two units. To date, other collections in the Mississippian of Alabama have not been made. As can be seen from the species listings, the plant compression floras from the Pennsylvanian of both Georgia and Alabama compare very favorably with those of the Westphalian A of Europe and with the Early, but not earliest, Pennsylvanian (probably New River) floras of the Pennsylvanian System stratotype section (fig. 4). These correlations are in general agreement with David White's conclusion (White, 1900) that the Pennsylvanian rocks of Georgia were of early Pottsville age when compared to West Virginia and Pennsylvania and that the No. 3 coal bed near Durham, Georgia is early, but not earliest, Pottsville (White, 1943). Later, Metzger (1965) reported that Read had determined the age of plants found above the Guide coal bed, the youngest known coal in the Warrior field of Alabama, to be latest Early Pennsylvanian (New River).

Analysis of the plant megafossils of Carboniferous age in Virginia-West Virginia has made it possible to suggest correlations with strata in other parts of the U.S. (Gillespie and Pfefferkorn, 1977, 1979a,b; Pfefferkorn and Gillespie, 1979, 1980, 1981b, 1982). Plants representative of the Bluestone flora have also been reported from the late Chesterian of Illinois (Jennings, 1970), the Wedington Sandstone of Arkansas (White, 1936), and from southern Nevada (Pfefferkorn, 1972). The flora of the Stanley Shale and Jackfork Sandstone of western Arkansas and southwestern Oklahoma was considered to be Early Pennsylvanian by David White (1937), but Read and Mamay (1964) believed it to be Late Mississippian. 
In summary, plant megafossils from above and below the lithologically established Mississippian-Pennsylvanian boundary in the Pennsylvanian System stratotype area indicate that the boundary coincides with the Namurian A-B boundary of western and central Europe. Similar floras have been identified in other parts of the United States and have proven to be useful for stratigraphic correlation.

It should be mentioned that although the plant megafossil assemblages of North America and western and central Europe correlate rather well, there are differences in the ranges of individual species. Some of the differences are undoubtedly due to more intensive collecting over a longer time span in Europe, but other range differences appear to be real. One example is Neuralethopteris larischi Susta. This species is very abundant above the Guide coal, the youngest coal in the Warrior basin of Alabama, but in Europe, this species begins in the Namurian $B$ and ends in the lowermost Westphalian $A$, a stratigraphic position lower than in the southern Appalachians. Another example is the occurrence of Sphenopteris hoeninghausi in West virginia at stratigraphically older horizons than in Europe, although Havlena (1982) does report occurrences of this species in the higher Namurian. These and other examples, such as the reported finding of a Permian type flora several hundreds of feet below typically Pennsylvanian floras (Moore and others, 1936) serve to emphasize the correctness of the statement by Wagner (1982b) that "It is a fact that the stratigraphic ranges of the individual species do not wholly coincide in the different areas and that some species (e.g., Senftenbergia aspera) show important discrepancies in this respect. It is also true that persistent collecting will tend to lengthen the stratigraphic ranges, particularly if sporadic occurrences are taken into account. Evolutionary changes are also bound to be gradual and only general considerations are likely to be valid when it comes to selecting boundaries on evolutionary criteria." 


\begin{tabular}{|c|c|c|c|c|c|}
\hline \multirow[t]{2}{*}{$\begin{array}{c}\text { EUROPEAN } \\
\text { STAGES }\end{array}$} & \multicolumn{2}{|c|}{$\begin{array}{c}\text { AREA OF } \\
\text { PENNSYLVANIAN } \\
\text { SYSTEM STRATOTYPE }\end{array}$} & \multirow{2}{*}{ 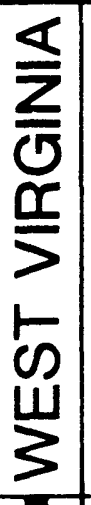 } & \multirow{2}{*}{ 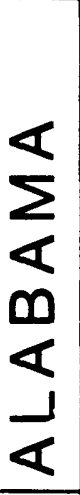 } & \multirow{2}{*}{$\begin{array}{l}\frac{\nwarrow}{\sigma} \\
\sigma \\
\ltimes \\
0 \\
w \\
\sigma \\
\end{array}$} \\
\hline & $\begin{array}{l}\text { GROUP OR } \\
\text { FORMATION }\end{array}$ & $\begin{array}{l}\text { SYSTEM OR } \\
\text { SERIES }\end{array}$ & & & \\
\hline AUTUNIAN & DUNKARD & PERMIAN & & & \\
\hline \multirow[t]{2}{*}{ STEPHANIAN } & MONONGAHELA & \multirow{2}{*}{$\begin{array}{c}\text { UPPER } \\
\text { PENNSYLVANIAN } \\
\text { SERIES }\end{array}$} & & & \\
\hline & CONEMAUGH & & & & \\
\hline WESTPHALIAN & $\begin{array}{l}\text { CHARLESTON } \\
\text { SANDSTONE }\end{array}$ & \multirow{2}{*}{$\begin{array}{c}\text { MIDDLE } \\
\text { PENNSYLVANIAN } \\
\text { SERIES }\end{array}$} & & & \\
\hline$\frac{C}{B}$ & KANAWHA & & & & \\
\hline$\frac{A}{C}$ & NEW RIVER & \multirow{2}{*}{$\begin{array}{c}\text { LOWER } \\
\text { PENNSYLVANIAN } \\
\text { SERIES }\end{array}$} & & \multirow[t]{2}{*}{ ? } & ? \\
\hline NAMURIAN & POCAHONTAS & & & & \\
\hline n & & $\begin{array}{c}\text { UPPER } \\
\text { MIS SISSIPPIAN } \\
\text { SERIES } \\
\end{array}$ & & & \\
\hline
\end{tabular}

Figure 4. Probable correlations as based on plant compression-impression megafossils, in the southern Appalachian basin. 


\title{
MIOSPORES IN PERTSYLVARIAN COAL BEDS OF THE SOUTHERR APPALACHIAR BASIR AID THEIR STRATIGRAPHIC IMPLICATIORS
}

\author{
Cortland F. Eble ${ }^{1}$, William H. Gillespie ${ }^{2}$, Thomas J. Crawford ${ }^{3}$, \\ and Lawrence J. Rheams 4
}

\section{ABSTRACT}

Fifty-one samples of coal and carbonaceous shale were collected in Alabama and Georgia from outcrops, surface mines, and drill cores. All 11 coal beds in the Pennsylvanian System in Georgia were sampled. Samples from the Warrior basin in Alabama were first collected from the Guide coal bed and from the $J$ coal group, respectively the youngest and oldest coal beds in the Pennsylvanian strata of that state. Subsequently, several samples were obtained from each of the eight major coal groups in the Warrior basin and from a few coal beds in the Cahaba basin.

The presence of the Schulzospora rara - Radiizonates striatus palynomorph assemblage indicates that all of the sampled strata are equivalent to the Westphalian A of Great Britain, Western Europe, and the Donetz basin; the Upper Morrowan of the Illinois basin; and the Lower Pennsylvanian of the Pennsylvanian System stratotype of Virginia and West Virginia.

\section{INTRODUCTION}

During Late Mississippian and Early Pennsylvanian time, the shallow, slowly subsiding Appalachian basin extended from Alabama, through eastern Tennessee, eastern Kentucky, southwestern Virginia, West Virginia, and into Pennsylvania. A continuous section across the Mississippian-Pennsylvanian boundary is present near the West Virginia-Virginia stateline, where the U.S. Geological Survey conducted the Pennsylvanian System stratotype study (Englund and others, 1977, 1979).

The study of the megaflora for the Pennsylvanian System stratotype project has been expanded to include the Carboniferous of the states of Tennessee, Georgia, and Alabama. Wherever possible, palynological studies have been made on these strata to confirm correlations (Gillespie and others, 1985a).

\section{PREVIOUS WORR}

Upshaw (1967) studied the miospores of the youngest Carboniferous rocks in Alabama. He reported that they were of Early Pennsylvanian age. He also reported that younger strata of lower Middle Pennsylvanian age (Kanawha) occurred in the subsurface of Mississippi. Wilson (1975) reported that spores from a coal bed in the Raccoon Mountain Formation of Alabama had "definite Chesterian" attributes.

\footnotetext{
Thest Virginia Geological Survey, Morgantown, WV 26506

2U.S. Geological Survey, 916 Churchill Circle, Charleston, WV 25314

3West Georgia College, Carrollton, GA 30117, and

${ }^{4}$ Geological Survey of Alabama, Drawer 0, University, Alabama 35486
} 
MATERIALS AND METHODS

Fifty-one samples of coal and carbonaceous shale were collected from strata of Pennsylvanian age in Alabama and Georgia. The Alabama samples were collected in conjunction with the cooperative coal quality sampling program of the United States and Alabama Geological Surveys and came from outcrops, surface mines, and deep coring programs. Those from Georgia were collected during an intensive geologic mapping program of several years duration by personnel of the United States Geological Survey.

The samples were carefully cleaned, ground to -20 mesh size, thoroughly mixed, and riffled. Five grams of the coal were then oxidized in Schultzes solution (concentrated nitric acid saturated with potassium chlorate), digested in 5 percent potassium hydroxide, washed several times and screened through a 210 micron mesh screen. The resulting "fine" residues (less than 210 microns) were concentrated in an acidified, saturated solution of zinc chloride and mounted on cover glasses with polyvinyl alcohol. Upon drying, the cover glasses were inverted and adhered to standard microscope slides with Permount.

The non-coal samples were prepared by eliminating the mineral matter with 10 percent $\mathrm{HCl}$ and concentrated $\mathrm{HF}$. The organic material was oxidized briefly with concentrated nitric acid, digested in 5 percent potassium carbonate, washed several times and screened through a 210 micron mesh screen. The resulting "fine" residues (less than 210 microns) were concentrated in an acidified, saturated solution of zinc chloride and mounted on slides using polyvinyl alocohol and Permount.

A total of 400 spores were counted from each maceration, 200 from each of two slides. The slides were then scanned for additional taxa which may have been overlooked during the statistical count.

Photographs were taken with a Nikon M-35-S camera using Kodak plus-X film. The maceration residues, slides, film negatives and extra coal are presently housed at the West Virginia Geological and Economic Survey, Morgantown, West Virginia.

\section{SYSTEMATIC PALYNOLOGY}

A total of 76 species assignable to 33 small genera were observed during the study. They are as follows:

Genus LEIOTRILETES (Naumova) Potonie and Kremp 1954

Leiotriletes cf. gulaferus Potonie and Kremp 1954

L. inermis (Wa1tz) Is chenko 1952

L. levis (Kosanke) Potonie and Kremp 1954

L. parvus Guenne1 1958

L. cf. sphaerotriangulus (Loose) Potonie and Kremp 1954

Genus PUNCTATISPORITES (Ibrahim) Potonie and Rremp 1954

Punctatisporites cf. irrasus Hacquebard 1957

P. minutus Kosanke 1950

P. nahannensis Hacquebard and Barss 1957

P. nitidus Hoffmeister, Stapl in and Malloy 1955

P. psuedolevatus Hof fmeister, Staplin and Malloy 1955

P. sinuatus (Artuz) Neves 1961

P. solidus Hacquebard 1957 
Genus CALAMOSPORA Schopf, Wilson and Bentall 1944

Calamospora microrugosa (Ibrahim) Schopf, Wilson and Bental1 1944

C. pallida (Loose) Schopf, Wilson and Bentall 1944

C. parva Guennel 1958

C. straminea Wilson and Kosanke 1944

C. breviradiata Kosanke 1950

Genus GRANULATISPORITES (Ibrahim) Potonie and Kremp 1954

Granulatisporites granulatus Ibrahim 1933

G. microgranifer Ibrahim 1933

G. pallidus Kosanke 1950

G. parvus (Ibrahim) Potonie and Kremp 1955

G. piroform is Loose 1934

Genus CYCLOGRANISPORITES Potonie and Kremp 1955

C. microgranus Bharadwaj 1957

C. minutus Bharadwaj 1957

Genus LOPHOTRILETES (Naumova) Potonie and Kremp 1954

Lophotriletes commissuralis (Kosanke) Potonie and Kremp 1955

L. cf. granoornatus Artuz 1957

L. microsaetosus (Loose) Potonie and Kremp 1955

Genus ANAPICULATISPORITES Potonie and Kremp 1954

Anapiculatisporites minor (Butterworth and Williams) Smith and But terworth 1967

Genus ANAPLANIS PORITES Jansonius 1962

Anaplanisporites baccatus (Hoffmeister, Staplin and Malloy) Smith and Butterworth 1967

Genus APICULATISPORIS Potonie and Rremp 1956

Apiculatisporis abditus (Loose) Potonie and Kremp 1955

A. aculeatus (Ibrahim) Smith and butterworth 1967

A. cf. latigranifer (Loose) Potonie and Kremp 1955

A. setulosus (Kosanke) Potonie and Kremp 1955

A. spinosaetosus (Loose) Smith and Butterworth 1967

A. variocorneus Sullivan 1964

Genus PLANISPORITES (Knox) Potonie 1960

Planisporites granifer (Ibrahim) Knox 1950

Genus APICULATISPORITES (Ibrahim) Smith amd Butterworth 1967

Apiculatisporites spinulistratus (Loose) Ibrahim 1933

Genus ACANTHOTRILETES (Naumova) Potonie and Kremp 1954

Acanthotriletes aculeolatus (Kosanke) Potonie and Kremp 1955

A. echinatus (Rnox) Potonie and Kremp 1955

Genus RAISTRICKIA Schopf, Wilson and Bental1 1944

Raistrickia fulva Artuz 1957

R. saetosa (Loose) Schopf, Wilson and Bentall 1944

Genus CONVOLUTISPORA Hoffmeister, Staplin and Malloy 1955

Convolut ispora sp. 
Genus MICRORETICULATISPORITES (Knox) Potonie and Kremp 1954

Microreticulatisporites cf. nobilis (Wicher) Knox 1950

Genus DICTYOTRILETES (Naumova) Smith and Butterworth 1967

Dictyotriletes reticulocingulum (Loose) Smith and Butterworth 1967

Genus CAMPTOTRILETES (Naumova) Potonie and Kremp 1954

Camptotriletes bucculentus (Loose) Potonie and Kremp 1955

C. corrugatus (Ibrahim) Potonie and Kremp 1955

Genus AHRENSISPORITES Potonie and Kremp 1954

Ahrensisporites guerickei (Horst) Potonie and Kremp 1954

Genus REINSCHOSPORA Schopf, Wilson and Bental1 1944

Reinschospora cf. triangularis Kosanke 1950

Genus STENOZONOTRILETES (Naumova) Potonie 1958

Stenozonotriletes cf. Iycosporoides (Butterworth and Williams) Smith and Butterworth 1967

Genus KNOXISPORITES (Potonie and Kremp) Neves and Playford 1961

Knoxisporites triradiatus Hoffmeister, Staplin and Malloy 1955

Genus GRUMOSISPORITES Smith and Butterworth 1967

Grumosisporites varioreticulatus (Neves) Smith and Butterworth 1967

Genus CRASSISPORA (Bharadwaj) Sullivan 1964

Crassispora kosankei (Potonie and Kremp) Bharadwaj 1957

Genus DENSOSPORITES (Berry) Butterworth, Jansonius, Smith and Staplin 1964

Densosporites annulatus (Loose) Smith and Butterworth 1967

D. granulosus Kosanke 1950

D. pseudoannulatus Butterworth and Williams 1958

D. cf. sphaerotriangularis Kosanke 1950

D. $s p$.

Genus LYCOSPORA Schopf, Wilson and Bentall 1950

Lycospora granulata Kosanke 1950

L. micropapillata (Wilson and Coe) Schopf, Wilson and Bentall 1944

L. pellucida (Wicher) Schopf, Wilson and Bentall 1944

L. noctuina Butterworth and Williams 1958

L. torquifer (Loose) Potonie and Kremp 1955

Genus CRISTATISPORITES (Potonie and Kremp) Butterworth, Jansonius, Smith and Staplin 1964

Cristatisporites indignabundus (Loose) Staplin and Jansonius 1964

Genus CIRRATRIRADITES Wilson and Coe 1940

Cirratriradites saturni (Ibrahim) Schopf, Wilson and Bental 11944

Genus CINGULIZONATES (Dybova and Jachowicz) Butterworth, Jansonius, Smith and Stapl in 1964

Cingulizonates loricatus (Loose) Butterworth and Smith 1964 
Genus RADIIZONATES Staplin and Jansonius 1964

Radiizonates aligerens (Knox) Staplin and Jansonius 1964

R. Striatus (Knox) Staplin and Jansonius 1964

Genus SCHULZOSPORA Kosanke 1950

Schulzospora rara Kosanke 1950

Schulzospora sp.

Genus LAEVIGATOSPORITES Ibrahim 1933

Laevigatosporites minimus (Wilson and Coe) Schopf, Wilson and Bentall 1944

L. minor Loose 1934

L. vulgaris Ibrahim 1933

Genus PUNCTATOSPORITES Ibrahim 1933

Punctatosporites minutus Ibrahim 1933

Genus FLORINITES Schopf, Wilson and Bentall 1944

Florinites florini Imgrund 1960

F. mediapudens (Loose) Potonie and Kremp 1956

F. pumicosus (Ibrahim) Schopf, Wilson and Bentall 1944

\section{CONCLUSIONS}

Thiessen and Staud (1923) and Thiessen and Wilson (1924) are generally recognized as the first scientists to use fossil plant spores for coal bed correlation. In the succeeding years, thousands of scientific contributions have produced a wealth of data on the stratigraphic distribution of miospores. However, because of paleolatitudinal variations in the parent flora and differences in the sedimentary environments, it has proven difficult to develop zonation schemes for interregional correlations. A palynological zonation has not been developed for North America. Smith and Butterworth (1967), however, have published a miospore zonation for the Carboniferous of Great Britain; Owens (1984) for the Carboniferous of the western Europe - Donetz Basin region; and Lianda (1984) for the Carboniferous of China. Peppers (1984) has compared the miospore assemblages in the Pennsylvanian System of the Illinois Basin with those found in the Upper Carboniferous of western Europe.

A comparison of the miospore assemblages found in this preliminary study of the Pennsylvanian strata of Alabama and Georgia ( $f$ ig. 5) with the Owens zonation indicates that the strata are equivalent to the Westphalian $A$ of the Donetz Basin and western Europe. The same relative age is indicated when our data are compared with the Smith and Butterworth zonation. In Illinois, the equivalent strata are in the Caseyville Formation of the Morrowan Series, which is also equivalent to the Westphalian A. A comparison with the Pennsylvanian System stratotype section indicates that the strata probably are equivalent to part of the New River Formation which is Westphalian A.

Palynological data are not yet complete for all of the Lower Pennsylvanian strata found in the Pennsylvanian System stratotype section. Consequently, the base of the Westphalian $A$ has not yet been precisely established through palynological means. Samples are presently being collected that may help to resolve this problem. 
1) Lycospora pellucida (Wicher) Schopf, Wilson and Bental1 1944, 42 x $35.6 \mathrm{u}$

2) Lycospora granulata Kosanke $1950,33.2$ × $24 u$

3) Lycospora pusilla (Ibrahim) Schopf, Wilson and Bental1 1944, $24.6 \times 24 \mathrm{u}$

4) Punctatosporites minutus Ibrahim 1933, 24.4 x $17.2 \mathrm{u}$

5) Punctatisporites minutus Kosanke $1950,28.2 \times 23.6 \mathrm{u}$

6) Granulatisporites piroformis Loose $1934,27.2 \times 25.6 \mathrm{u}$

7) Granulatisporites parvus (Ibrahim) Potonie and Kremp 1955, 34 x $34 \mathrm{u}$

8) Leiotriletes levis (Kosanke) Potonie and Kremp 1955, 40 × 42u

9) Lophotriletes commissural is (Kosanke) Potonie and Kremp 1955, 29.2 x 26u

10) Acanthotriletes aculeolatas (Kosanke) Potonie and Kremp 1955, 29.6 x 28u

11) Apiculatisporis variocorneus Sullivan 1964,88 x 80u

12) Calamospora microrugosa (Ibrahim) Schopf, Wilson and Bentall 1944, $60.6 \times 52 u$

13) Calamospora breviradiata Rosanke $1950,52.6 \times 47 \mathrm{u}$

14) Punctatisporites sinuatus (Artuz) Neves $1961,102 \times 94 \mathrm{u}$

15) Densosporites cf. sphaerotriangularis Kosanke 1950, 46 x $46 \mathrm{u}$

16) Radiizonates striatus (Rnox) Staplin and Jansonius 1964, 44 x $47.2 \mathrm{u}$

17) Cristatisporites indignabuhdus (Loose) Stapl in and Jansonius 1964, $59.2 \times 40 u$

18) Schulzospora rara Kosanke $1950,79.4 \times 59.8 \mathrm{u}$

19) Ahrensisporites guerickei (Horst) Potonie and Kremp 1954, 51.6 x 49u

20) Crassispora kosankei (Potonie and Kremp) Bharadwaj 1957, 62 x $41.6 \mathrm{u}$

21) Grumosisporites varioreticulatus (Neves) Smith and Butterworth 1967 , $79.8 \times 66 u$

22) Florinites mediapudens (Loose) Potonie and Kremp 1956, 46 x 44u

23) Calamospora parva Guennel 1958, $30 \times 28 \mathrm{u}$

24) Lycospora noctuina Butterworth and Williams 1958, $36.2 \times 35.4 \mathrm{u}$ 
Figure 5. Lower Pennsylvanian miospores. page 27 folli $^{l i}$
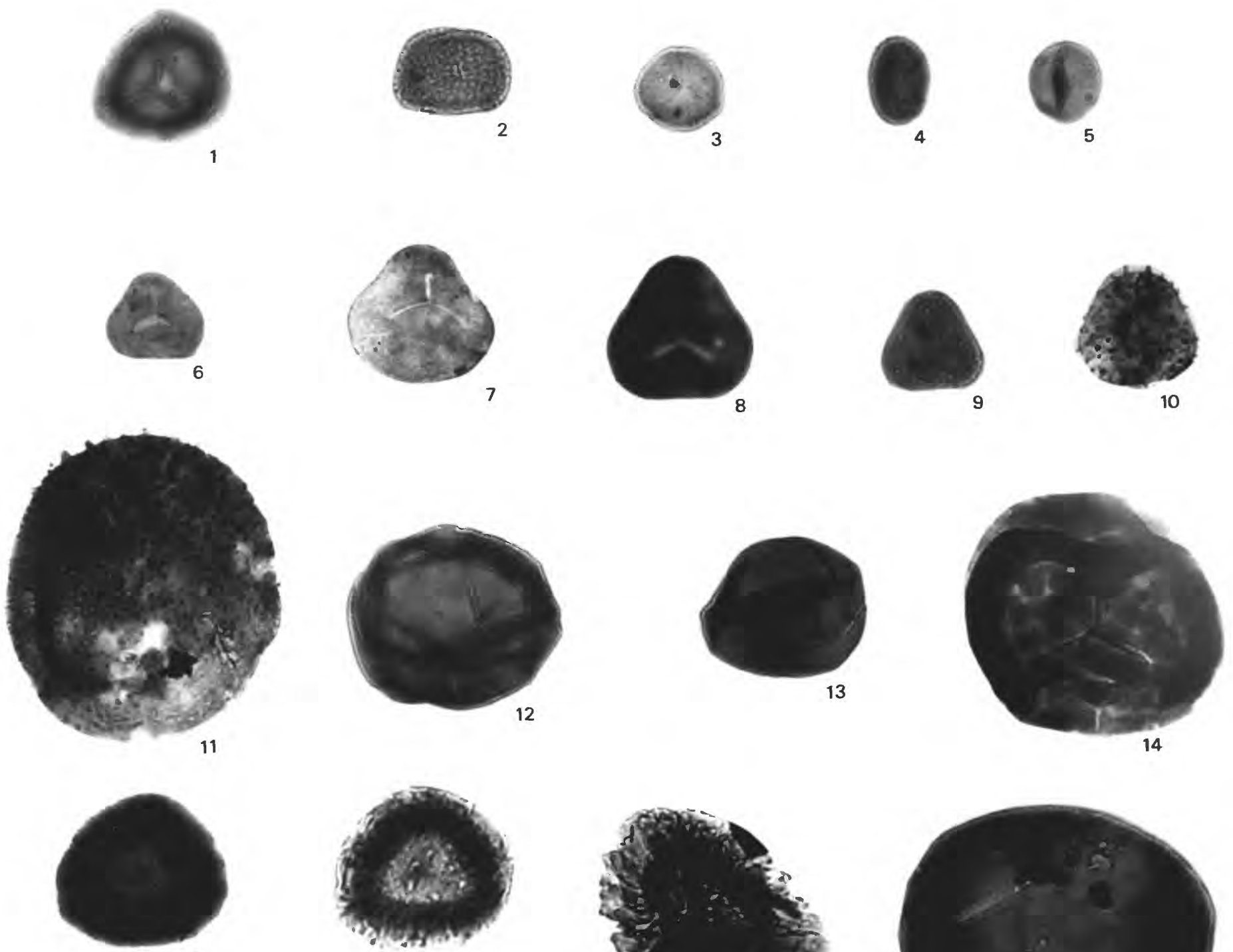

15
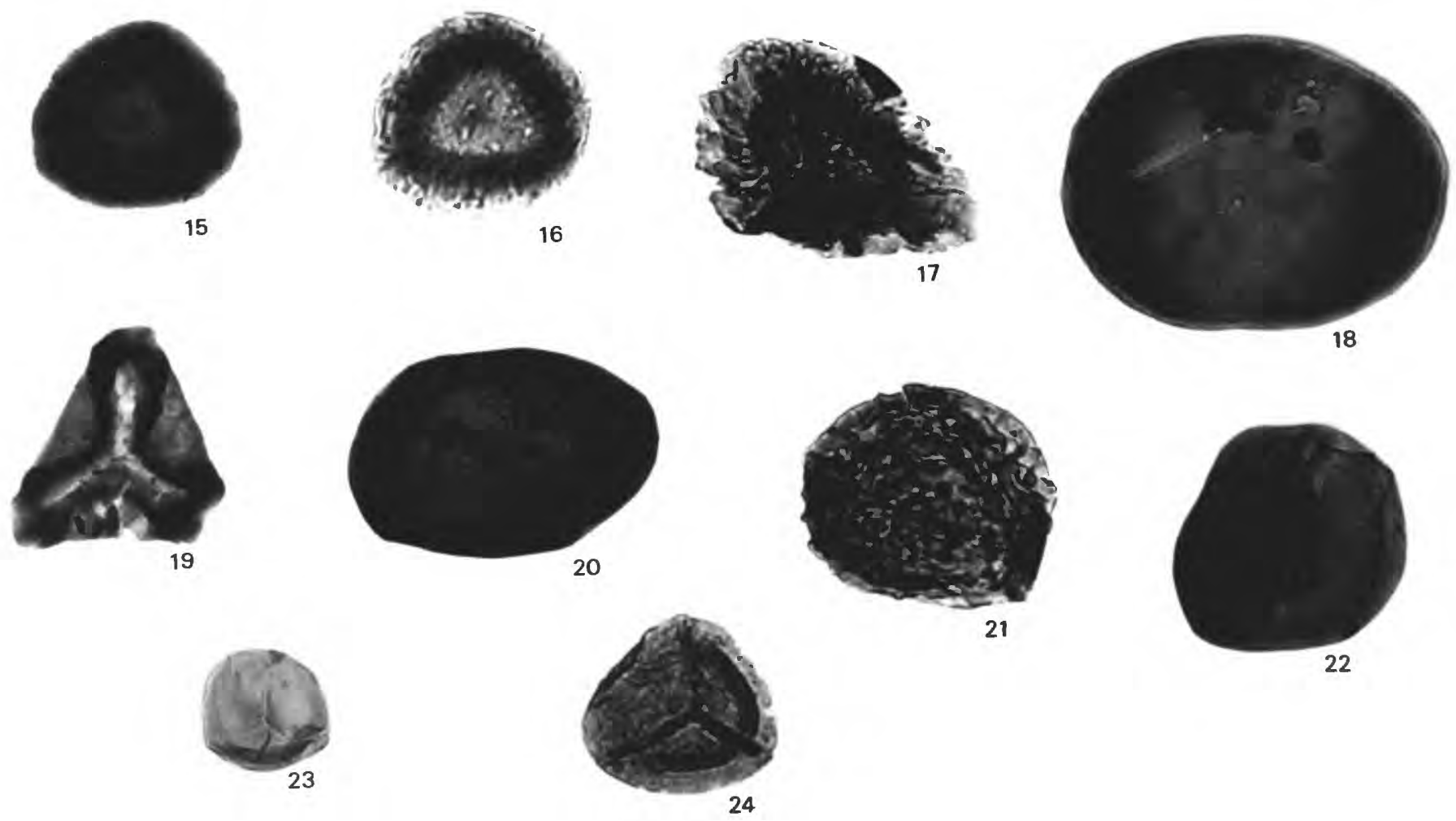

25

page 27 follows 


\title{
GEOLOGIC COImROLS ON SEDIMGTTATION AID PEAT FORMTION IN THE CARBONIFEROUS OF THB APPAIACHLAN BASIN
}

\author{
C. Blaine Cecil 1 and Kenneth J. Englund 1
}

\section{INTRODUCTION}

The occurrence of coal and associated strata in the Appalachian basin was controlled stratigraphically and regionally by many factors including both autocyclic and allocyclic processes of sedimentation. The evolution of land plants, first known from the silurian, was one of the initial controlling factors. Plants were well developed and contributed to a few minor coal deposits by Late Devonian time. Land plants flourished in Early Mississippian time as coal-forming environments became more common. Lower Mississippian coal has been mined near Blacksburg, Virginia. Thus, the availability of land plants was no longer a limiting factor in coal formation after the beginning of the Mississippian Period. However, these Mississippian coal deposits are very 1 imited in North America even though plants were available and depositional enviromments such as delta plains, coastal plains, and fluvial systems were common. Coal formation, therefore, must have been controlled by additional factors including allocyclic processes such as eustacy, tectonics, and climate and autocyclic processes such as delta switching.

Although the factors that control the occurrence and quality of coal are well known, criteria for an integrated evaluation of all factors are lacking. It is the purpose of this paper to present a genetic framework for the origin of coal deposits and associated rocks. We will attempt to classify and qualify the impact of various factors on the occurrence and quality of coal beds. The conceptual framework is based on the autocyclic and allocyclic processes of sedimentation (Beerbower, 1964). Beerbower's definition of these processes utilized the energy derived from fluvial systems in an attempt to transform the descriptive cyclothemic concept of Weller (1930) and Wanless (1946) into a quantitative, process oriented, model of sedimentation. Allocyclic and autocyclic are used herein to indicate the dominent energy sources in depositional systems although in a somewhat broader context than Beerbower's (1964) original definition. Allocyclic processes are driven by energy changes external to the system such as eustatic changes in sea level, tectonic activity, and climate changes. Autocyclic processes are those that are governed by the energy of the system such as delta switching and stream meandering. The present study suggests that the major coal beds of the Pennsylvanian were primarily controlled by allocyclic processes of climate, eustacy, and perhaps tectonic activity, whereas the thin, discontinuous, and impure coal beds can be attributed to autocyclic process of sedimentation. Busch and Rollins (1984) suggested that rocks of Carboniferous age can be "described, interpreted, and correlated using six scales of allocyclic transgressive-regressive (T-R) units." Clearly, there are transgressiveregressive units present in the Carboniferous of the Appalachian basin which cannot be explained by autocyclic processes. However, our data indicate that sedimentation and peat formation were also influenced by the paleoclimate, tectonics, and eustatic changes in sea level.

T.S. Geological Survey, Reston, Virginia 22092 
Many studies of coal formation tend to focus on recognizable attributes of rocks associated with coal beds, such as their depositional environments. However, predictive models that are based on single factors are generally inadequate predictors of either the occurrence or quality of the coal. In the Appalachian basin, delta-plain models are used often to predict coal bed continuity but they are not always successful because autocyclic processes such as delta switching cannot account for the spatial form and lateral continuity of the major coal beds. The conditions that are necessary for the formation of high-quality peat are inverse to the conditions that are necessary for the formation of fluvial-dominated deltas. Large-scale peat formation requires both low suspended- and dissolved-sediment loads, and large, flat areas that are uninterrupted by contemporaneous clastic sedimentation and associated channels. Therefore, fluvial-dominated deltaic systems are not conducive to the formation of high-quality coal beds because of high sediment influx and the lack of a suitable surface for extensive peat formation. This premise does not preclude the presence of rocks derived from fluvial-dominated deltaic sedimentation in the Pennsylvanian System of the Appalachian basin. It states only that the major stages of peat formation were not contemporaneous with fluvial-dominated deltaic sedimentation. Instead, we propose that the primary controls on major stages of peat formation are allocyclic processes involving paleoclimate, eustatic changes in sea level, and tectonics. These allocyclic processes account for the abundance of coal resources in Pennsylvanian rocks and the 1 imited occurrence of economically important coal deposits in rocks of Mississippian age. Coal beds that formed in response to autocyclic processes are generally thin, discontinuous, and of low quality. Secondary controls, such as the geochemistry of sedimentary environments, may be affected by both autocyclic and allocyclic processes. The object of this paper is therefore to present preliminary evidence in support of allocyclic processes as one of the primary controls on the deposition of major 1ithostratigraphic units and on the occurrence and quality of coal beds in rocks of Carboniferous age in the Appalachian basin.

\section{THE ALLOCYCLIC EFFECTS OF CLIMATE}

The importance of climate on coal formation is well known. Major Holocene peat deposits occur in everwet-tropical and cold-temperature regions of the world where rainfall is high relative to evapotranspiration. These modern peat deposits are found in exceedingly diverse enviromental settings, ranging from the coastal plains of Borneo and Sumatra to blanket-peat deposits on upland slopes in Scotland and the South Island of New Zealand. Modern deposits such as these are primarily controlled by the allocyclic processes. In Borneo and Sumatra, these processes include both eustacy and an everwet, tropical climate. In Scotland and New Zealand, rainfall, high humidity, and relatively low evapotranspiration allow blanket-peat deposits to form even on upland slopes. Peat formation in these diverse geologic and geographic settings clearly require more explanation than can be provided by an interpretation of the physical depositional environment.

Climate was apparently a primary control on peat formation during the Carboniferous, also. On the basis of plant megafossil data, White (1925) suggested that the climate of the Late Mississippian was arid or semiarid. In contrast, the climate of the Pennsylvanian was described as humid tropical or sub-tropical and equable except during the late Middle and Late Pennsylvanian 
when it was seasonal, according to White (1925). The limited occurrence of coal in the red-bed sequences of the Upper Mississippian and the Conemaugh Formation of the Upper Pennsylvanian Series may have been the result of a relatively dry climate. Phillips and Peppers (1984) have also related the abundance of coal resources in the Pennsylvanian of the Appalachian and Illinois basins to paleoclimate.

Major stratigraphic changes in the occurrence and quality of coal beds in the Carboniferous in the Appalachian basin has been attributed to variations in the geochemistry of nommarine-depositional environments, and the geochemistry, in turn, was controlled by paleoclimate (Cecil and others, 1985). The occurrence of low-sulfur $(\langle 1 \%)$ and low-ash $(<10 \%)$ coal beds in rocks of the Lower and lower Middle Pennsylvanian Series was attributed to oligotrophic, ombrogenous, conditions of peat formation that resulted in domed peat deposits in a tropical ever-wet climate. The seasonal climate of late Middle and Late Pennsylvanian time resulted in mesotrophic to eutrophic, topogenous peat deposits; these are the higher ash $(>10 \%)$ and higher sulfur $(>1 \%)$ coal beds of the upper Middle and Opper Pennsylvanian Series (Cecil and others, 1985).

The extent of major coal beds in the Pennsylvanian is indicative of peat formation over a large area such as the coastal lowlands of the Sunda shelf (Borneo, Sumatra, and the southern part of the Malay peninsula) (fig. 6). A major change in an allocyclic condition, such as sea level or climate, would probably terminate peat formation. The Pocahontas No. 3 coal bed represents an example of the effects of climate and eustacy. Cecil and others (1985), attributed the spatial form of the Pocahontas No. 3 to domed peat deposits in a coastal plain environment analogous to the modern coastal environments of Borneo and Sumatra: The paleoclimate was inferred to be ever-wet tropical based on coal quality data, the spatial form of the coal bed, and the type and amount of syngenetic and early diagenetic minerals in rocks associated with the coal bed. Englund (1974) has related the thick Pocahontas coal to peat formation on abandoned delta lobes. This interpretation was expanded to include peat formation on abandoned delta lobes during stillstands in sea level (Englund and others, 1984). On the basis of the two data sets we now suggest that the Pocahontas No. 3 coal bed is the result of allocyclic processes including climate and eustacy. The climate was ever-wet tropical and sea level was such that peat could form on a broad, flat coastal plain. Initial stages of peat formation commenced on the topographically high areas of abandoned delta lobes. Widespread, but locally domed deposits developed in the final stages of peat formation ( $\mathrm{fig} .7$ ).

Further indications of the paleoclimate of the Carboniferous can be found in the composition of clastic sediments. On the west side of the Appalachian basin, al umina-rich clay deposits (flint clay) are well developed on the Mississippian surface in Rentucky, Ohio, and Pennsylvania. Similar deposits are also fairly common in rocks of the upper Middle Pennsylvanian Series in Pennsylvania, West Virginia, Maryland, and Ohio. Quartzose sandstone deposits are common commencing in the Upper Mississippian, and extending into the Lower Pennsylvanian. The alumina-rich clay deposits, and perhaps the sandstone, may indicate tropical weathering. The clay deposits are residual (Patterson and Hosterman, 1962; Donaldson and others, 1985; Cecil and others, 1985) and the quartzose sandstone may be reworked weathering products (Cecil and others, 1985). Reworking of the sandstones is indicated in a nearshore marginal marine environment (Englund, 1974; Miller, 1974). 


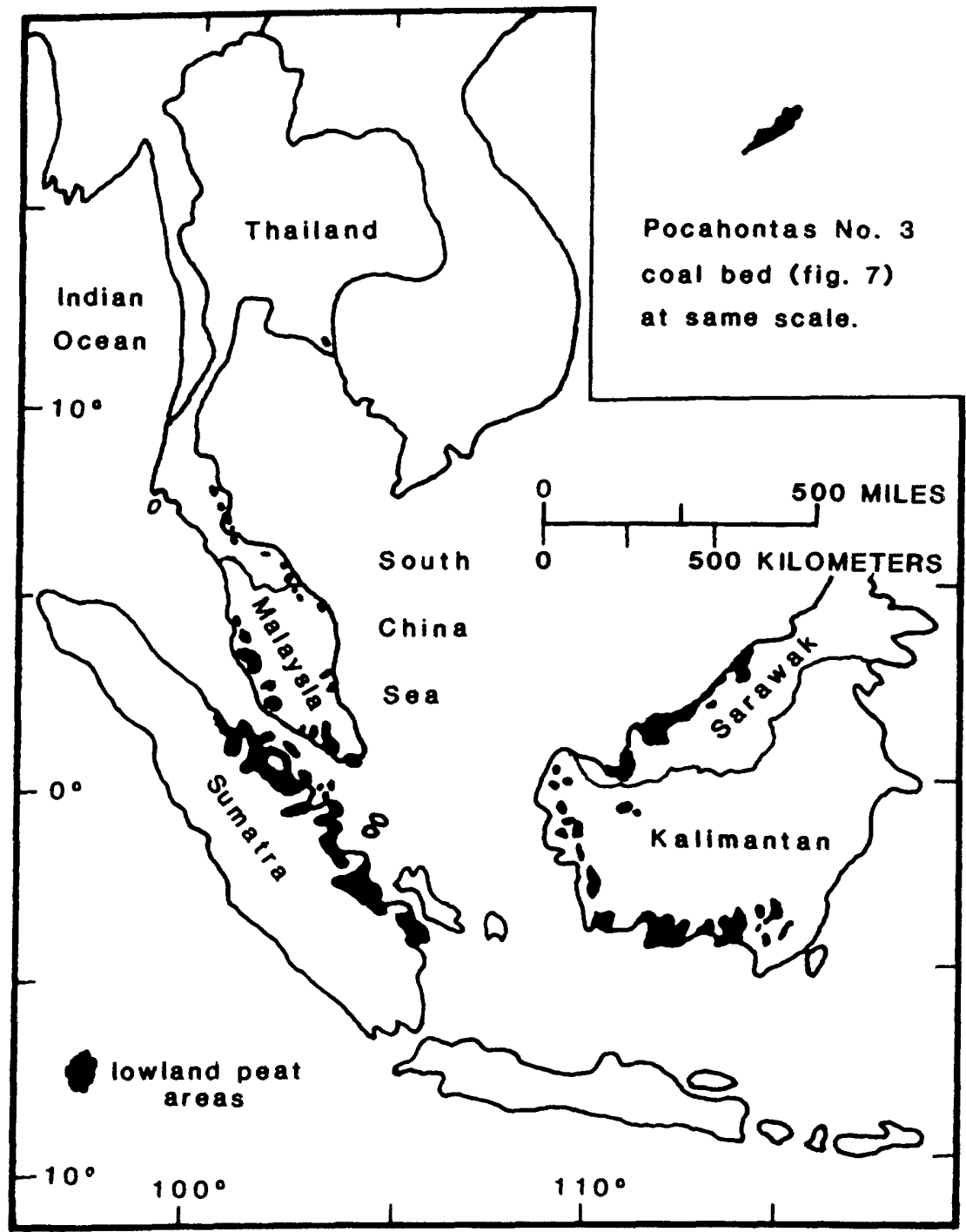

Figure 6. Distribution of tropical lowland peats in southeast Asia. 


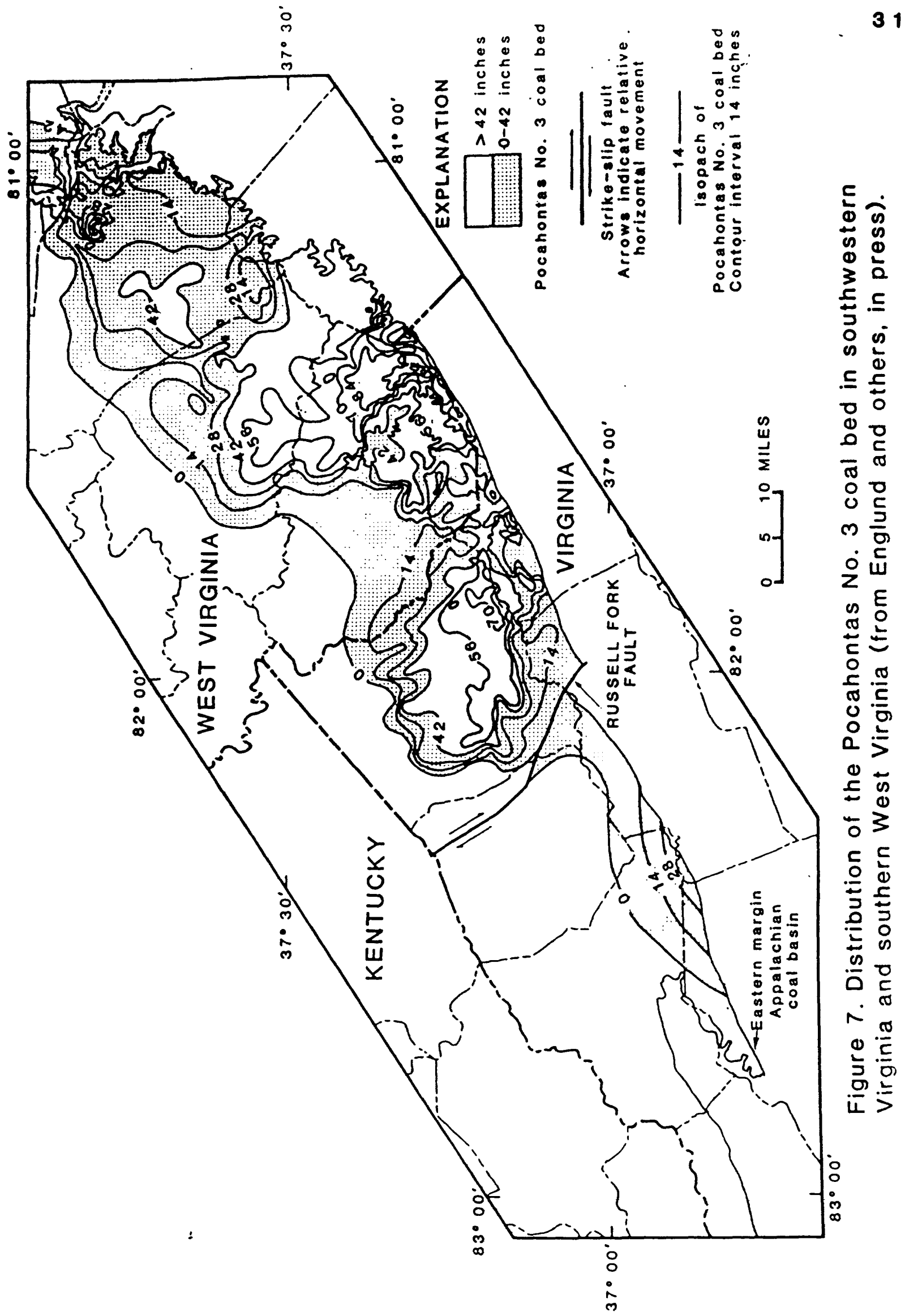


The dearth of heavy minerals in the quartzose sandstone may also be indicative of conditions of weathering and paleoclimate. Acid conditions of tropical weathering, which could produce a quartz residium, would tend to leach and destroy the heavy minerals. Minerals such as tourmaline, illmenite, magnetite, and perhaps even zircon, would not be stable in such an environment.

Syngenetic and early diagenetic minerals in rocks of nommarine origin are indicators of the geochemistry of depositional environment. The geochemistry of a nonmarine depositional environment is in part controlled by climate. These minerals include the oxides of iron, the carbonates, and the sulfides. Ever-wet tropical climates produce surface and near surface waters that are mildly acid and extremely low in dissolved solids. The dissolved solid content of the Amazon River is $28 \mathrm{mg} / 1$, and the $\mathrm{pH}$ is 6.5 (Hem, 1970). Stable minerals that could form under these conditions would include siderite under reducing conditions. Under drier climatic conditions, surface and near surface waters are more nearly neutral to mildly alkaline because of hydrolysis. They are also relatively high in dissolved solid content. The dissolved solid content of the Mississippi River is $256 \mathrm{mg} / 1$ (an order of magnitude greater than the Amazon) and the $\mathrm{pH}$ is 7.5 (Hem, 1970). Calcite may form and is stable; pyrite and siderite can form depending on oxidation/reduction conditions. Clear patterns exist in these syngenetic and early diagenetic minerals in nonmarine rocks of the Carboniferous. Calcite and hemitite are common in the grayishred beds of the Upper Mississippian Series. Paleosols that contain calcareous nodules are common. The combination of calcite and hemitite are indicative of water conditions that can be expected from a dry or seasonally dry climate. In the Lower Pennsylvanian sequence, calcite is rare and it is only associated with rocks of marine origin. Siderite is the predominant carbonate and ironbearing mineral. The lack of calcite and the abundance of siderite are indicative of a major change in water chemistry. This change has been attributed to a major paleoclimatic change in latest Mississippian or earliest Pennsylvanian time and the syngenetic and early diagenetic minerals in the rocks of the Lower Pennsylvanian are probably the result of an ever-wet tropical climate (Cecil and others, 1985). The water chemistry regime was also conducive to the formation of low-ash and low-sulfur coal.

\section{ALLOCYCLIC EFFECTS OF EUSTACY AND TECTONICS ON SEDIMENTATION AND DEPOSITIONAL ENVIRONMENTS}

It is not possible to separate the effects of eustatic change in sea level from subsidence on the basis of currently available data. The effects of sea level change on sedimentation may be independent of the cause of that change. However, throughout the Carboniferous there is evidence which indicates that eustatic changes in sea level did occur and surely the basin was subsiding to accommodate a thick sequence of shallow water sediments. For example, the widespread distribution of the Upper Mississippian limestone in the Appalachian basin and mid-continent area may be related to eustatic changes in sea level; the very thick sequence of Upper Mississippian 1 imestone in the east-central Appalachian basin may be related to differential subsidence. We will discuss eustacy and tectonics independently, although we recognize that at certain times they may have acted independently and at other times they may have acted synergistically.

On the basis of sedimentary structures and lithostratigraphy, we suggest that major changes in lithostratigraphic units are mainly the result of allocyclic processes; minor changes within the major lithostratigraphic units are the result of autocyclic processes. 


\section{THE ORIGIN OF QUARTZ ARENITES}

The origin of the quartz arenites in the Upper Mississippian and Lower Pennsylvanian Series has been the subject of a considerable amount of study. Interpretations generally favor either a beach-barrier origin (Englund, 1974; Miller, 1974; Ferm and others, 1971) or a braided-stream, fluvial origin (Donaldson and Schumaker, 1979; Houseknecht, 1980; Rice, 1984). The question of origin remains unresolved, largely because the data are not totally definitive and there are elements of both beach-barrier and fluvial systems in all data sets. We propose that the quartz arenites are primarily the results of tidally dominated systems. The tidal systems developed in response to the allocyclic processes of eustacy and/or tectonic activity. Rocks of tidal origin include estuarine, tidal flat, channel, and bay deposits. Quartzose sandstone of fluvial or beach-barrier origin are subdominant and they tend to be restricted to the margins of the major sandstone bodies. Sandstone beds of fluvial origin occur as channel fill deposits in fluvial channels that were supplying quartz sand and gravel to the tidal systems. Sandstone of beach-barrier origin may occur in those restricted areas where wave energy was dominant over tidal energy.

Evidence for tidal conditions includes both sedimentary structures and lithostratigraphic relationships. There are a number of mappable quartzose sandstone beds of Late Mississippian age in southeastern West Virginia and southwestern Virginia. These include the Stony Gap, Falls Mills, and Tallery Sandstone Members of the Hinton Formation and a few unnamed sandstone units. The basal contacts are erosional except near the margins where they may be gradational. The margin areas, and locally the basal part of these sandstones, are ripple bedded. The ripple bedding almost always contains herringbone structures of uniform thickness. This bidirectional crossbedding is highly indicative of deposition by tidal currents. Where the sandstone units reach their maximum thickness, they may be conglomeratic, and the ripple bedding generally grades upward into unidirectional, large-scale crossbeds that appear to be the result of accreting sand waves and/or megaripples, and migrating bars. Herringbone structures and flaser bedding or ripple bedding may occur again in the upper parts of the sandstone. The crossbedding suggests that the initial deposition of sand was the result of deposition by bidirectional currents in a subtidal to intratidal depositional environment near the marginal areas of the sand deposition. In the more central areas of deposition, stronger currents prevailed and a southwesterly flow direction was dominant. Flood-tide and ebb-tide currents in modern environments, such as the straits of Malacca on the Sunda shelf (Coleman and others, 1970; Reller and Richards, 1967) are on the order of 2.5 and $5 \mathrm{ft} / \mathrm{sec}$ respectively. Current velocities of this magnitude are adequate to transport coarse sand to fine gravel.

Sandstone such as the orthoquartzites of the Upper Mississippian and Lower Pennsylvanian may be the result of tidal deposition during sea level rise. Because this sandstone was deposited in a high-energy tidal environment, body fossils and trace fossils are extremely rare except in the marginal parts of the system. As sea level continues to increase, tidal energy was no longer channelized and sedimentation changed. Lower energy tidal deposits are indicated by units such as the Pride Shale Member of the Bluestone Formation and flaser-bedded clastics of the Lower Pennsylvanian Series. 


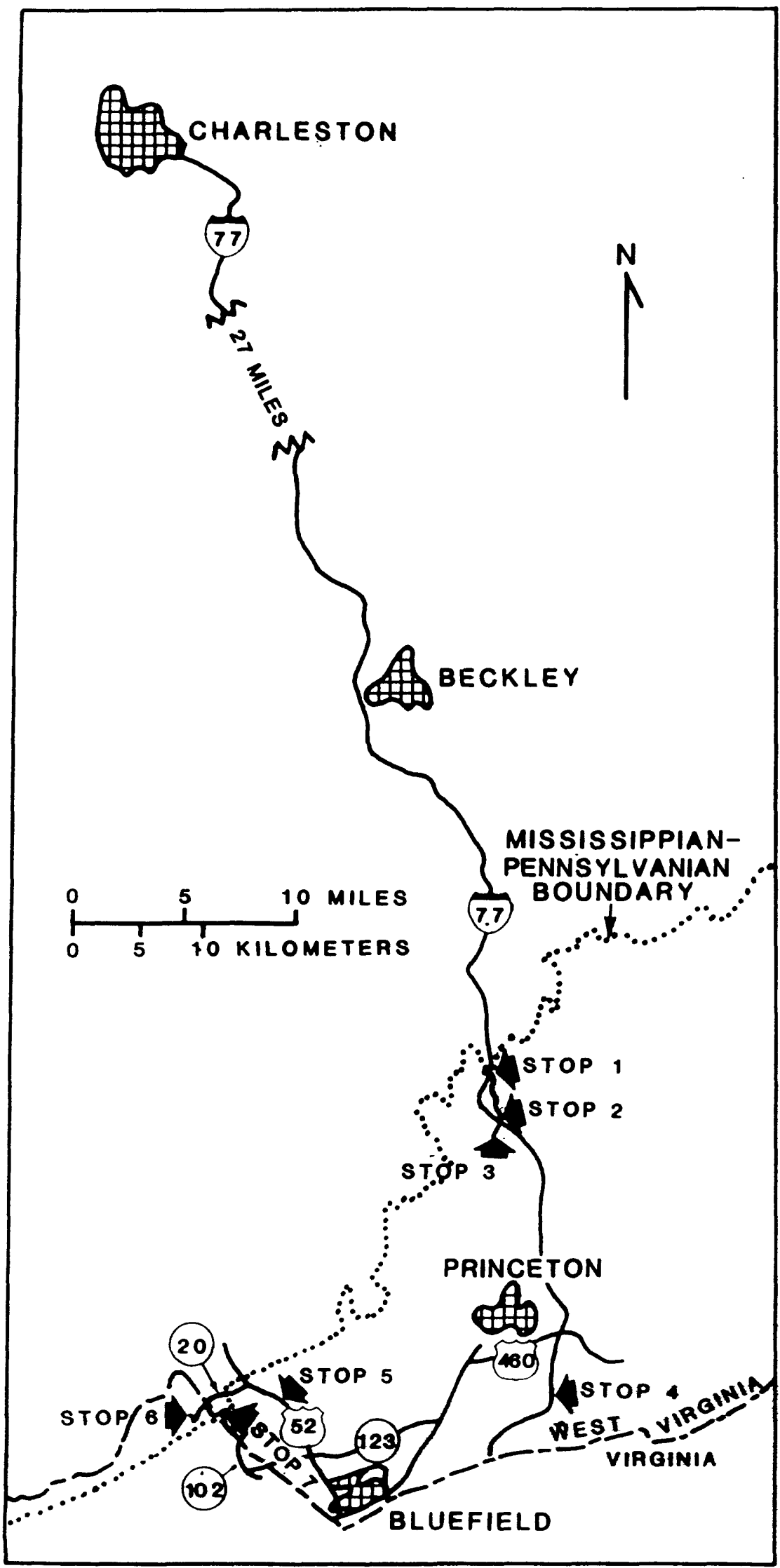

Figure 8. Route map showing first day Stops 1-7. 


\title{
FIELD GUIDE TO UPPER MISSISSIPPIAN AID LONER PBMSYLVANIAN COAL-BEARIIG ROCKS II THE SOUTHERT APPALACHIANS
}

\author{
Kenneth J. Englund ${ }^{1}$, William H. Gillespie ${ }^{2}$, C. Blaine Cecill, \\ John F. Windolph, Jr. ${ }^{1}$, and Thomas J. Crawford ${ }^{3}$
}

The field excursion begins in central West Virginia and proceeds southeastward to the Bluefield-Princeton area for an overview of Middle and Lower Pennsylvanian and Upper Mississippian Formations associated with the Mississippian-Pennsylvanian boundary in the central part of the Appalachian basin ( $f i g$. 8). From the Bluefield-Princeton area of southeastern West Virginia and southwestern Virginia, the trip continues southwestward and parallels the southeastern edge of the coal basin across parts of southwestern Virginia, eastern Kentucky, eastern Tennessee, and northwestern Georgia. Intermediate stops will be focused on variations in the boundary relation and associated strata with emphasis on depositional environments and regional facies trends. Areas covered by this traverse also feature differences in the stratigraphic nomenclature applied to Opper Mississippian and Lower Pennsylvanian rocks. To indicate regional stratigraphic relations and the extent of units, an attempt is made to supplement the local stratigraphic names by applying the nomenclature as used in southeastern West Virginia and southwestern Virginia.

ROAD LOG AND STOP DESCRIPTIONS

CHARLESTON TO BLUEFIELD, WEST VIRGINIA

Mileage

Cumulative

$0.0 \quad 0.0$

$0.2 \quad 0.2$

$0.6 \quad 0.4$

$1.9 \quad 1.3$

$2.5 \quad 0.6$
Depart downtown Charleston, WV, proceed westward on Kanawha Boulevard.

Turn right onto US 119.

Cross Washington Avenue at traffic light, continue northward on US 119 moving into left lane for access to I-77 southward.

Exposures to left are in Middle Pennsylvanian Charleston Sandstone. Upper No. 5 Block coal bed is near top of cuts.

State Capital to right, highway is just below top of Kanawha Formation.

\footnotetext{
T.S. Geological Survey, Reston, Virginia 22092

20.S. Geological Survey, 916 Churchill Circle, Charleston, West Virginia 25314

${ }^{3}$ Geology Department, West Georgia College, Carrollton, Georgia 30118
} 


\begin{tabular}{|c|c|c|}
\hline 5.5 & 3.0 & Cuts to left are in upper part of Kanawha Formation. \\
\hline 5.9 & 0.4 & $\begin{array}{l}\text { West Virginia Turnpike, continue southbound on } \mathrm{I}-77 \\
\text { toward Beckley, WV. }\end{array}$ \\
\hline 12.6 & 6.7 & $\begin{array}{l}\text { Crest of gently northeastward plunging Warfield } \\
\text { anticline. Eagle coal bed is just above water level } \\
\text { on opposite side of Kanawha River. It is about } 430 \\
\text { ft above base Kanawh Format ion and is } \\
\text { stratigraphically the lowest extensively mined coal } \\
\text { bed in upper Kanawha Valley. }\end{array}$ \\
\hline 22.0 & 9.4 & $\begin{array}{l}\text { Strip mines in Winifrede, Coalburg, and Stockt on } \\
\text { coal beds in upper part of Kanawha Formation. }\end{array}$ \\
\hline 44.2 & 22.2 & $\begin{array}{l}\text { Strip mines to left in Eagle, Powellton, and No. } 2 \\
\text { Gas coal beds in lower part of Kanawha Formation. }\end{array}$ \\
\hline 47.3 & 3.1 & $\begin{array}{l}\text { Broad bench held up by quartzose Nuttall Sandstone } \\
\text { Member at the top of the New River Formation. }\end{array}$ \\
\hline 56.7 & 9.4 & $\begin{array}{l}\text { Beckley, WV, continue southbound on } \mathrm{I}-77 \text {. Cuts } \\
\text { ahead in New River Formation. }\end{array}$ \\
\hline 61.7 & 5.0 & Abandoned strip mine in Sewell coal bed on left. \\
\hline 62.9 & 1.2 & Little Raleigh coal bed on left. \\
\hline 64.7 & 1.8 & Beckley coal bed on right. \\
\hline 74.7 & 10.0 & $\begin{array}{l}\text { Roadcut to right with Pineville Sandstone Member of } \\
\text { the New River Formation above Pocahontas No. } 6 \text { coal } \\
\text { bed. Onconformity at base of Pineville } \\
\text { progressively truncates Pocahontas Formation and } \\
\text { upper part of Mississippian System to northwest. } \\
\text { Cuts ahead in Pocahontas Formation. }\end{array}$ \\
\hline 77.7 & 3.0 & Base of Pocahontas Formation. \\
\hline 80.7 & 3.0 & $\begin{array}{l}\text { Bear right at Camp Creek Exit, follow access to left } \\
\text { on US } 19 \text { northbound. }\end{array}$ \\
\hline 84.0 & 3.3 & Stop 1 \\
\hline
\end{tabular}

\section{WEST VIRGINIA TURNPIKE SECTION}

Approximately $400 \mathrm{ft}$ of section are exposed in roadcuts along $\mathrm{I}-77$ at Stop 1. This section ( $f$ ig. 9) includes the upper part of the red member of the Bluestone Formation, the Bramwell Member of the Bluestone Formation, and the lower part of the Pocahontas Formation up through the Pocahontas No. 3 coal bed. This stop provides an excellent opportunity to study the significant paleobotanical, geochemical, and sedimentological changes across the Mississippian-Pennsylvanian boundary in an area of continuous sedimentation. 


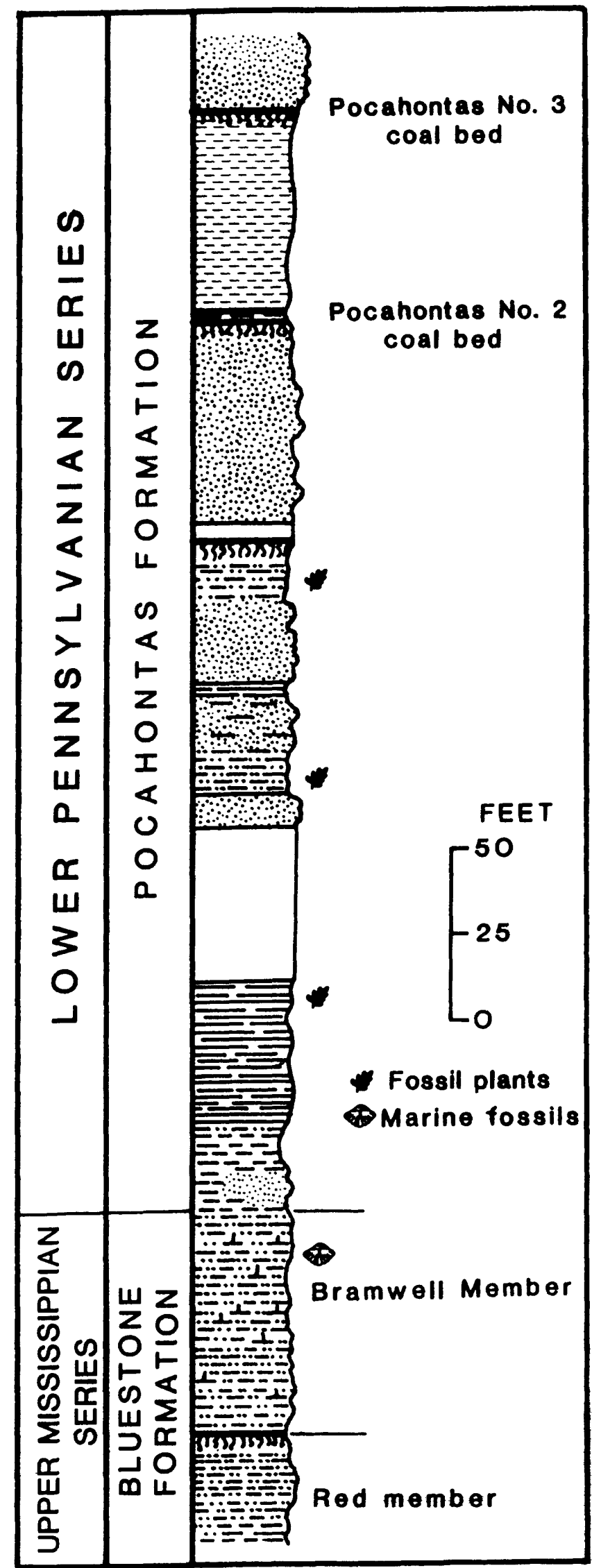

Figure 9. Columnar section of strata exposed along West Virginia Turnpike $(1-77)$ at stop 1. 
Many of these changes appear to be the result of a major change in paleoclimate. The red member of the Bluestone Formation consists of grayishred and greenish-gray sandstone, siltstone, and shale. These strata were deposited in a coastal plain enviroment which persisted from the deposition of the Pride Shale and Glady Fork Sandstone Members up to the marine Bramwell Member. The rocks are highly calcareous and calcareous nodules in rooted paleosols are common. Lenticular sandstone units as much as $15 \mathrm{ft}$ thick are suggestive of small fluvial systems which flowed across the area. Coal beds are thin, discontinuous, and impure although rooted underclays are rather common. A dry to seasonally dry paleoclimate is indicated by the presence of calcareous paleosols (caliche), the limited occurrence and poor quality of coal beds, and paleobotanical evidence presented by White (1913).

The Bramwell Member, which is $60 \mathrm{ft}$ thick at Stop 1, represents a marine transgression over the coastal-plain deposits of the red member. About $2.5 \mathrm{ft}$ of carbonaceous shale at the base of the Bramwell overlies a rooted underclay. This shale contains fresh-water ostracodes at the base and a brackish-water fauna in the upper part indicating transgressive conditions (Englund and Henry, 1981). The remainder of the Bramwel 1 Member is greenish-gray, calcareous siltstone and shale, which is typical of the member. Smal1-scale ripple and flaser bedding are the dominant bed forms. The unit is moderately bioturbated. Marine fossils are scarcer and of lower diversity than at other localities. This paucity of marine fossils, bioturbation, ripple and flaser bedding are all consistent with deposition in a tidally dominated system.

The Pocahontas Formation is interpreted as a sequence of coastal plain and near-shore marine sediments (Englund and Henry, 1981) that were deposited under a tropical ever-wet climate (Cecil and others, 1985). This wet climate during the Early Pennsylvanian was in marked contrast to the dry or seasonally dry climate of the Late Mississippian. This climate change is indicated by the floral assemblages noted by White (1913), differences in the mineralogy of syngenetic and early diagenetic minerals, and the occurrence and quality of coal beds. In contrast to the Mississippian strata at this locality, calcareous rocks and grayish-red beds are not present in the Pennsylvanian strata.

The sandstone which overlies the Bramwell Member probably represents a small meandering tidal creek deposit in a coastal setting. Tidal marsh and/or tidal flat deposits occur just north of the US 19 overpass. These tidally deposited sandstone and shale beds are in contrast to the deltaic sandstone exposed at Stop 7. These tidal deposits consist of gray siltstone and shale that are bioturbated. Several thin, rooted underclay deposits overlain with thin carbonaceous shale are also present. Marsh sediments contain convolute bedding and locally, Calamites in the growth position.

A quartzose sandstone with an erosional base overlies the tidal marsh complex. This sandstone is approximately $32 \mathrm{ft}$ thick, fine- to medium-grained, and contains large-scale festoon crossbeds in the lower part. Most of the crossbeds dip west-northwest, but a few sets dip east-southeast. The crossbedding is indicative of bidirectional currents in a tidally dominated system in which the ebb tidal currents were dominate over those of the flood tide. The festooning decreases upward, and the sandstone becomes planar- and ripplebedded indicating a decrease in current velocity. The sandstone is overlain by a thin, rooted underclay and coal bed, indicative of sand deposition in a tidal 
system followed by marsh sedimentation and subareal conditions. Approximately $15 \mathrm{ft}$ of gray siltstone and shale of probable tidal marsh origin overlie the thin coal bed. The upper part of the silty shale is rooted and also highly carbonaceous.

Approximately $20 \mathrm{ft}$ of light-gray sandstone overlies the tidal sand and tidal marsh complex. Within this sandstone, sedimentary structures are obscure because of its uniform composition. Sedimentary structures recognizable in fresh samples or fresh outcrop include large-scale features that may be ball and pillow structures, convolute bedding, and large-scale accretionary beds. The accretion bedding may be the result of sedimentation in a river mouth bar, estuarine delta, or perhaps a tidal delta. Although the sedimentary structures cannot be unequivocally interpreted, this sandstone may have been deposited in an estuarine environment which had a strong tidal influence. None of the bed forms are definitive of any particular depositional system; however, they are consistent with deposition in a tidally dominated estuarine environment. Typical fluvial features are not evident. This sandstone may have served as a platform for the initiation of peat formation and the development of the peat forming environment as suggested by Englund and others (1984) for the Pocahontas No. 3 coal bed.

The light-gray sandstone is overlain by approximately $10 \mathrm{ft}$ of rooted underclay and the Pocahontas No. 2 coal bed which is $2.5 \mathrm{ft}$ thick. This coal bed is the lowermost mineable coal bed in the immediate area. It contains about 1 percent total sulfur and yields 10-15 percent ash. Conditions for the formation of high quality peat were not as well developed as for overlying coal beds such as the Pocahontas No. 3 .

The Pocahontas No. 2 coal bed is separated from the Pocahontas No. 3 by approximately $50 \mathrm{ft}$ of silty shale. The Pocahontas No. 3 is a low-volatile bituminous coal which generally contains less than 1 percent total sulfur and yields less than 6 percent ash. At Stop 1, the Pocahontas No. 3 consists of thin beds of coal intercalated with carbonaceous shale. This locality is at the edge of the Pocahontas No. 3 paleoswamp, but coal of mineable thickness and quality occurs less than one mile to the southwest. The paleoswamp to the southwest developed under a tropical everwet climate, it was ombrogenous, domed, and highly acidic. These physical and geochemical conditions of peat formation were conducive to the formation of the low-ash and low-sulfur coal bed (Cecil and others, 1985). The thickest part of the coal bed developed over platforms of sand in delta lobes (Englund, 1974).

Mileage - Continued

Cumulative Increment

Retrace route on US 19 southbound to Camp Creek Exit

87.3

3.3

Stop 2 .

\section{CAMP CREER INTERCHANGE SECTION}

A widespread and lithically distinct bed in the Upper Mississippian - the Pride Shale Member of the Bluestone Formation - is exposed at Stop 2 ( $\mathrm{fig}$. 10). The underlying Princeton Sandstone and the overlying Glady Fork Sandstone Member of the Bluestone, both consisting mostly of fine- to coarse-grained, calcite-cemented, conglomeratic sandstone, are also present in this sequence. 


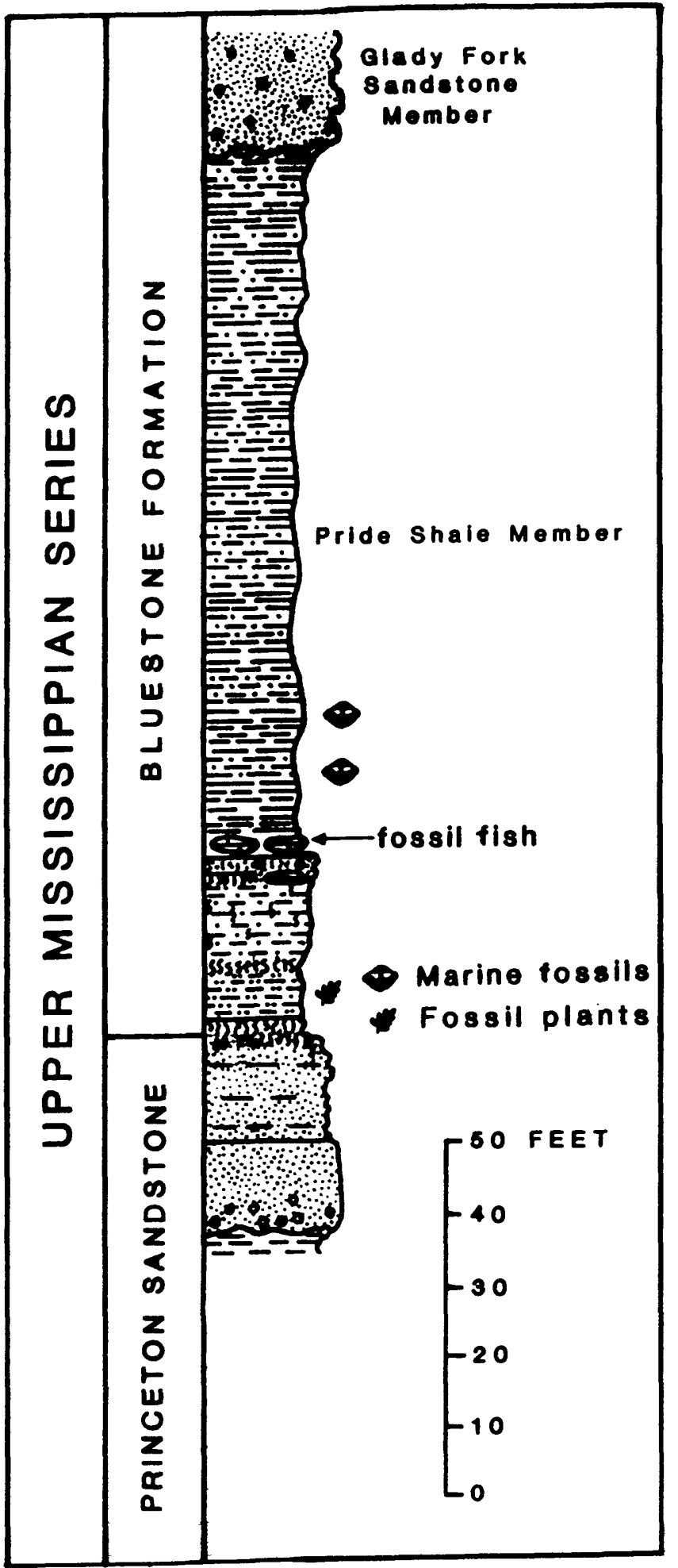

Figure 10. Upper Mississippian strata exposed at the Camp Creok interchange of $1-77$ at stop 2 . 
The Pride Shale Member is nearly $100 \mathrm{ft}$ thick and consists largely of dark-gray shale with nodules and concretions of pyrite, siderite, and 1 imestone. Basal beds of the member include about $25 \mathrm{ft}$ of medium- to dark-gray, sparsely rooted, shale and silty shale. Fresh-water marsh deposition is indicated by the presence of the rooted beds and by brightly banded coal as much as 2 in. thick. This basal unit of the Pride Shale Member appears to grade laterally into uppermost beds of the Princeton Sandstone. The roof shale of the thin coal beds contain partially abraded plant fossils such as Sphenophyllum tenerrimum, stigmaria stellata, Pecopteris aspera, Archaeocalamites sp. and Sphenopteris elegans. This flora is characteristic of the Upper Mississippian of North America and the Namurian $A$ of western and central Europe. It succeeds the Fryopsis zone (zone 3 of Read and Mamay, 1964) and precedes the Neuropteris pocahontas zone (zone 4 of Read and Mamay, 1964) at the base of the Pennsylvanian System. Coal laminae, limestone nodules, and a few inches of conglomeratic sandstone commonly occur near the contact with the overlying dark-gray shale and silty shale of the Pride Shale Member. The lower part of the dark-gray shale contains brackish-water invertebrates and fresh-water to brackish vertebrates including a new genus and species of fossil $\mathrm{fish}$, Tanypteryx pridensis (Weems and Windolph, in preparation), collected recently at this locality from a large limestone concretion. This specimen has thick bony scales, is deep bodied, and has an unusually long pectoral fin. Its closest 1 iving relative is represented by the fresh-water sturgeon. The proximity of overlying marine beds suggests that the demise of this fish was due to the encroachment of saline water.

In addition to flaser and lenticular bedding with bidirectional crossbedding, the Pride Shale Member contains large-scale discordant bedding features that have been interpreted as slump structures (Cooper, 1961). Eroded surfaces associated with these features may have resulted from submarine scour and channeling by abnormally strong bottom currents. Bedding within the discordant blocks appears to be consistent with channel fill. However, some slumping may have occurred along channel margins. Subaqueous channels, rhythmic bedding, subtle bidirectional crossbedding, and burrows indicate that the Pride was deposited in a shallow marine or estuarine environment.

Mileage - Continued

Cumulative Increment

Continue on US 19 southward.

$88.0 \quad 0.7 \quad$ Stop 3 .

CAMP CREEK SECTION

The Princeton Sandstone at Stop 3 is a 100-ft-thick sequence of sandstone and conglomeratic sandstone with interbeds of shale and silty shale (fig. 11). It has been described as a polymictic conglomerate or a coarse conglomerate subgraywacke (Cooper, 1961, p. 69) and consists mainly of 1ight-gray, fine- to coarse-grained, thick-bedded to massive, calcite-cemented sandstone. Clasts in the formation are highly diverse in composition, size, and abundance and are composed of wel1-rounded to angular fragments of quartz, shale, siltstone, limestone, chert, and ironstone. Cooper (1961) suggested that these clasts were derived from formations ranging in age from Silurian to Mississippian 


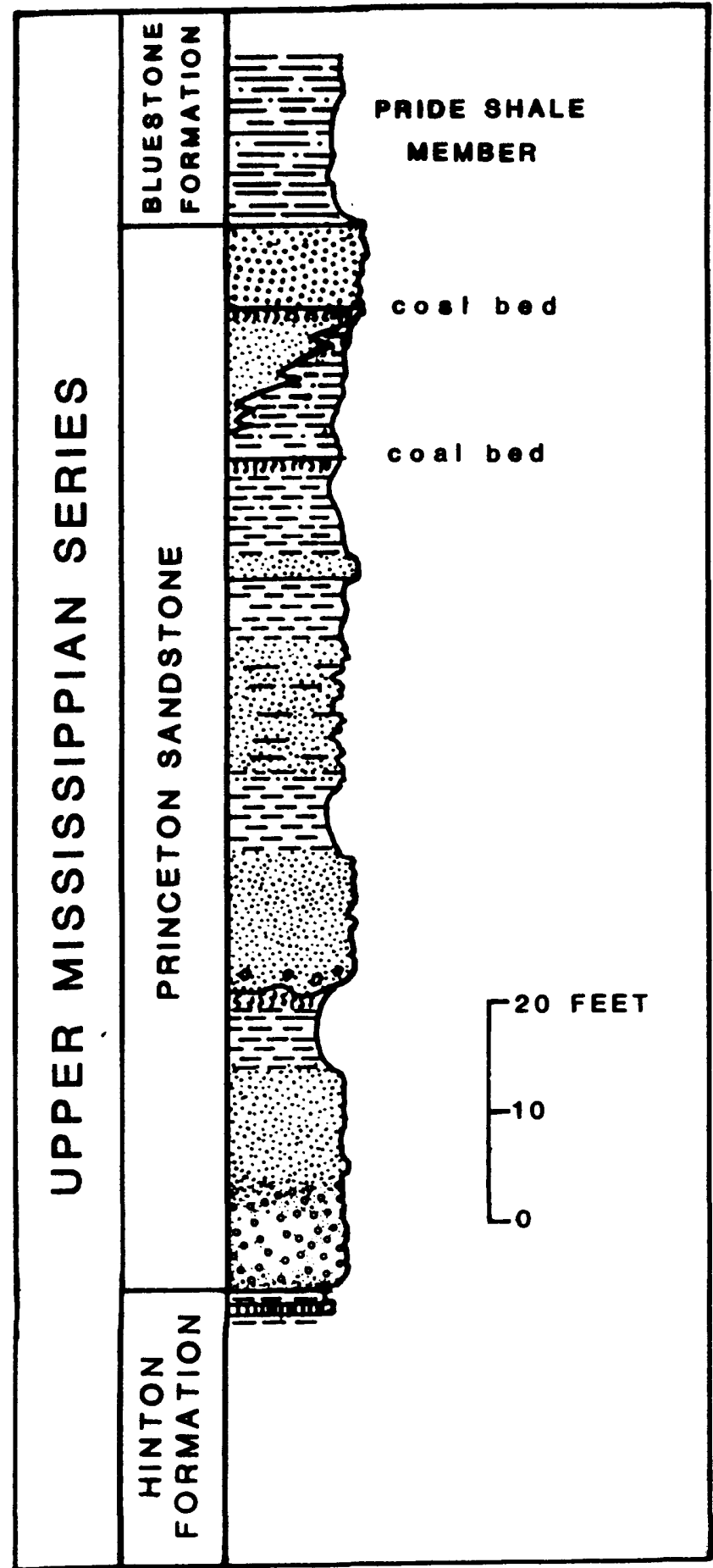

Figure 11. Princeton Sandstone exposed at Stop 3 on Camp Creok. 
which is feasible in view of the regional disconformity at the base of the Princeton. Southwestward along the outcrop in Virginia and westward in West Virginia, the Princeton becomes less conglomeratic, thinner, and finer grained before tonguing out at the base of the Pride Shale Member of the overlying Bluestone Formation (Englund and Randa11, 1981). The disconformity then coincides with the base of the Pride Shale Member which core drilling showed is in contact with the Little Stop Gap Member of the Hinton Formation locally in central West Virginia as a result of truncation or erosion.

The depositional environment of the Princeton appears to be diverse: the presence of calcareous cement and scattered marine fossils (Gordon and Henry, 1981) suggests near-shore marine conditions; angular clasts of locally derived limestone and shale support a catastrophic origin such as a storm breccia; well-rounded pebbles from a distant source indicate stream transport; and coal beds associated with rooted sediments represent fresh-water marsh deposits. The Princeton probably reflects environments ranging from nearshore marine to terrestrial that were associated with a regressive phase between major marine incursions in underlying and overlying beds.

Mileage - Continued

Cumulative Increment

Retrace route on US 19 northbound to Camp Creek Exit.

88.2 0.2 Camp Creek Exit, turn right on access road to I-77 southbound.

100.1 11.9 Junction US 460, continue southbound on I-77.

100.5 0.4 Pride Shale Member and overlying Glady Fork Sandstone Member of Bluestone Formation on both sides of highway.

$102.5 \quad 2.0 \quad$ Red member of Bluestone Formation in roadcut on right.

104.1 $\quad 1.6 \quad$ Bluefield Formation exposed on both sides of highway.

$105.9 \quad 1.8 \quad$ Big Stone Gap Member of Chattanooga Shale at base of Mississippian System underlain by Chemung Formation (Devonian).

106.2 0.3 Braillier Shale (Devonian) in roadcut on right.

$107.7 \quad 1.5$ Trace of St. Clair fault. Leave I-77 at Exit 1.

$107.9 \quad 0.2 \quad$ Ordovician carbonates on both sides of road for next $0.3 \mathrm{mi}$.

108.0 $0.1 \quad$ Turn left on State Route 290. 


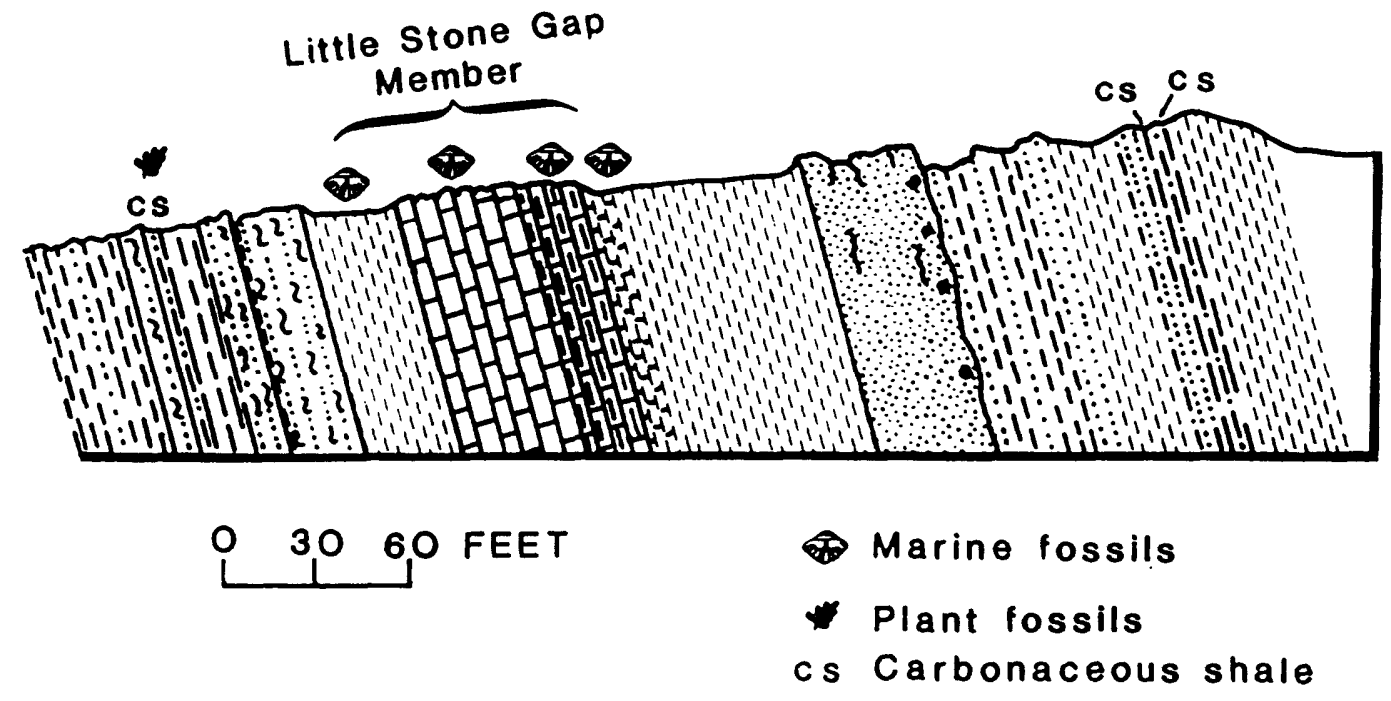

Figure 12. Profile of overturned, steeply dipping beds in upper part of Hinton Formation at Stop 4 near Ingleside. West Virginia. 


$\begin{array}{lll}108.2 & 0.2 & \text { Turn left on } \mathrm{I}-77 \text { northbound. } \\ 110.8 & 2.6 & \text { Greenbrier Limest one on right. } \\ 112.9 & 2.1 & \text { Stop } 4 .\end{array}$

\section{INGLESIDE SECTION}

A thick, widely recognized sequence of argillaceous 1 imestone and calcareous shate in the upper part of the Hinton Formation (fig. 12) is assigned to the Little Stone Gap Member or Avis Limestone of Reger (1926). It attains its maximum thickness of about $100 \mathrm{ft}$ at $\mathrm{Stop} 4$ and is distributed primarily along strike in the geosynclinal trough from east-central Tennessee to northern West Virginia. Westward across the Appalachian basin the member thins and is truncated in eastern Tennessee and Kentucky at the MississippianPennsylvanian unconformity. A diverse marine fauna was identified at 5 top 4 by Gordon and Henry (1981), including the brachiopods Orthotetes aff., $\underline{0}$. kaskaskiensis (McChesney) n. sp. A. Orthotetes subglobosus Girty n. subsp., Diaphragmus cestriensis (Worthen), Productus n. sp. A., Ovatia aff. 0 . pileiformis (McChesney), Composita subquadrata (Ha11), Martinia contracta (Meek and Worthen), and Eumetria? sp. indet., numerous pelecypods, scattered gastropods, abundant bryozoans, pelmatozoan fragments, and representatives of other organic groups. They reported that this fauna and others from the Little Stone Gap Member support a correlation with the Menard Limestone in the middle to upper part of the type Chesterian Provincial Series.

The strata underlying and overlying the Little Stone Gap Member are dominated by grayish-red shale and siltstone and represent a transition to less marine and to nonmarine conditions ranging from tidal flat to coastal plain. Thin beds of coal, carbonaceous shale, rooted underclay, and other plantbearing beds indicate the seaward or northwestern edge of coastal peat swamps. These terrestrial beds wedge out immediately to the northwest and increase in thickness to the southeast, a relationship that concurs with the concept that coal deposition began in Late Mississippian time and continued into the Early Pennsylvanian in association with the northwestward encroachment of terrestrial facies across the Appalachian basin.

Mileage - Continued

Cumulative Increment
115.7
2.8
Leave I-77 at Exit 9 .
$116.1 \quad 0.4$
Turn left on US 460 toward Princeton, WV.
$119.9 \quad 3.8$
Pride Shale Member of Bluestone Formation on left.
$122.6 \quad 2.7$
Turn right on State Route 123. Route extends south- westward in trough of Hurricane Ridge syncline for next $11 \mathrm{mi}$.
$127.3 \quad 4.7$
Bramwell Member of Bluestone Formation in roadcuts to left. 
46

SOUTHWEST

NORTHEAST

Cumberland Gap Area

Bluefield Area

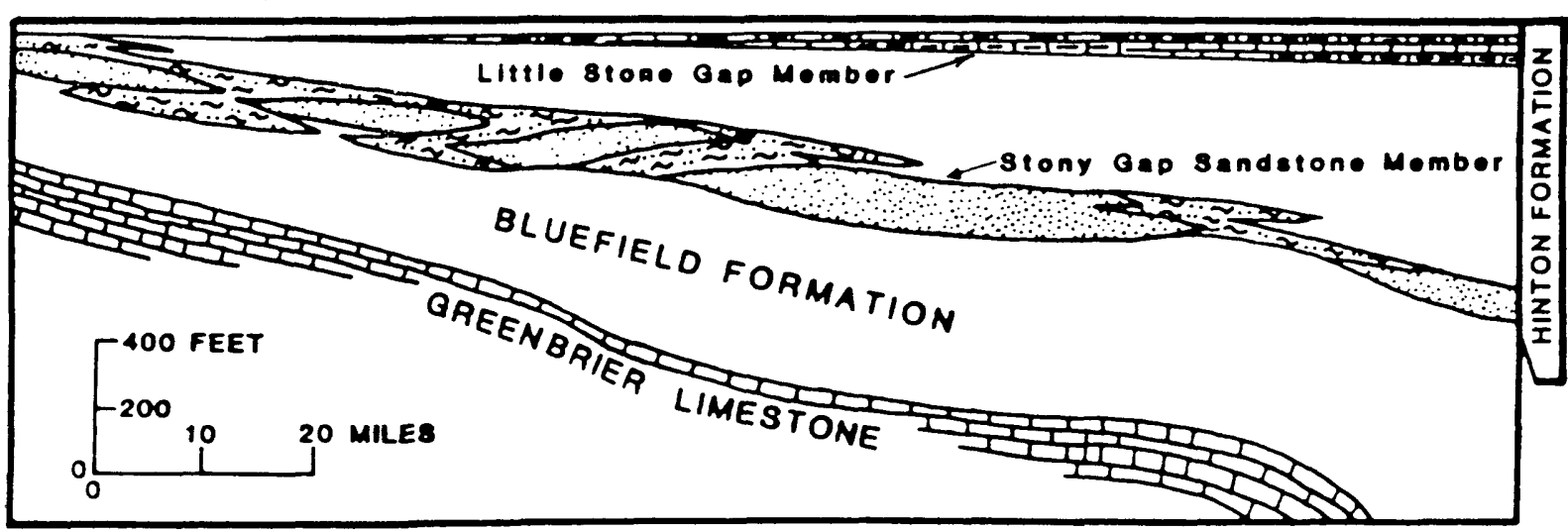

Figure 13. Generallzed reglonal crose section of Stony Gap Sandetone Member of Hinton Formation. 


\begin{tabular}{|c|c|c|}
\hline 127.5 & 0.2 & $\begin{array}{l}\text { Lower sandstone member of Pocahontas Formation in } \\
\text { roadcuts at gap. }\end{array}$ \\
\hline 130.2 & 2.7 & Turn right on US 52 northbound. \\
\hline 131.7 & 1.5 & Little Stone Gap Member of Hinton Formation on right. \\
\hline 134.2 & 2.5 & $\begin{array}{l}\text { Stony Gap Sandstone Member of Hinton Formation in } \\
\text { roadcuts at gap. }\end{array}$ \\
\hline 134.4 & 0.2 & Stop 5 . \\
\hline
\end{tabular}

\section{PINNACLE ROCK STATE PARK}

Steeply dipping beds at this locality are on the northwestern limb of the Abbs Valley anticline. Pinnacle Rock, a precipitous ledge at the ridge crest, is formed by the Stony Gap Sandstone Member at the base of the Hinton Formation. It is a wel1-sorted, highly quartzose sandstone and, because of its resistant character, is the principal ridge- and cliff-forming unit in this area at the eoutheastern edge of the coal field. The proximity of local marine beds in the Bluefield and Hinton Formations immediately below and above the Stony Gap Sandstone Member, together with its 1 ithic character and local geometry, indicate that it was deposited as an offshore bar in a tidally dominated system. As mapped regionally, the Stony Gap Sandstone Member represents a coalescing of of fshore bars (fig. 13).

Mileage - Continued

Cumulative Increment

$\begin{array}{lll}135.5 & 0.1 & \text { Bramwell Member of Bluestone Formation on right. } \\ 135.8 & 0.3 & \text { Turn left on State Route } 20 . \\ 138.9 & 3.1 & \text { Pocahontas No. } 3 \text { coal bed in cut on right. } \\ 139.2 & 0.3 & \text { Turn right on State Route } 644 . \\ 140.0 & 0.8 & \text { Pocahontas, VA. Turn right on State Route } 644 . \\ 140.5 & 0.5 & \text { Stop } 6 .\end{array}$

\section{POCAHONTAS EXHIBITION MINE}

The Pocahontas Formation is $700 \mathrm{ft}$ thick here in the type area and includes ten coal beds in a sequence of sandstone, siltstone, shale, and underclay. Most of these rocks were deposited in deltaic lobes that prograded from the southeast. During periods of relative stability, when subsidence and influx of sediments were minimal, barrier bars formed along the northwestern margins of the lobes and extensive coastal marshes extended across the delta lobes. During these periods, peat accumulated to form thick and extensive coal beds, such as the Pocahontas No. 3 exposed at this locality. 


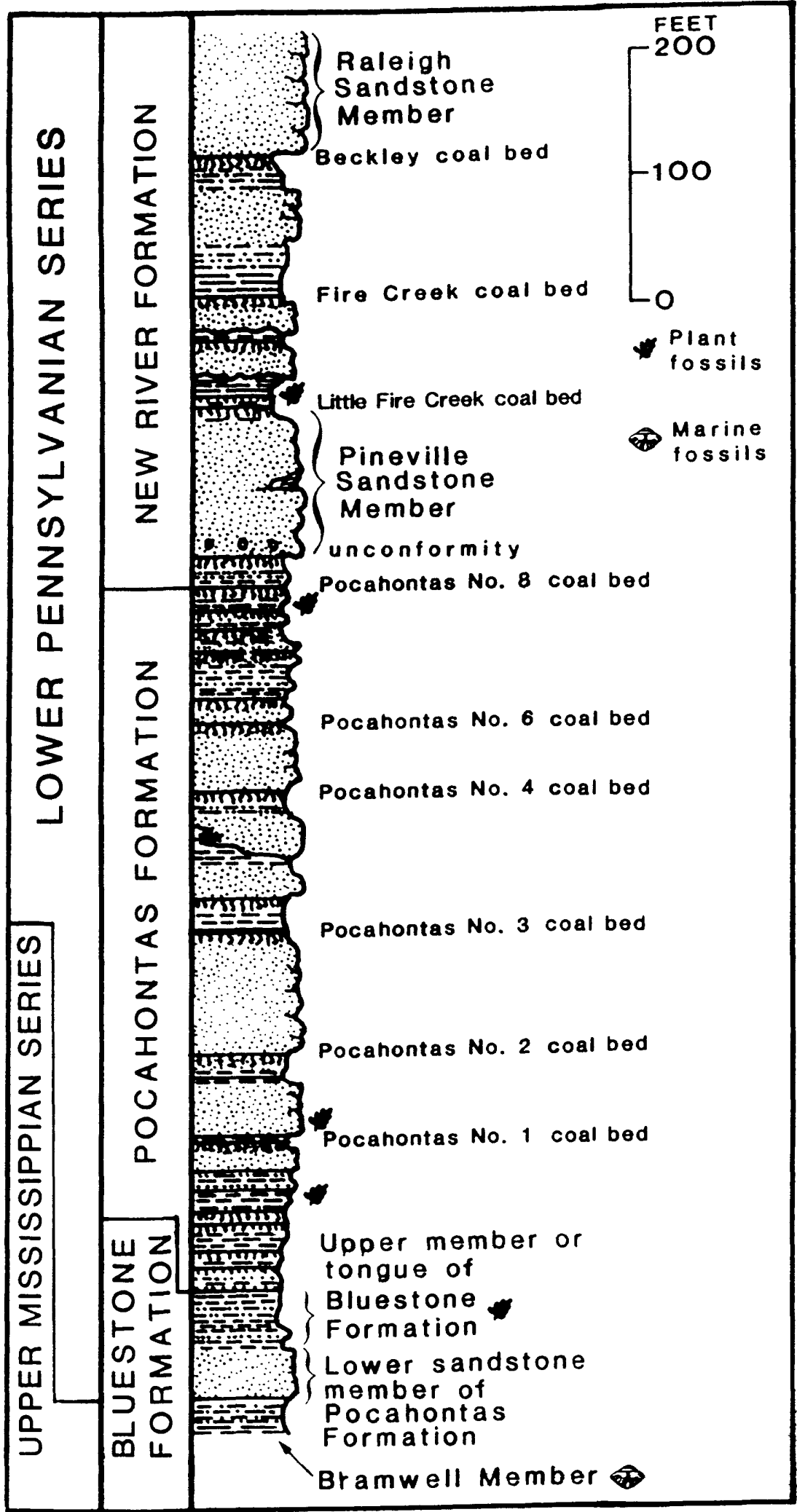

Figure 14. Columnar section of strata exposed along State Route 10 near Garwood. West Virginia (trom Englund and others, 1979). 
The first mining in the Pocahontas coal field was in the Pocahontas No. 3 coal bed in this immediate area, and 44 million tons of coal were produced before this mine was worked out in 1955. The bed is $10 \mathrm{ft}$ or more thick in this area and consists of low-volatile bituminous coal that is also low in ash and sulfur. This coal has excellent coking properties and is in great demand by both the domestic and export markets. The old workings of this mine provide an excellent opportunity to examine the bed in detail, particularly the bright and finely cleated character of the coal. Note also the large lycopod stems and other plant fragments in the shale that forms the roof. Mining has depleted this bed for miles to the north, west, and southwest, but substantial reserves remain farther to the southwest, principally in Buchanan County, Virginia, where the bed is accessible by shafts to depths of $1,400 \mathrm{ft}$ or more. The lack of a continuous, well-exposed section of the Pocahontas Formation here in its immediate type area required the selection of section at Garwood, West Virginia, $12 \mathrm{mi}$ to the north, to represent these rocks in the Pennsylvanian System stratotype (fig. 14).

Mileage - Continued

Cumulative Increment

Retrace route to Pocahontas, VA

$141.0 \quad 0.5 \quad$ Pocahontas, VA. Turn left, continue on West Virginia Route 644 which becomes Virginia Route 102 .

$143.4 \quad 2.4 \quad$ stop 7 .

\section{BLUESTONE SECTION}

The Bluestone section contains the type section of the Bramwel1 Member, the uppermost unit of Mississippian age (fig. 15). This member consists mostly of medium-dark-gray calcareous shale and siltstone that coarsens upward and grades locally into very fine- to fine-grained, ripple-bedded sandstone. The basal bed of the Bramwel1 consists of about $9 \mathrm{ft}$ of black, carbonaceous shale containing abundant ostracodes, pelecypods, and Lingula. Overlying beds of the member, which total $86 \mathrm{ft}$ in thickness, contain articulate brachiopods and pelecypods and a few ellipsoidal limestone concretions as much as $0.5 \mathrm{ft}$ thick by $2 \mathrm{ft}$ in diameter. The Bramwe 11 Member is the youngest marine unit in the area know to contain fossils with unquestioned late Chesterian (Late Mississippian) affinities. Basal beds of the Bramwell record a marine transgression over fresh- or brackish-water sediments. Overlying beds of the Bramwell were deposited during a marine regression, are largely prodeltaic, and grade upward to coarser distal-bar sediments of a prograding delta.

At this locality, the overlying lower sandstone member of the Pocahontas Formation consists of slumped, delta-front siltstone and sandstone succeeded by massive, channel-fill sandstone of a distributary lobe (fig. 2). Pennsylvanian plant fossils, including Neuropteris pocahontas D. White and Mesocalamites sp., have been collected from the delta-front facies but more commonly occur in the beds overlying the lower sandstone member. 


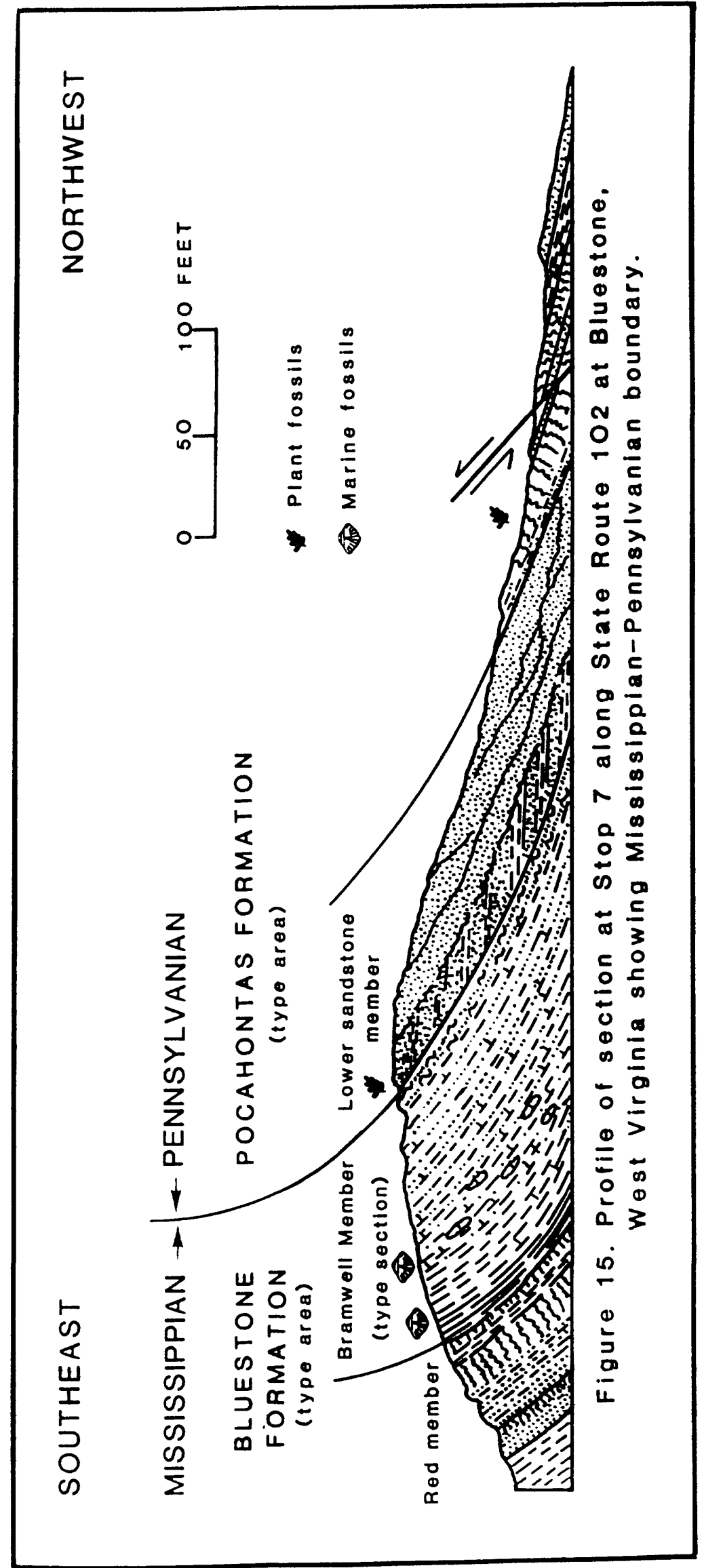


The significance of this section is that it defines the systemic boundary in the type area of both the Bluestone and Pocahontas Formations, which represent the youngest and oldest units, respectively, of the Mississippian and Pennsylvanian Systems in the central Appalachian basin. Furthermore, because of the continuity of deposition here, this section presents the ideal locality in the study area for designating a point-boundary stratotype for the base of the Pennsylvanian System.

Mileage - Continued

Cumulative Increment

\begin{tabular}{|c|c|c|}
\hline 144.5 & 1.1 & $\begin{array}{l}\text { On left, Greenbrier Limestone exposed in abandoned } \\
\text { quarry at crest of Abbs Valley anticline. }\end{array}$ \\
\hline 147.3 & 2.8 & Turn left on State Route 123. \\
\hline 151.5 & 4.2 & $\begin{array}{l}\text { Turn right on US } 52 \text {. Pride Shale Member of Bluestone } \\
\text { Formation in cuts at intersection. }\end{array}$ \\
\hline 153.4 & 1.9 & Bluefield, wV. Bear right and continue on US $19-52$. \\
\hline 156.3 & 2.9 & Turn right on US 19 . \\
\hline 157.8 & 1.5 & Turn right on US $52 \mathrm{~s}$. \\
\hline 158.3 & 0.5 & Bluefield, WV. \\
\hline
\end{tabular}

ROAD LOG AND STOP DESCRIPTIONS

BLUEFIELD, WEST VIRGINIA TO CARYVILLE, TENNESSEE

Mileage

Cumulative Increment

$0.8 \quad 0.8$

$\begin{array}{ll}7.8 & 7.0\end{array}$

$20.2 \quad 12.4$

28.2
8.0
Bluefield, WV., proceed eastward on US 52 S. (fig. 16).

Turn right on US 460. Route follows strike of St. Clair thrust fault southwestward for next $5 \mathrm{mi}$.

Intersection US 19-460, bear left and continue west bound.

Turn right on State Route 16 toward Bishop, WV.

Stop 8 


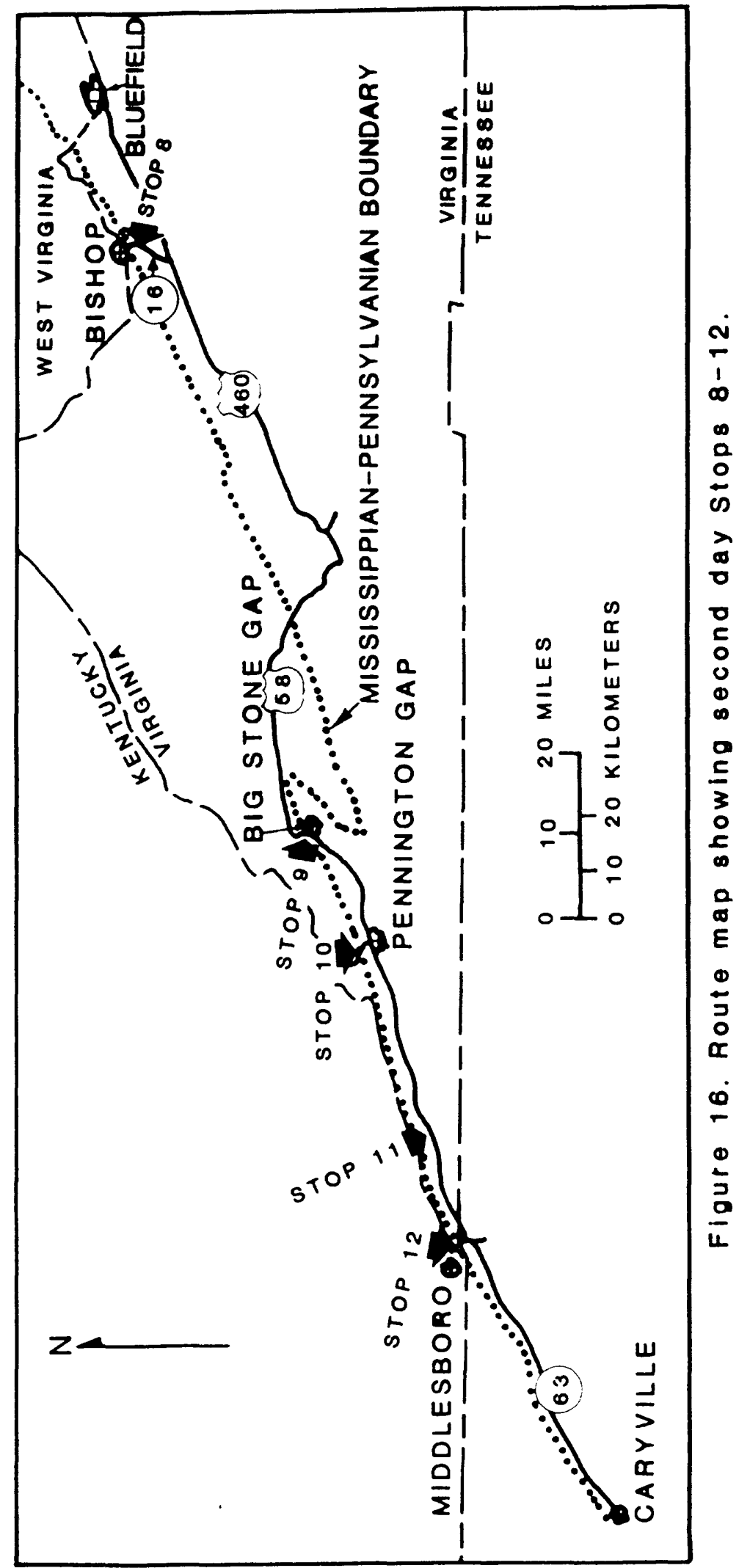




\section{BISHOP SECTION}

The Hinton Formation totals approximately $1,600 \mathrm{ft}$ in thickness at Stop 8, located on State Route 16 on the northwest slope of Stony Ridge (fig. 17). It consists predominantly of grayish-red and greenish-gray shale with interbeds of limestone, sandstone, coal, carbonaceous shale, and rooted underclay. This section is near the southeastern edge of the coal field in a thrust sheet that has moved, probably a few miles, to the northwest. As a result, it is one of the most southeasterly originating sections to be viewed on this excursion and, in conformance with regional trends, it contains the thickest reported Upper Mississippian coal beds. These coal beds are as much as 28 and 30 in. thick but wedge out northwestwardly with the increase in marine influence. Accordingly, this relationship supports the concept that peat (coal) deposition began at the southeastern edge or trough area of the Appalachian coal basin in Late Mississippian time so that Upper Mississippian coal beds tend to be thicker and more numerous to the southeast (Englund and others, in press). Continued regression to the northwest in Early Pennsylvanian time represented a continuation of this trend and eventually resulted in the extension of terrestrial deposits northwestward across the Appalachian basin.

Well preserved plant fossils including Fryopsis (zone 3 of Read and Mamay, 1964) are associated with these coal beds in the lower part of the Hinton. The Little Stone Gap Member in the upper part of the formation is well developed at this locality where it consists of about $80 \mathrm{ft}$ of fossiliferous 1 imestone and shale. The overlying Tallery Sandstone Member is relatively thin and nonresistant at the gap in the ridge crest. However, it is a highly resistant, conglomeratic sandstone at the ridge crest about one mi to the southwest. The Falls Mills Sandstone Member at the top of this section is disconformably overlain by the Pride Shale Member of the Bluestone Formation on the lower southeast slope of Stony Ridge.

Mileage - Continued

Cumulative Increment

Retrace route to US $19-460$.

$\begin{array}{lrl}36.2 & 8.0 & \text { Turn right on US } 19-460 . \\ 46.1 & 9.9 & \text { Intersection, continue ahead on US } 19 . \\ 75.7 & 29.6 & \text { Turn right on A1ternate US } 58 . \\ 112.1 & 36.4 & \text { Norton, VA. Turn left, continue on Alternate US } 58 . \\ 125.1 & 13.0 & \text { Stop } 9 .\end{array}$

BIG STONE GAP SECTION

Steeply dipping beds of Late Mississippian and Early Pennsylvanian age at Big Stone Gap are on the northwest 1 imb of the Powell Valley anticline. The Upper Mississippian sequence in this area is lithically similar to its counterpart in southern West Virginia. It is best exposed in railroad cuts on the less accessible northwest side of the gap. These outcrop consist largely 


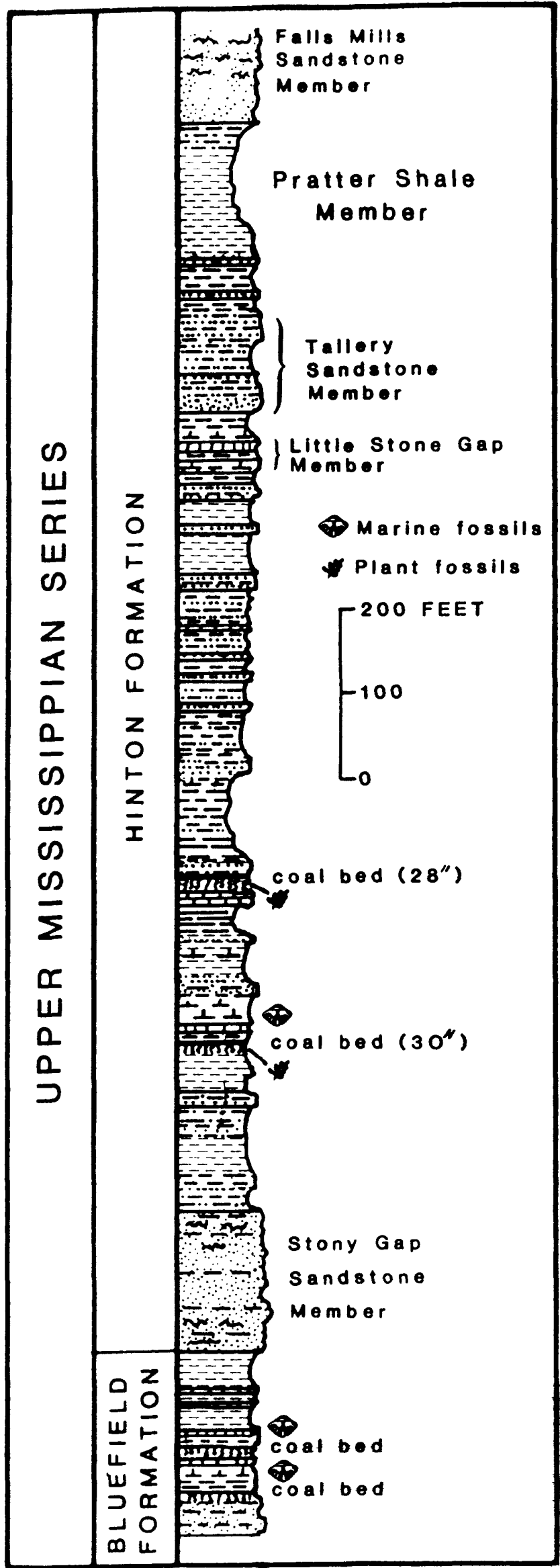

Figure 17. Upper Mississippian strata exposed on State Route 16 near Bishop. West Virginia at stop 8. 


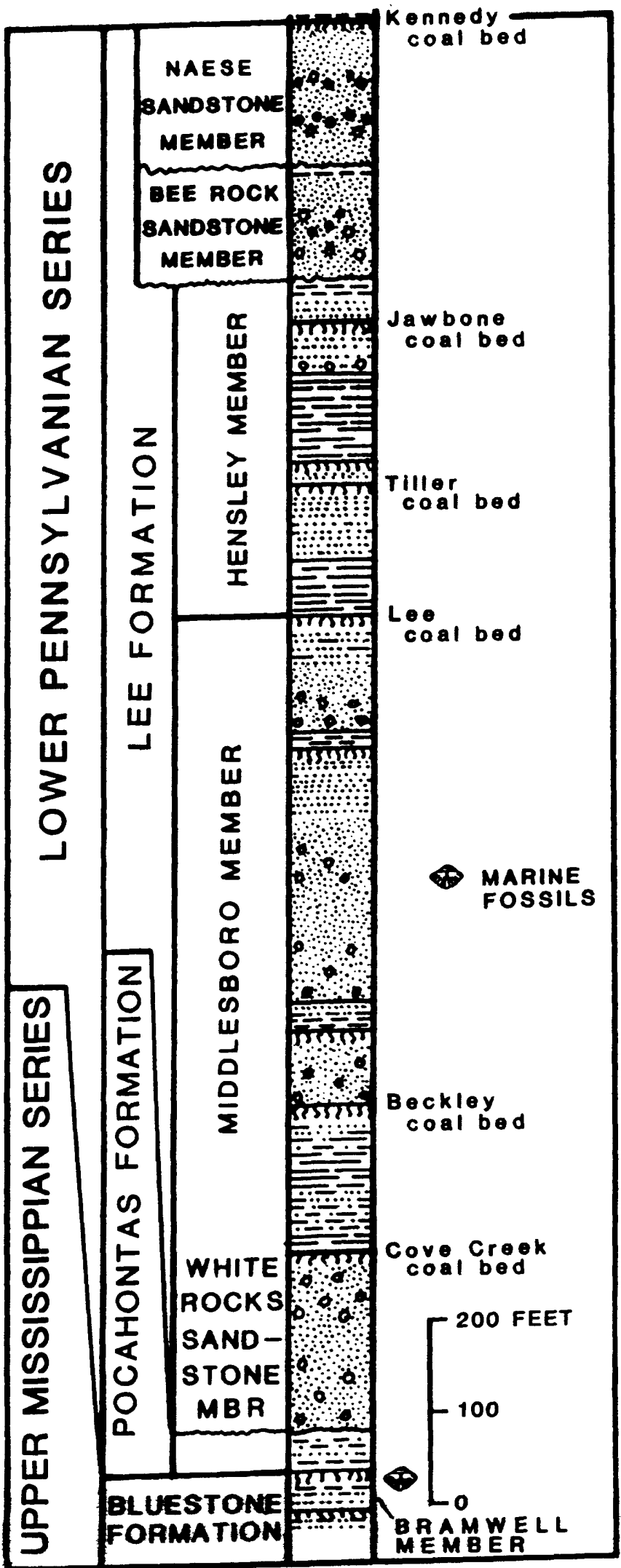

Figure 18. Section of the Lower Pennsylvanian rocks in Big Stone Gap area. Assembled from core holes $\theta$ and $\theta A$ located $4.5 \mathrm{mi}$ southwest of Big Stone Gap (Englund and others, 1983). 
of the Greenbrier Limestone, which has been extensively quarried, the Bluefield Formation, and the Hinton Formation including the basal stony Gap Sandstone Member, the fossiliferous Little Stone Gap Member, and the conglomeratic and quartzose Tallery Sandstone Member. The Bramwell Member of the Bluestone contains abundant marine invertebrates, where it has been penetrated by several core holes in the immediate area (fig. 18). Only the lowermost part of the overlying Pocahontas Formation is present in the Big Stone Gap area. It is as much as $40 \mathrm{ft}$ thick but is truncated abruptly to the northwest by the unconformity at the base of the Lee Formation. In core holes along Pine Mountain (Englund and others, 1983), about $15 \mathrm{mi}$ to the north, the Pocahontas is absent and the base of the Lee Formation unconformably overlies the stratigraphically lower Pride Shale Member of the Bluestone. Lower Pennsylvanian strata assigned to the Lee Formation also display a significant lithic change along the southeastern edge of the Appalachian basin. Equivalent strata, identified as the New River Formation in southern West Virginia and adjacent parts of Virginia, consist largely of feldspathic sandstone with a relatively low quartz content of 50-65 percent. In a westerly direction, these sandstones grade abruptly into conglomeratic orthoquartzites that cropout in the massive, cliff-forming members evident in the Big stone Gap area. For example, the quartzose Naese Sandstone Member, penetrated in core holes $4.5 \mathrm{mi}$ to the southwest ( $f$ ig. 18) is absent at Big Stone Gap. The underlying Bee Rock Sandstone Member, which defines the top of the Lee Formation at Big Stone Gap, grades to a feldspathic, relatively-low quartz sandstone about $14 \mathrm{mi}$ to the northeast where it also loses its ridge-forming capability. The occurrence of resistant, quartzose sandstone in the Lower Pennsylvanian Series is responsible for the high, cliff-lined ridges that border the southeastern edge of the Appalachian coal field southwestward across Virginia, Tennessee, and Georgia.

Coal in the Lee Formation in the Big Stone Gap area is classified as highvolatile $A$ bituminous and occurs in beds as much as $5 \mathrm{ft}$ thick. Analyses, on an as-received basis, of 33 coal samples obtained from recent core drilling (Simon and Englund, 1983) show that: (1) the ash content ranges from 2.0 to 29.3 percent and averages 10 percent; (2) the sulfur content ranges from 0.5 to 4.2 percent and averages 1.6 percent; and (3) the calorific value averages $12,700 \mathrm{Btu} / 1 \mathrm{~b}$.

Mileage - Continued

Cumulative Increment

126.3 1.2 Big Stone Gap, VA. Turn right and continue westbound on Alternate US 58. Route extends southwestward in Ordovician carbonates on northwest flank of Powell Valley anticline.

144.2 17.9 Pennington Gap, VA. Turn right on US 421.

$145.5 \quad 1.3 \quad$ stop 10 .

PENNINGTON GAP SECTION

Steeply dipping beds of Late Mississippian and Early Pennsylvanian age at Pennington Gap are situated, as at Big Stone Gap, on the northwest limb of the Powell Valley anticline (fig. 19). The sequence is also lithically similar to 


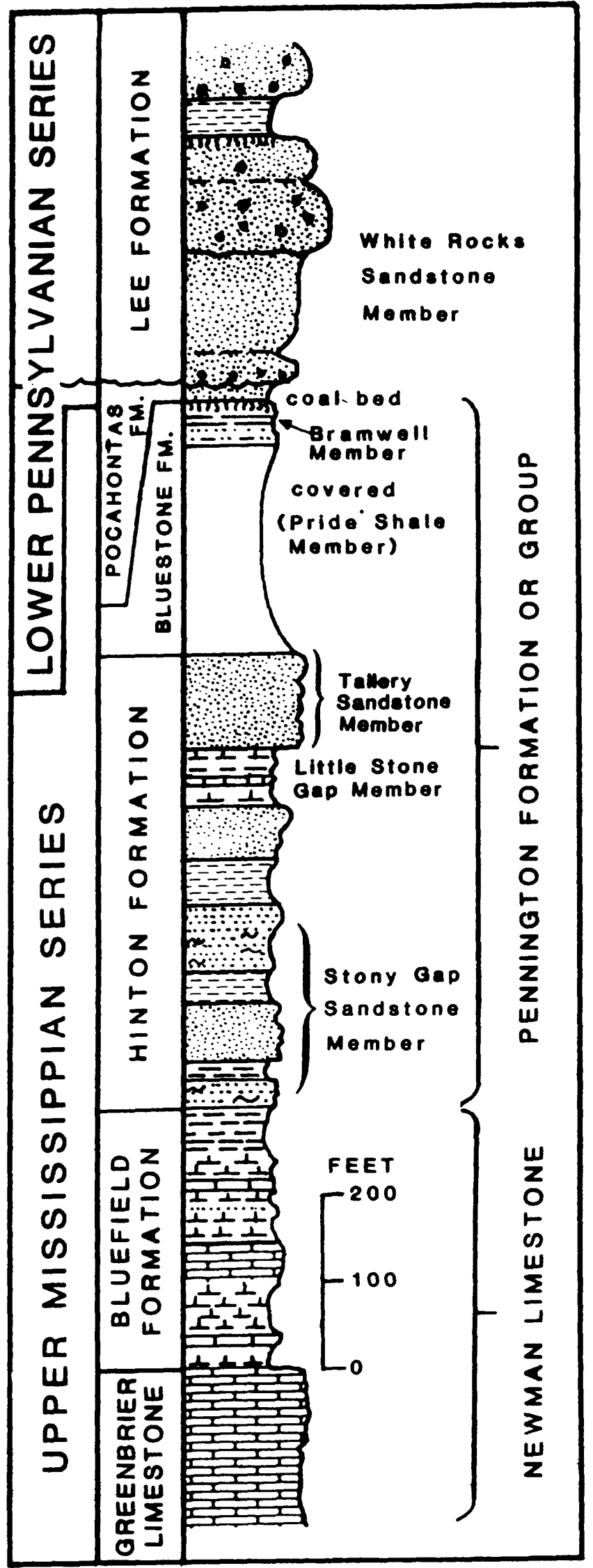

Figure 18. Section of the Upper Mississippian rocks in Pennington Gap. Virginia at Stop 10. 
that at Big Stone Gap but is of regional stratigraphic interest as it is in the type locality of the Pennington Formation or Group (Campbel1, 1893) -- terms that are applied to rocks equivalent to the Hinton and Bluestone Formation southwestward across eastern Kentucky and Tennessee to northeastern Georgia and Alabama. The Penningt on conformably overlies the marine, shale-dominated upper member of the Newman Limestone or Bluefield Formation. Upper Mississippian strata at Stop 10 are situated west of the coal-bearing terrestrial facies noted in correlative beds at previous stops but they do include several widely recognized key beds such as the Stony Gap Sandstone Member, Little Stone Gap Member, and Tallery Sandstone Member of the Hinton Formation, and the Pride Shale and Bramwell- Member of the Bluestone Formation. Another change takes place in the nomeclature of the Tallery Sandstone Member, a conglomeratic orthoquartzite, that is also identified as the Pinnacle Overlook Member or basal tongue of the Lee Formation to the southwest in the Cumberland Gap and Jellico areas. At Stop 10 the Pennington Formation is overlain by the White Rocks Sandstone Member of the Lee Formation, a conglomeratic orthoquartzite, that early studies suggested tongued out between Pennington and Big Stone Gaps (Englund and Delaney, 1960). Subsequent studies by R. L. Miller (1969) indicated that the member does lens out but at a point a few miles northeast of Big Stone Gap. A third interpretation, based on recent drilling (Englund and others, 1983, p. 28) infers that the White Rocks Sandstone Member does not tongue out in the Pennington or Big stone Gap area but it is included undifferentiated within the overlying Middlesboro Member. In this case, it would tongue out considerably further to the northeast where it is known also as the lower quartz arenite (M. S. Miller, 1974) or quartzose, conglomeratic sandstone member of the Lee Formation (Meissner and Miller, 1981).

Mileage - Continued

Cumulative Increment

Retrace route to Penningt on Gap, VA.

$146.8 \quad 1.3 \quad$ Pennington Gap, VA. Turn right on US 58.

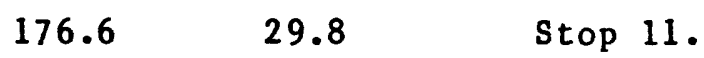

WHITE ROCKS SANDSTONE MEMBER OF THE LEE FORMATION

The Lee Formation is characterized by thick beds of conglomeratic orthoquartzite that may comprise 50 percent or more of the formation. An excellent example is the White Rocks Sandstone Member which attains a maximum thickness of $300 \mathrm{ft}$ in a precipitous cliff at the crest of Cumberland Mountain. Underlying tongues of the Lee Formation are not conspicuous here but toward Cumberland Gap they increase in thickness, become conglomeratic, and also form precipitous cliffs along the crest of the mountain (fig. 20). These tongues Chadwell and Pinnacle Overlook Members - are Late Mississippian in age and intertongue with beds of the Hinton and Bluestone Formations that lie between the Little Stone Gap Member of the Hinton and the White Rocks Sandstone Member.

Regionally, these sandstones are broad lentils that are oriented in a southwest-northeast direction parallel to the axis of the basin. Distribution patterns show a shifting stratigraphically to the northwest in successive lentils. Orthoquartzites of Late Mississippian age are associated with marine 


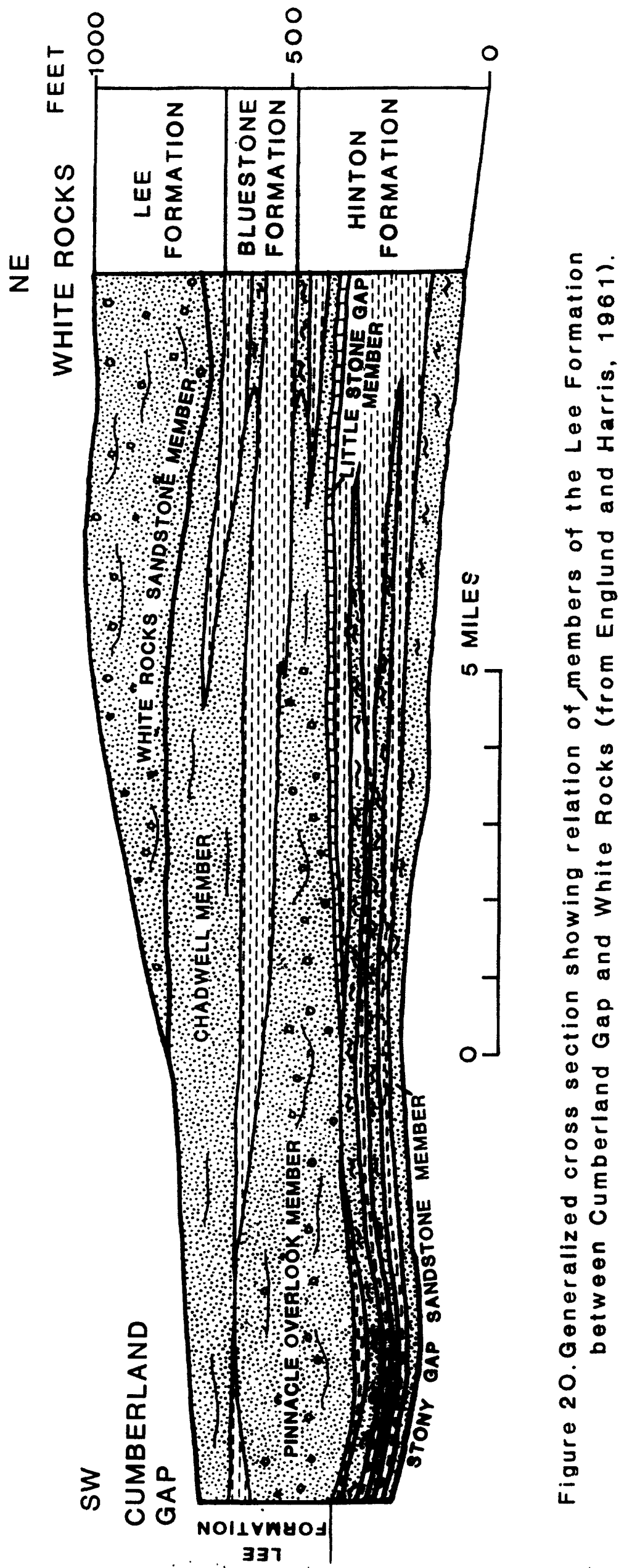


or marginal marine deposits and those of Pennyslvanian age are intercalated with back-barrier and terrestrial coal-bearing beds on the southeast and a few marine beds on the northwest. The origin of these sandstones has been attributed to both marine and terrestrial environments.

Mileage - Continued

Cumulative Increment

$\begin{array}{lll}189.2 & 12.6 & \text { Turn right on US } 25 \text { E northbound. } \\ 191.4 & 2.2 & \text { Turn left on park access road. } \\ 194.8 & 3.4 & \text { Stop } 12 .\end{array}$

CUMBERLAND GAP SECTION

A sequence of Devonian, Mississippian, and Lower Pennsylvanian rocks, totalling about $2,500 \mathrm{ft}$ thick, is exposed at Cumberland Gap. The most significant lithic change from previous stops is in the Upper Mississippian section. At Cumberland Gap, the interval above the Little stone Gap Member of the Hinton Formation is occupied by orthoquartzites of the Lee Formation. The Pinnacle Overlook Member at the base of the Lee attains its maximum thickness of 250 to $350 \mathrm{ft}$ in this area, and, where thickest, the underlying Little Stone Gap Member is commonly truncated.

The Rocky Face fault passes through Cumberland Gap and has a strike-slip displacement of about $11 / 2 \mathrm{mi}$. To the southwest, strata in Powell and Cumberland Mountains are displaced a similar amount by the Doublings fault zone that extends southwestward from the gap ( $f i g .21$ ).

The city of Middlesboro, Kentucky, located northwest of the gap, occupies a broad, circular basin about $4 \mathrm{mi}$ in diameter ( $\mathrm{fig} .22$ ). This feature has been described as a meteor impact scar in which both shocked quartz (Englund and Roen, 1963) and shatter cones (Dietz, 1966) have been found.

Mileage - Continued

Cumulative Increment

Retrace route to US $25 \mathrm{E}$.

$198.2 \quad 3.4 \quad$ Turn right on US 25 E southbound.

$200.9 \quad 2.7 \quad$ Cumberland Gap, TN.

203.1 2.2 Turn right on State Route 63. Route extends southwestward in Cambrian and Ordovician carbonates on northwest flank Powell Valley anticline.

$232.5 \quad 29.4 \quad$ LaFollette, TN. continue ahead on State Route 63 US $25 \mathrm{~W}$.

$240.7 \quad 8.2 \quad$ Caryville, TN.

End of Road Log - Second Day 


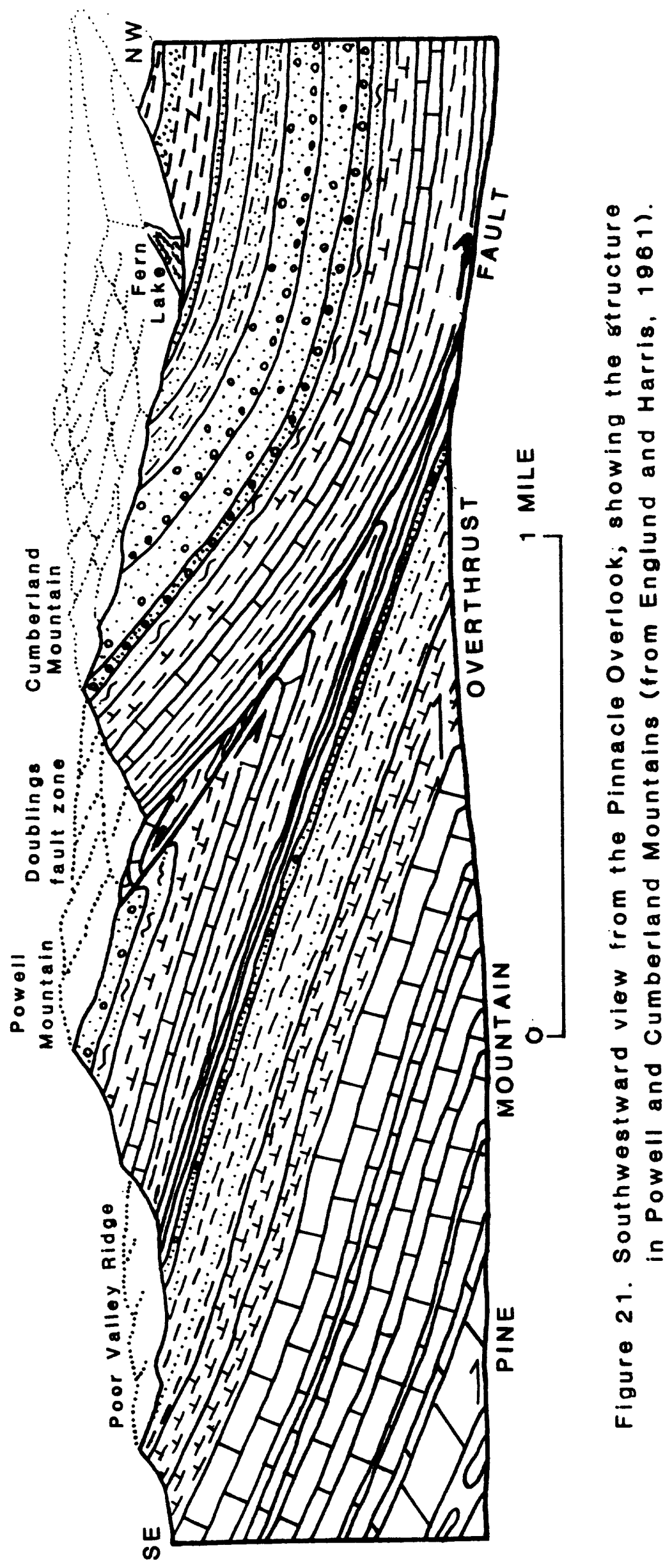




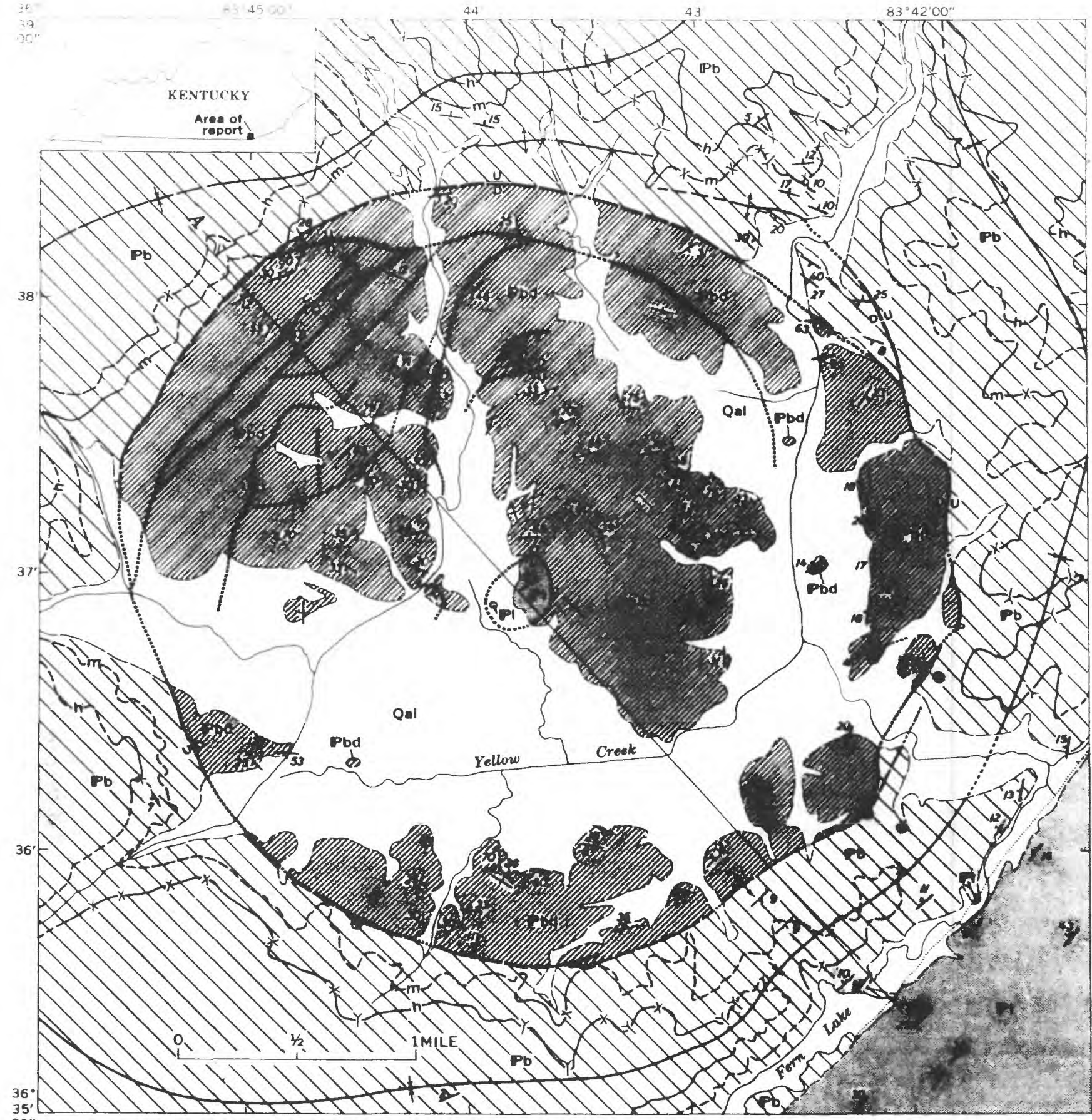

(1)

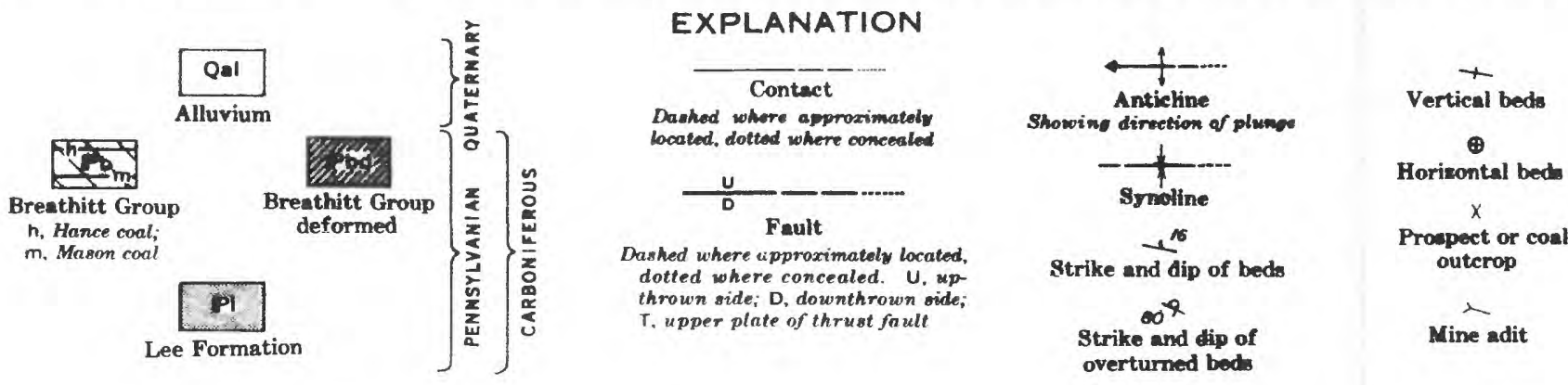

Figure 22. Geologic map of the Middlesboro Basin, Kentucky (from Englund and Roen, 1082). 
ROAD LOG AND STOP DESCRIPTIONS

CARYVILlE TO CHATTANOOGA, TENNESSEE

Mileage

Cumulative Increment

$0.0 \quad 0.0 \quad$ Caryville, TN. Turn left southbound on State Route 63 - US 25 W (fig. 23).

$0.3 \quad 0 . \overline{3}$

Turn right on I-75 northbound. Road follows Jacksboro fault. Knox Group on right and Middle Pennsylvanian rocks on left.

$12.9 \quad 12.6$

Conglomeratic orthoquartzite in Middlesboro Member of Lee Formation on both sides of highway.

$22.9 \quad 10.6 \quad$ Stop 13 .

\section{JELLICO SECTION}

The sequence of Devonian, Mississippian, and Lower Pennsylvanian rocks exposed at Stop 13 overlies the Pine Mountain thrust fault at the northwest edge of the Cumberland overthrust sheet (fig. 24). This locality was depositionally seaward from previous stops and, as a result, the Upper Mississippian section is marginally marine to marine. Coal beds are typically absent and Late Mississippian orthoquartzites have wedged out except for the Pinnacle Overlook Member which has thinned considerably. The distal or seaward ends of other orthoquartzite beds are represented by thin ripple-bedded sandstone units in the dark-gray Pride Shale Member of the Bluestone Formation. The dark-gray shale also includes locally abundant trace fossil and marine invertebrates of Late Mississippian age and was originally mapped as Upper Mississippian (Englund, 1968). Later studies (Potter and others, 1981) placed the Mississippian-Pennsylvanian boundary, with some uncertainty, at the base of the Pinnacle Overlook Member. This practice, based on the lithic similarity of the Pinnacle Overlook and Pride Shale Members to overlying Pennsylvanian rocks, follows a precedent set in a GQ map (Rice and Maughan, 1978) that extends across this outcrop belt to the northeast in Kentucky, where Pride Shale Member equivalents were also included in the Pennsylvanian. This misplacement of the systemic boundary demonstrates the difficulties of using 1 ithology, rather than biostratigraphy, to determine the age of rock units.

This section of Late Mississippian strata is useful also to demonstrate a variation in the use of the term - Pennington - in eastern Rentucky southward across Tennessee and into Georgia and Alabama. Instead of placing the base of the Pennington at the base of the Stony Gap Sandstone Member, as in the type locality, it is placed at the top of the Bangor or Greenbrier Limestone. Originally pointed out in 1968 (Englund, 1968, p. 12), this practice was remedied in Kentucky (Ettensohn and others, 1984) but continues to be used in the southern part of the basin. 


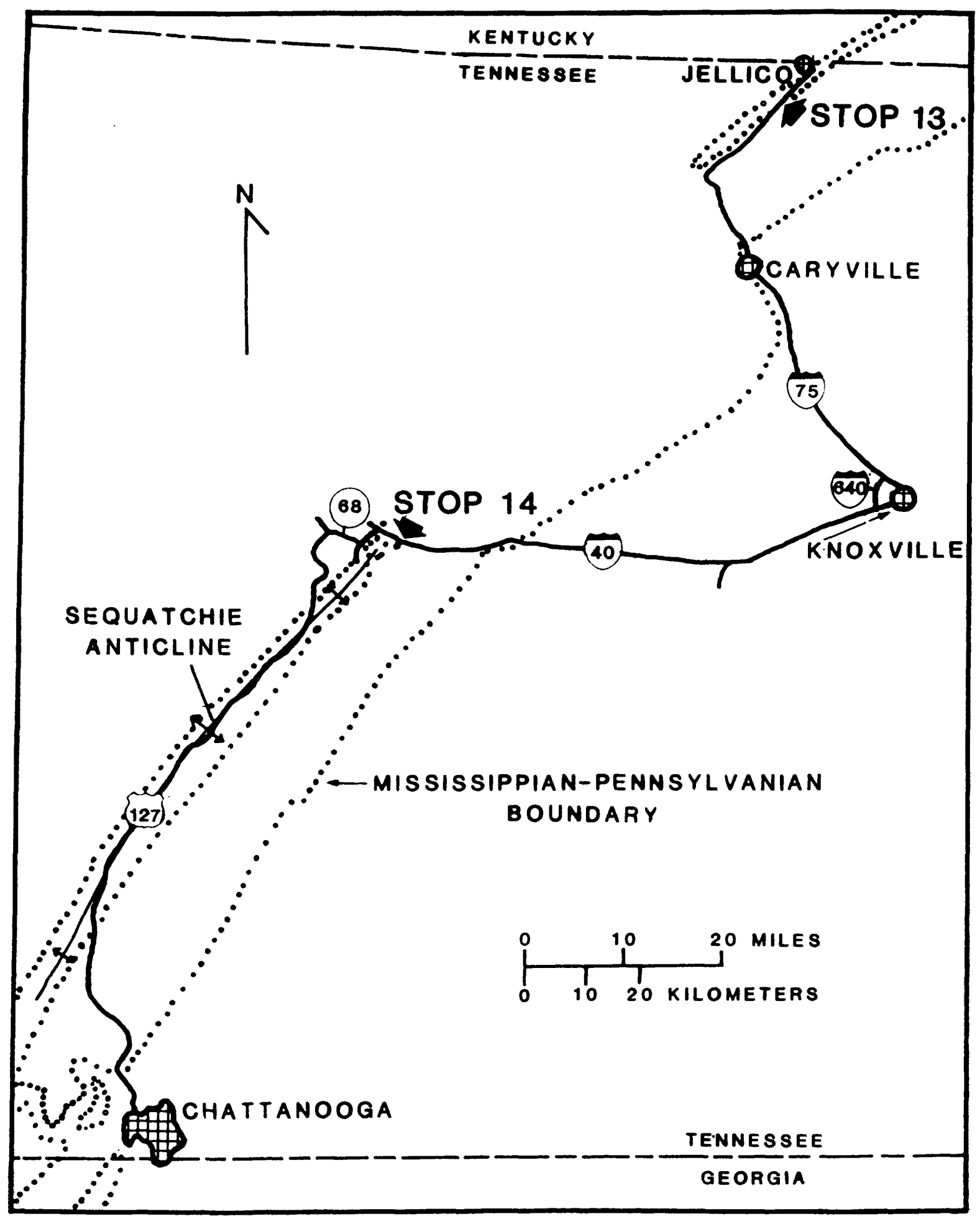

Figure 23. Route map showing third day Stops 13 and 14. 


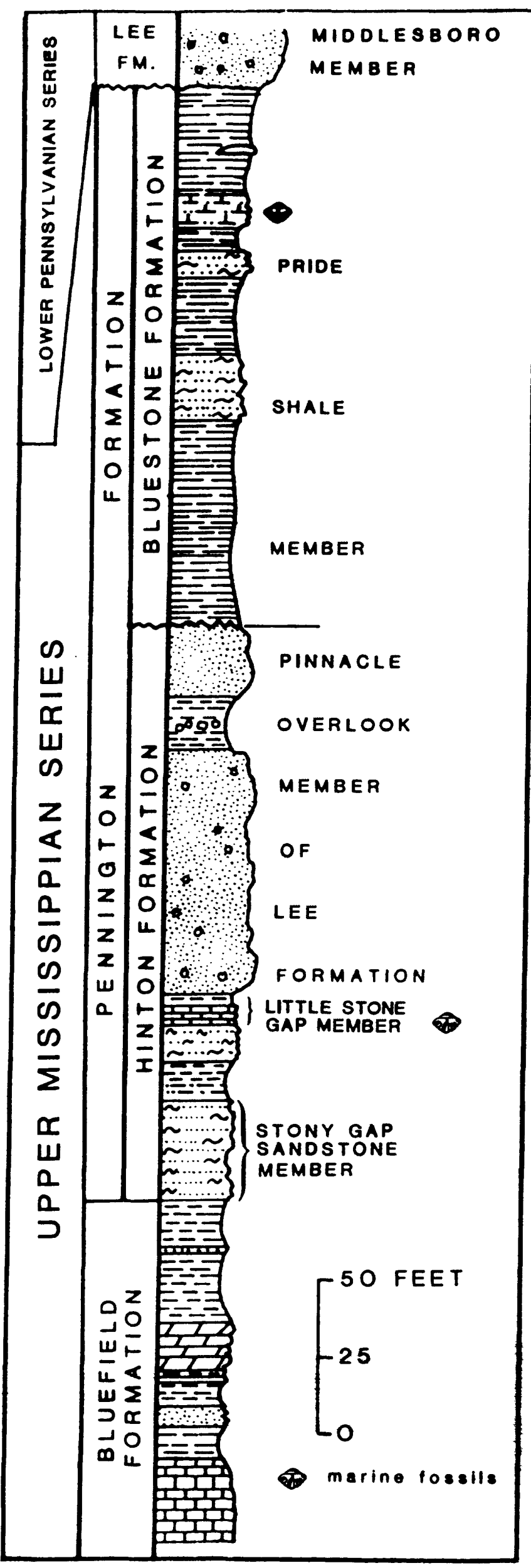

65

Figure 24. Strata exposed along Interstate-75 south of Jellico, 
Mileage - Continued

Cumulative Increment

Continue northbound on $\mathrm{I}-75$.

$25.32 .4 \quad$ Fort Payne Chert (Lower Mississippian) overlain by Greenbrier Limestone (Lower member of Newman Limestone) in cut on right.

$25.4 \quad 0.1 \quad$ Grainger Shale in cut on right.

$25.5 \quad 0.1 \quad$ Pine Mountain thrust fault.

$27.1 \quad 1.6 \quad$ Turn right at Jellico Exit 35 .

$27.7 \quad 0.6 \quad$ Turn left for reentry to I-75.

27.8 Access ramp to $I-75$ southbound. Route retraces the last $26 \mathrm{mi}$ along I-75 to Caryville, TN.

53.3 25.5 Caryville, TN. Continue southbound on I-75 through highly sheared, faulted, and folded Lower Paleozoic strata.

80.3 27.0 Knoxville, TN. Turn right on I-640 westbound.

83.3 $3.0 \quad$ Bear right on I-40-75. Route extends westward across belts of faulted Lower Paleozoic strata.

$100.3 \quad 17.0 \quad$ Bear right on $\mathrm{I}-40$.

$120.0 \quad 19.7$ Harriman, TN. Exit 347 . Continue ahead on I-40.

$123.0 \quad 3.0 \quad$ Greenbrier Limestone (Bangor) on right.

$124.6 \quad 1.6 \quad$ Hinton Formation (Pennington) on right.

$127.8 \quad 3.2 \quad$ Lower Pennsylvanian strata on right.

135.9 S.1 Splay thrusting along the toe of 0zone decollement (Harris and Milici, 1977).

$136.3 \quad 0.4 \quad$ Stop 14 .

CRAB ORCHARD SECTION

About $300 \mathrm{ft}$ of Upper Mississippian and Lower Pennsylvanian rocks on the southeast $1 \mathrm{imb}$ of the Sequatchie anticline are exposed at Stop 14 ( $\mathrm{fig}$. 25). Upper Mississippian strata were deposited in a marine environment located west of the terrestrial coal-bearing facies in this part of the section. Also of significance at this locality is the development of sparsely rooted paleosols just below the unconformity at the top of the Mississippian sequence. Similar paleosols typically occur at the systemic boundary along the relatively positive western flank of the Appalachian basin including extensive residual 


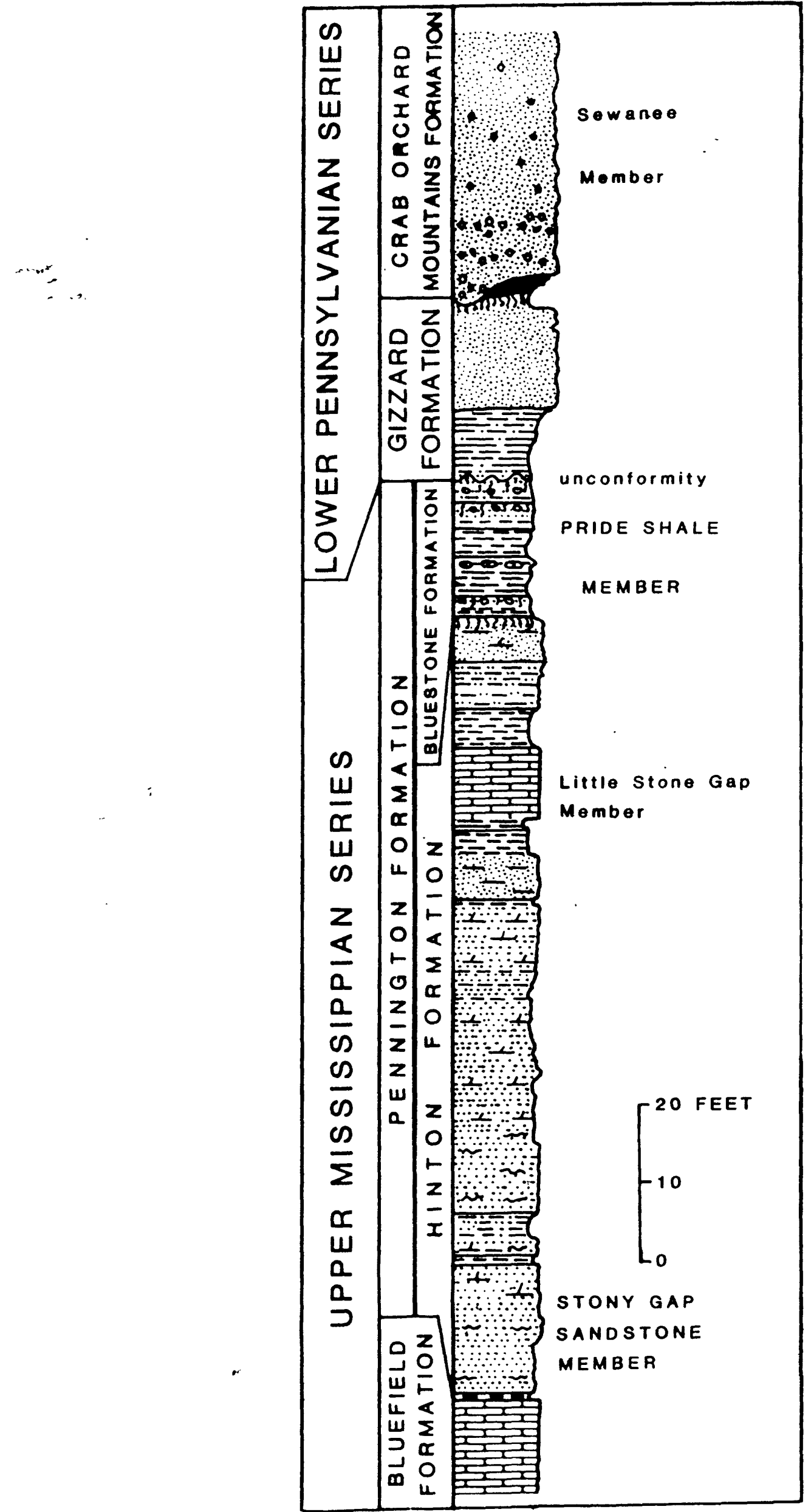

Figure 25. Strata exposed along Interstate-40 east of Crab Orchard. Tennessee at Stop 14. 
deposits of flint clay in eastern Kentucky. At Stop 14 there may have been some local syntectonic activity along the Sequatchie anticline as indicated by the obvious angular disconformity between strata of Mississippian and Pennsylvanian age ( $\mathrm{fig} .26$ ). The base of this section includes about $20 \mathrm{ft}$ of 1 imestone, identified as the Bangor by Harris and Milici (1977), that is herein correlated with the Bluefield Formation. The overlying ripple-bedded sandstone is correlated with the Stony Gap Sandstone Member of the Hinton Formation and about $15 \mathrm{ft}$ of fossiliferous, coarsely crystalline limestone in the upper part of the formation is an excellent correlative for the Little Stone Gap Member. Uppermost beds of the Mississippian consist of sideritic shale and siltstone that were subjected to subaerial exposure as indicated by deeply weathered and rooted paleosols. - Biostratigraphic data indicate that overlying Pennsylvanian units are middle or upper New River equivalents and that the basal Pennsylvanian equivalent or Pocahontas Formation is absent.

Mileage - Continued

Cumulative Increment

\begin{tabular}{|c|c|c|}
\hline 137.3 & 1.0 & Greenbrier Limestone (Monteagle and Bangor) on right. \\
\hline 138.2 & 0.9 & $\begin{array}{l}\text { Crab Orchard, Exit } 329 \text {, turn right on access ramp and } \\
\text { then left onto US } 70 \text { westbound. }\end{array}$ \\
\hline 140.0 & 1.8 & Turn left on County Road R5098. \\
\hline 141.3 & 1.1 & Sand pit on left. \\
\hline 142.4 & 1.1 & Abandoned strip mine in sewanee coal bed on right. \\
\hline 142.6 & 0.2 & Sand pit on left. \\
\hline 143.4 & 0.8 & Turn right on State Route 68 . \\
\hline 147.5 & 4.1 & Homestead, TN. Turn left on US 127 . \\
\hline 157.7 & 10.2 & Hinton Formation (Pennington) on right. \\
\hline 158.1 & 0.4 & $\begin{array}{l}\text { Greenbrier Limestone (Bangor) on right. Route } \\
\text { extends southwestward for the next } 40 \mathrm{mi} \text { in mostly } \\
\text { Ordovician to Mississippian carbonate strata exposed } \\
\text { along the crest of the Sequatchie anticline. Lower } \\
\text { Pennsylvanian orthoquartzite caps ridges on both } \\
\text { sides of the Sequatchie Valley. }\end{array}$ \\
\hline 217.7 & 59.6 & $\begin{array}{l}\text { Chat tanooga, TN. Turn right on I-124 to I- } 24 \\
\text { eastbound. }\end{array}$ \\
\hline 224.1 & 6.4 & Chat tanooga, TN. \\
\hline
\end{tabular}



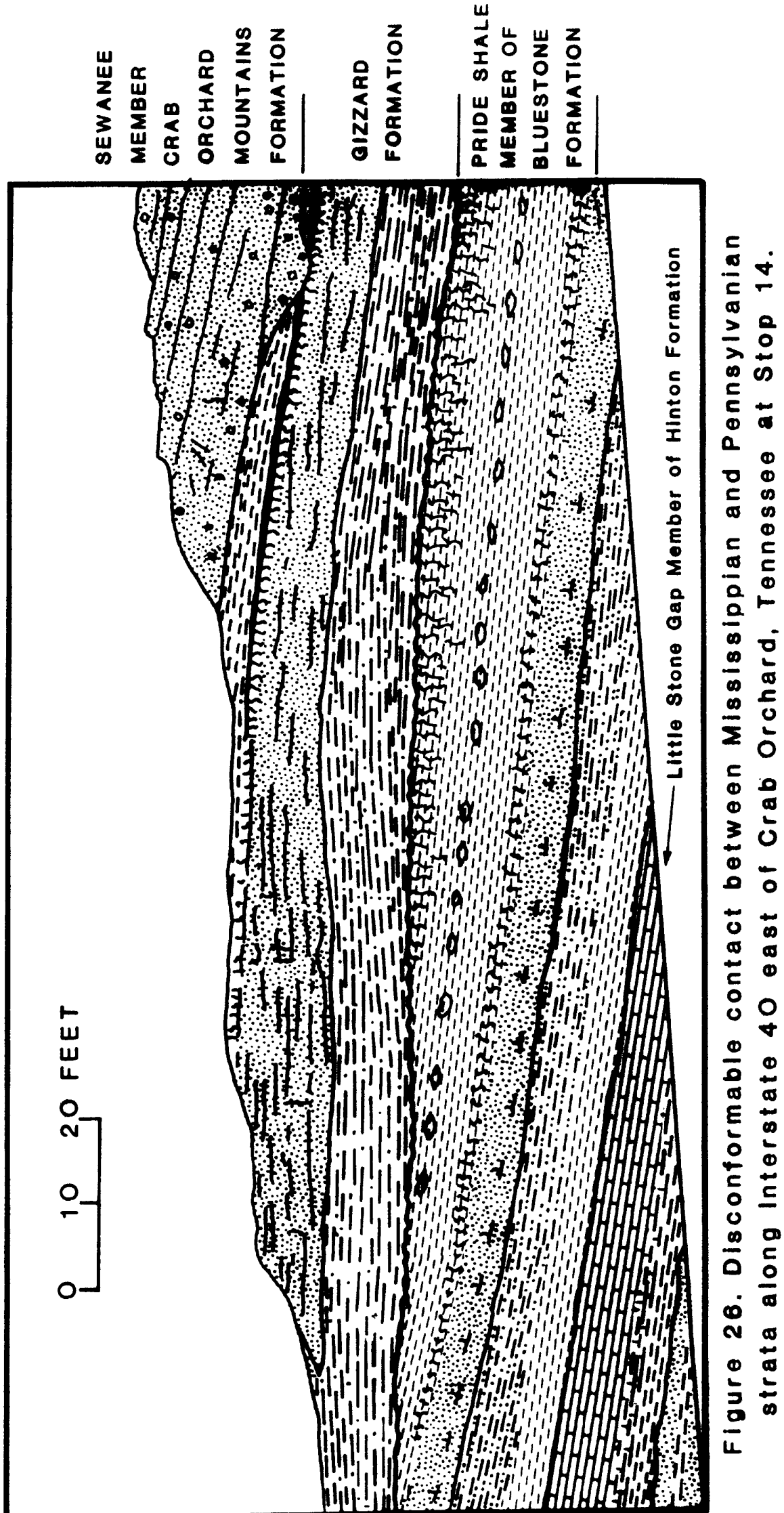

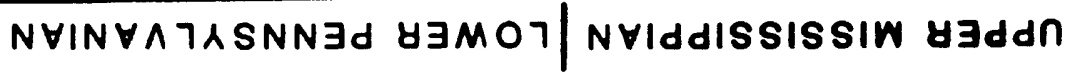




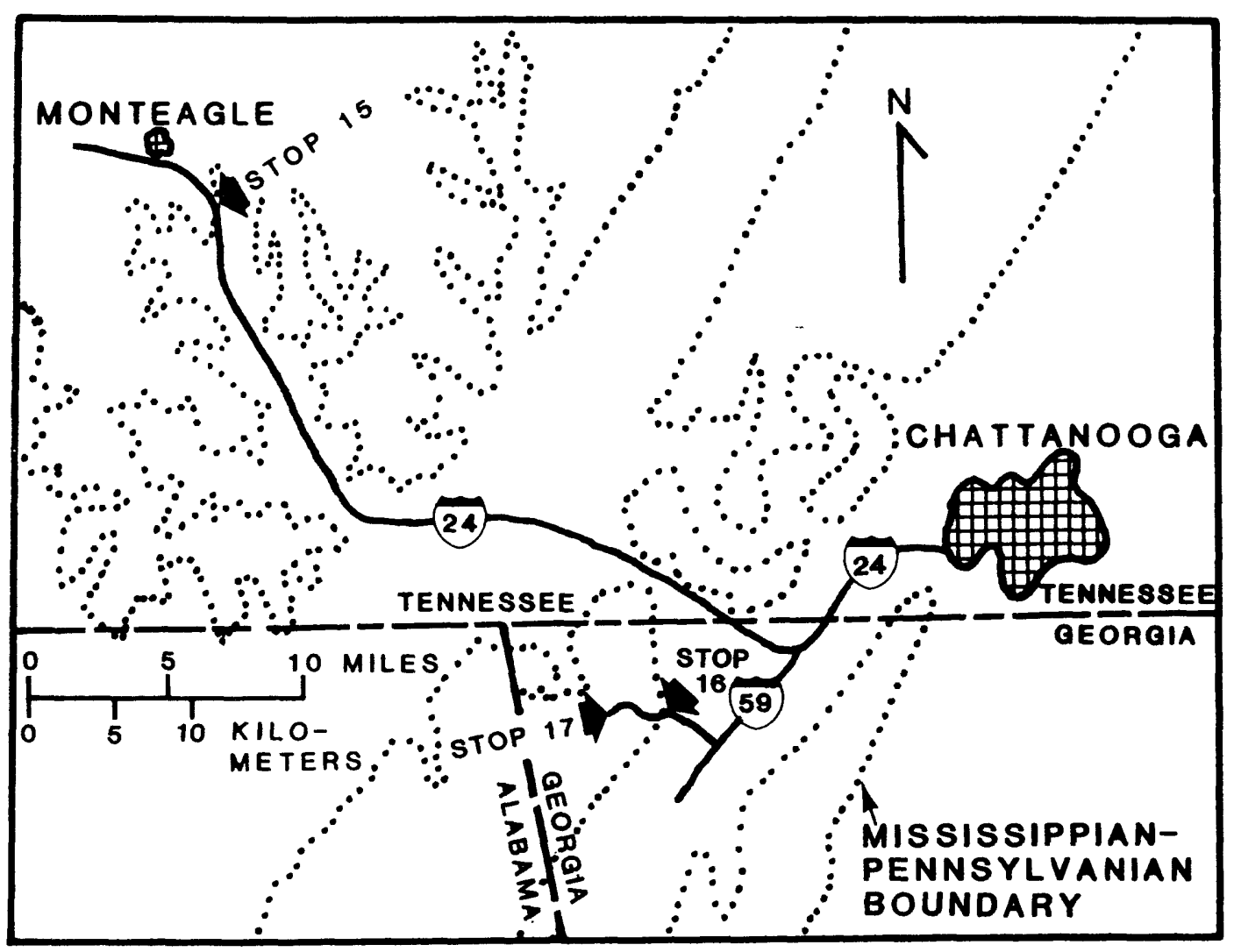

Figure 27. Route map showing fourth day stops 15-17. 
ROAD LOG AND STOP DESCRIPTIONS

CHATTANOOGA AREA

\begin{tabular}{|c|c|c|}
\hline $\begin{array}{l}\text { Mileage } \\
\text { Cumulative }\end{array}$ & Increment & \\
\hline 0.0 & 0.0 & Depart Chattanooga, TN. Turn right on E. 23 rd St. \\
\hline 0.1 & 0.1 & Turn right on 4 th Avenue. \\
\hline 0.2 & 0.1 & $\begin{array}{l}\text { Turn right on access route to } \mathrm{I}-24 \text { westbound (fig. } \\
27 \text { ). }\end{array}$ \\
\hline 2.4 & 2.2 & $\begin{array}{l}\text { Junction with I-124. Continue in left lane on I- } 24 \\
\text { toward Nashville. }\end{array}$ \\
\hline 9.2 & 6.8 & Quarry on left in Monteagle Limestone. \\
\hline 13.0 & 3.8 & Junction with I-59, bear right on I-24. \\
\hline 31.9 & 18.9 & Quarry on right in Monteagle Limestone. \\
\hline 44.0 & 12.1 & Stop 15 . \\
\hline
\end{tabular}

MONTEAGLE SECTION

The stratigraphy and depositional environments of Carboniferous rocks exposed at Stop 15 have been described in detail by Bergenback and others (1980). The sequence, of Late Mississippian age, was depositionally seaward from correlatives at previous stops and, as a result, consists entirely of marine limestone and shale (fig. 28). Of the viewed sequences, the Monteagle section is also situated farthest to the west where regional erosion or down-cutting along the Lower Pennsylvanian unconformity is greatest. Equivalents of the Pocahontas, Bluestone, and Hinton Formations are absent and strata previously designated Pennington Formation are most likely Bluefield equivalents.

Mileage - Continued

Cumulative Increment

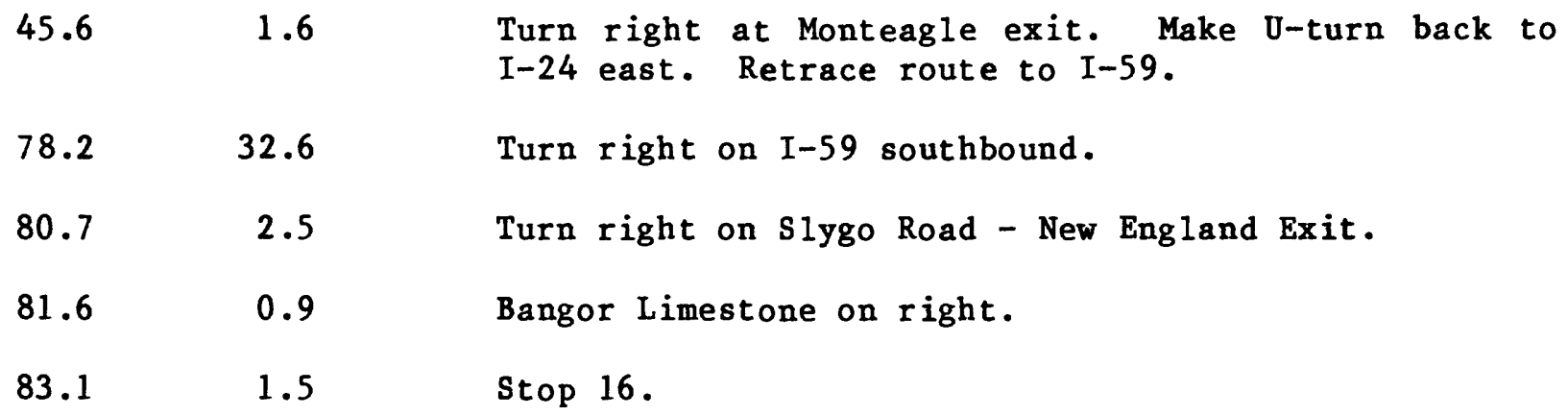




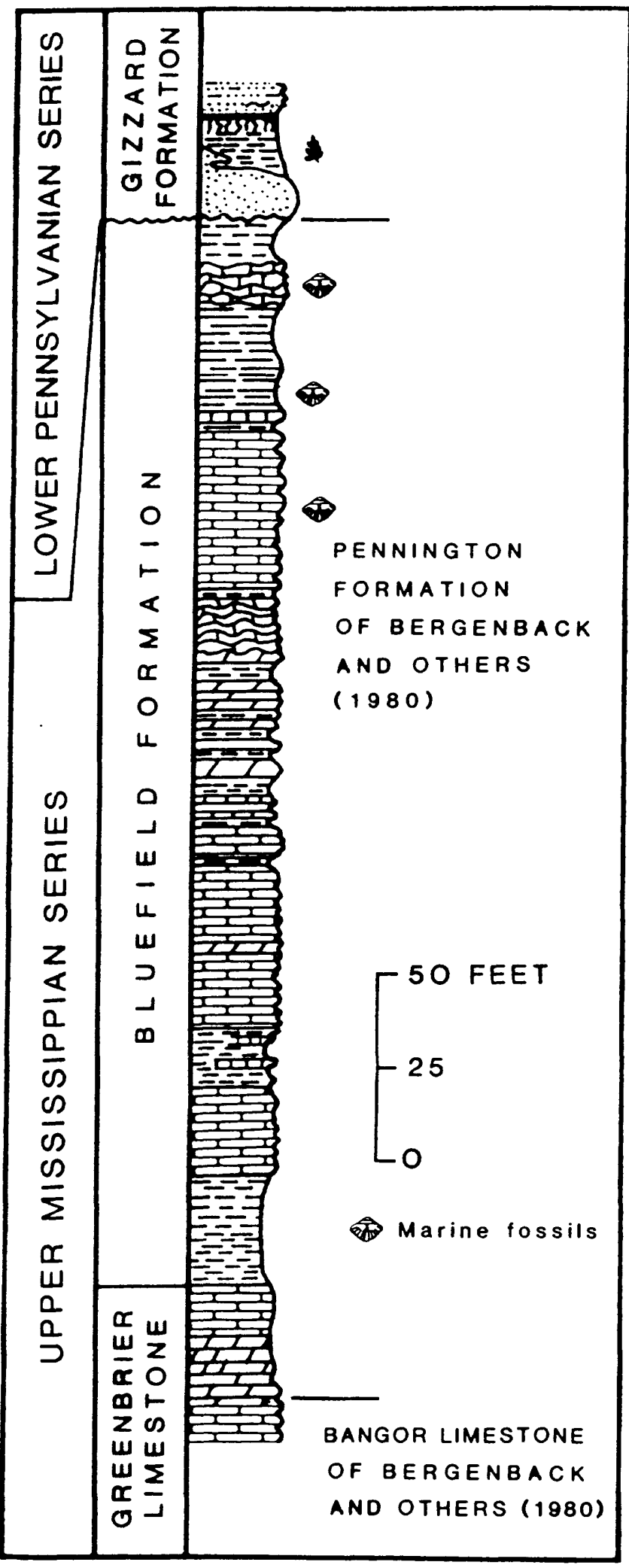

Figure 28. Monteagle section. Part of Upper Mississippian and Lower Pennsylvanian sequence exposed on Interstate 24 at Monteagle.

Tennessee at Stop 15. 


\section{HALE GAP SECTION}

Upper Mississippian and Lower Pennsylvanian rocks at Hale Gap are on the gently dipping southeast $1 \mathrm{imb}$ of the Sand Mountain syncline in northwestern Georgia ( $f i g .3$ ). Strata identified as the Penningt on are much thicker than at Stop 15 and include correlatives of the Bluefield, Hinton, and Bluestone Formations. The Bluefield is represented by a sequence of poorly exposed 1 imestone and shale that occupies a 300-ft interval between the Bangor Limestone and a cliff-forming, ripple-bedded sandstone at the base of stop 16. This highly resistant sandstone thins locally and grades to thin-bedded sandstone with interbeds of siltstone and shale. It is at the stratigraphic position of the Stony Gap Sandstone Member of the Hinton Formation. An overlying dark-gray shale in the upper part of the Pennington at Hale Gap is correlated with the Pride Shale Member of the Bluestone on the basis of its lithology, stratigraphic position, and fossil content. Like the Pride Shale Member, it contains plant fossils as well as fresh-water and marine invertebrates. The flora is especially important as it is one of the best found in this sequence. It contains Archaeopteriduim tschermachei and Rhodeopteridium stachei, both indicative of a Late Mississippian age. In addition, the flora includes abundant Trigonocarpalian seeds, Aphlebia, Sphenopteris sp., and a new genus that probably belongs to the progymosperms. Marine invertebrates in this unit are also Late Mississippian (Chesterian) in age.

The Mississippian-Pennsylvanian boundary is overlain by a coal-bearing sequence consisting largely of sandstone, siltstone, shale, and underclay assigned to the Raccoon Mountain Member of the Gizzard Formation. The oldest of several coal beds in the member is the No. 11 or Mill Creek coal bed which consists of 6-12 in. of coal about $15 \mathrm{ft}$ above the systemic boundary. Plant fossils indicate that the coal-bearing sequences in northwestern Georgia is late Early Pennsylvanian in age similar to the New River Formation in the Pennsylvanian System stratotype. Although the underlying Upper Mississippian sequence is essentially complete, a hiatus is indicated by the absence of beds containing the lower Early Pennsylvanian Pocahontas flora. This relationship concurs with the regional trend observed to the north in Virginia and West Virginia where the Pocahontas Formation was truncated prior to the erosion of underlying beds of Late Mississippian age. Also, in agreement with regional trends, increased terrestrial influence to the southeast in Late Mississippian time is supported by the presence of nearshore and plant-bearing beds in the Hale Gap section.

Mileage - Continued

Cumulative Increment

$\begin{array}{lll}83.9 & 0.8 & \text { Intersection, continue westbound on Slygo Road. } \\ 84.2 & 0.3 & \text { Stop } 17 .\end{array}$

PULLEN COAL MINE

The No. 8 (Etna) and No. 9 (Dade) coal beds in the Raccoon Mountain Member of the Gizzard Formation are the two most extensively mined beds at the north end of Sand Mountain (fig. 3). The Pullen Coal Mine of the Jackson County 
Mining Corporation is a strip mine operating primarily in the No. 9 coal bed. The coal is of medium-volatile bituminous rank and company records indicate that this bed averages approximately $20 \mathrm{in.}$ in thickness. Analyses of samples from six localities in the mine show that, on an as-received basis, the average ash content is 3.33 percent, the average sulfur content is 1.07 percent, and the average calorific value is $14,333 / 1 \mathrm{~b}$. Underground mining of the No. 9 coal bed was severely hampered by unstable roof conditions, pinch outs, rolls, and smal1-scale faulting. As a result, the bed was not considered to be mineable until modern earthmoving equipment became available.

The No. $8 \mathrm{coal}^{-}$bed is of similar quality as the No. 9 but is only locally of mineable thickness. Significant areas of the No. 8 coal bed were eroded prior to the deposition of the overlying Warren Point Member of the Gizzard Formation. Because of coal bed characteristics in the Sand Mountain area, extensive exploratory drilling is required for successful mining operations.

Mileage - Continued

Cumulative Increment

Retrace route back to I-59.

$\begin{array}{rrr}87.8 & 3.5 & \text { Turn left on I-59 northbound. } \\ 90.2 & 2.5 & \text { Turn right on I-24 eastbound. } \\ 109.4 & 19.2 & \text { Turn left on I-75 northbound. } \\ 112.1 & 2.7 & \text { Turn left on State Route } 153 . \\ 114.1 & 2.0 & \text { Chattanooga Airport. }\end{array}$

Fnd of Trip

\section{Acknowledgements}

We wish to acknowledge the many contributions made by previous field trips in the area of this excursion. Among these, lithostratigraphic and biostratigraphic data were provided by: 1) Bergenback and others (1980) in the Chattanooga area; 2) Harris and Milici (1977) along the traverse across Tennessee; 3) Englund and Harris (1961) in the Cumberland Gap area; and 4) Cooper (1961) and Englund and others $(1977,1979)$ in the Pennsylvanian System stratotype study area of southern West Virginia and southwestern Virginia. The cooperation of the Jackson County Mining Corporation and Mr. William H. Pullen in connection with the visit to the Pullen Mine is sincerely appreciated. Special thanks are due Roger $E$. Thomas for his assistance in the preparation of guidebook illustrations. 


\section{REFERENCES CITED}

Beerbower, J.R., 1964, Cyclothems and cyclic depositional mechanisms in alluvial plain sedimentation: Kansas State Geological Survey, Bulletin 169 , v. 1 , p. 32-42.

Bergenback, R.E., Wilson, R.L., and Rich, Mark, 1980, Carboniferous paleodepositional environments of the Chattanooga area, in Frey, R.W., ed., (Geological Society of America Annual Meeting guidebook, v. 1, Excursions in southern geology, field trip 13): Washington, D.C., American Geological Institute, p. 259-278.

Bertrand, P., 1934, Les flores houilleres d'Amerique d' apres les travaux de M. David White: Societe Geologique Nord, Ann., v. 58, p. 231-254 [1933].

1935, Nouvelles correlations stratigraphiques entre le Carbonifere occidentale d'apres MM. Jongmans et Gothan: Societe Geologique Nord, Ann., v. 60 , p. 3-16.

Bode, Hans, 1958, Die floristische Gliederung des Oberkarbons der Vereinigten Staaten von Nordamerika: Deutsche Geol. Gesell., Zeitschr., v. 110, pt. 2, p. 217-259.

Bouroz, A., Einor, O.L., Gordon, M., Jr., Meyen, S.V., and Wagner, R.H., 1978, Proposals for an international chronostratigraphic classification of the Carboniferous: Eighth International Congress of Carboniferous Stratigraphy and Geology, Compte Rendu, v. 1, Moscow, 1975, p. 36-69.

Busch, R.M., and Rollins, H.B., 1984, Correlation of Carboniferous strata using a hierachy of transgressive-regressive units: Geology, v. 12, p. 471-474.

Campbell, M.R., 1893, Geology of the Big Stone Gap coal field of Virginia and Kentucky: U.S. Geological Survey Bulletin 111, 106 p.

Cecil, C.B., Stanton, R.W., Neuzil, S.G., Dulong, F.T., Ruppert, L.F., and Pierce, B.S., 1985, Paleoclimate controls on Late Paleozoic sedimentation and peat formation in the central Appalachian basin (U.S.A.), in Phillips, T.L., and Cecil, C.B., eds., Paleoclimatic controls on coal resources of the Pennsylvanian System of North America: International Journal of Coal Geology, v. 5, p. 195-230.

Coleman, J.M., Gagliano, S.M., and Smith, W.G., 1970, Sedimentation in a Malaysian high tide tropical delta, in Morgan, J.P., ed., Deltaic sedimentation, modern and ancient: Society of Economic Paleontologists and Minerologists Special Publication No. 15, p. 185-197.

Cooper, B.N., 1961, Grand Appalachian field excursion, Field trip 1 of Geological Society America Annual Meeting, Cincinnati, Ohio: Virginia Polytechnic Institute Engineering Extension Series Geological guidebook 1, $187 \mathrm{p}$.

Cramer, H.R., 1979, Pennsylvanian stratigraphy of northwest Georgia: U.S. Geological Survey Professional Paper 1110-A-L, p. H19-H37. 
Culbertson, W.C., 1963, Pennsylvanian nomenclature in northwest Georgia: U.S. Geological Survey Professional Paper 450 E, p. E51-E57.

Dietz, R.S., 1966, Shatter cones at the Middlesboro structure, Kentucky: Meteoritics, v. 3, no. 1, p. 27-29.

Donaldson, A.C., Renton, J.J., and Presley, M.W, 1985, Pennsylvanian deposystems and paleoclimates of the Appalachians, in Phillips, T.L., and Cecil, C.B., eds., Paleoclimatic controls on coal resources of the Pennsylvanian System of North America: International Journal of Coal Geology, v. 5, p. 167-193.

Donaldson, A.C., and Schumaker, R.C., 1979, Late Paleozoic molasse of the central Appalachians, in Donaldson, A.C., Presley, M.W., and Renton, J.J., eds., Carboniferous coal short course and guidebook: West Virginia Geological and Economic Survey Bulletin B-37-3, p. 1-42.

Englund, K.J., 1968, Geology and coal resources of the Elk Valley area, Tennesee and Kentucky: U.S. Geological Survey Professional Paper 572, $59 \mathrm{p}$.

1974, Sandstone distribution patterns in the Pocahontas Formation of southwest Virginia and southern West Virginia, in Briggs, Garrett, ed., Carboniferous of the southeastern United States: Geological Society of America Special Paper 148, p. 31-45.

Englund, K.J., Arndt, H.H., Gillespie, W.H., Henry, T.W., and Pfefferkorn, H.W., 1977, A field guide to the proposed Pennsylvanian System Stratotype, West Virginia: (American Association of Petroleum Geologists Annual Meeting Guidebook, Field trip 2) Washington, D.C., 80 p.

Englund, K.J., Arndt, H.H., and Henry, T.W., eds., 1979, Proposed Pennsylvanian System Stratotype, Virginia and West Virginia (Ninth International Congress of Carboniferous Stratigraphy and Geology Meeting Guidebook Field trip 1): Washington, D.C., American Geological Institute, 136 p.

Englund, K.J., and DeLaney, A.0., 1966, Intertonguing relation of the Lee Formation in southwestern Virginia: U.S. Geological Survey Professional Paper 550-D, P. D47-D52.

Englund, K.J., Gillespie, W.H., Johnson, P.L., and Pfefferkorn, H.W., in press, Depositional model for Upper Mississippian and Lower Pennsylvanian coal-bearing rocks of southwestern Virginia: in McDowell, R.C., and Glover, Lynn, III, eds., Studies in Appalachian Geology: Virginia Polytechnic Institute and State University, Department of Geological Sciences Memoir 3.

Englund, K.J., and Harris, L.D., 1961, Itinerary--Geologic features of the Cumberland Gap area, Kentucky, Tennessee, and Virginia: Geological Society of Kentucky Field Trip guidebook, 30 p.

Englund, K.J., and Henry, T.W., 1981, Mississippian-Pennsylvanian boundary in the central part of the Appalachian basin, Part 1: Southwestern Virginiasouthern West Virginia in Roberts, T.G., ed., (Geological Society of 
America, Annual Meeting Guidebook, v. 1, field trip 4, Stratigraphy, sedimentology): Washington, D.C., American Geological Institute, p. 153-194.

Englund, K.J., and Randal1, A.H., III, 1981, Stratigraphy of the Upper Mississippian and Lower Pennsylvanian Series in the east-central Appalachians in Roberts, T.G., ed., (Geological Society of America Annual Meeting Guidebook, v. 1, field trip 4, Stratigraphy, sedimentology): Washington, D.C., American Geological Institute, p. 154-158.

Englund, K.J., and Roen, J.B., 1963, Origin of the Middlesboro Basin, Kentucky: U.S. Geological Survey Professional Paper 450-E, P. E20-E22.

Englund, K.J., and Smith, H.L., 1960, Intertonguing and lateral gradation between the Pennington and Lee Formations in the Tri-State area of Kentucky, Tennessee, and Virginia [abs.]: Geological Society of America Bulletin, v. 71, No. 12, p. 2015.

Englund, K.J., and Windolph, J.F., Jr., 1971, Geology of the Carter Caves Sandstone (Mississippian) in northeastern Kentucky: U.S. Geological Survey Professional Paper 750-D, P. D99-D104.

Englund, K.J., Windolph, J.F., Jr., and Thomas, R.E., 1984, Deposition of lowsulfur coal in the Lower Pennsylvanian Pocahontas Formation, Virginia and West Virginia: Geological Society of America Abstracts with Programs, 1984 Annual Meeting, p. 502.

Englund, K.J., Windolph, J.F., Jr., Weber, J.C., Thomas, R.E., and Dryden, J.W., 1983, Test drilling for coal in 1982-83, in the Jefferson National Forest, Virginia, Part I: Lithologic descriptions and geophysical logs of coreholes in the southwestern Virginia coal field, Dickenson, Lee, Scott, and Wise Counties, Virginia: U.S. Geological Survey Open-File report OF-83-628, $374 \mathrm{p}$.

Ettensohn, F.R., 1977, Effects of synsedimentary tectonic activity on the upper Newman Limestone and Pennington Formation in Dever, G.R., Jr., Hoge, H.P., Hester, N.C., and Ettensohn, F.R., Stratigraphic evidence for late Paleozoic tectonism in northeastern Kentucky (American Association of Petroleum Geologist Eastern Section Meeting guidebook) Rentucky Geological Survey, p. 18-29.

1979, Generalized description of Carboniferous stratigraphy, structure and depositional environments in east-central Kentucky, in Ettensohn, F.R., and Dever, G.R., Jr., eds., Carboniferous geology from the Appalachian Basin to the Illinois Basin through eastern Ohio and Kentucky (Ninth International Congress of Carboniferous Stratigraphy and Geology Meeting Guidebook field trip 4) University of Kentucky, 293 p.

Etternsohn, F.R., and Dever, G.R., Jr., 1975, Tectonic control of carbonate sedimentation in the Newman Group (middle and late Mississippian), northeastern Kentucky: American Association of Petroleum Geologists Annual Meetings Abstract s, v. 2, p. 22-23. 
Ettensohn, F.R., and Peppers, R.A., 1979, Palynology and biostratigraphy of Pennington shales and coals (Chesterian) at selected sites in northeastern Kentucky: Journal of Paleontology, v. 53, p. 453-474.

Ettensohn, F.R., Rice, C.L., Dever, G.R., Jr., and Chesnut, D.R., 1984, Slade and Paragon Formations - New stratigraphic nomenclature for Mississippian Rocks along the Cumberland escarpment in Kentucky: U.S. Geological Survey Bulletin $1605,37 \mathrm{p}$.

Ferm, J.C., 1974, Carboniferous enviromental models in eastern United States and their significance, in Briggs, Garrett, ed., Carboniferous of the southeastern United States: Geological Society of America Special Paper 148 , p. 49-95.

Ferm, J.C., and Ehrlich, R., 1967, Petrology and stratigraphy of the Alabama coal fields, in Ferm, J.C., Ehrlich, R., and Neathery, T.L., A field guide to Carboniferous detrital rocks in northern Alabama: (Geological Society of America Coal Division Annual Meeting guidebook) Alabama Geological Society, p. 11-15.

Ferm, J.C., Horne, J.C., Swinchatt, J.P., and others, 1971, Carboniferous depositional environments in northeastern Kentucky: Geological Society of Kentucky Annual Spring Field Conference, Guidebook, Kentucky Geological Survey, $30 \mathrm{p}$.

Gillespie, W.H., and Crawford, T.A., 1983, Plant megafossils from the Carboniferous of Georgia, U.S.A.: Tenth International Congress of Carboniferous Stratigraphy and Geology, Abstracts, Madrid, Spain, p. 100.

Gillespie, W.H., Crawford, T.A., Eble, C.F., 1985a, Plant biostratigraphy of the coals of Georgia (Pottsville, Pennsylvanian): [abs.], Proceedings of the West Virginia Academy of Sciences, v. 57 (1), p. 22.

Gillespie, W.H., and Pfefferkorn, H.W., 1977, Plant fossils and biostratigraphy at the Mississippian/Pennsylvanian boundary in the Pennsylvanian System stratotype area, West Virginia/Virginia: Botanical Society of America Annua 1 Meeting Abstracts of Papers, p. 37.

1979a, Distribution of commonly occurring plant megafossils in the proposed Pennsylvanian System stratotype in Englund, K.J., Arndt, H.H., and Henry, T.W., eds., Proposed Pennsylvanian System stratotype, Virginia and West Virginia, (Ninth International Congress of Carboniferous Stratigraphy Meeting Guidebook field trip 1): Washington, D.C., American Geological Institute, $136 \mathrm{p}$.

1979b, Paleobotany in Arkle, Thomas, Jr., Beisel, D.R., Larese, R.E., Nuhfer, E.B., Patchen, D.G., Smosna, R.A., Gillespie, W.H., Land, Richard, Norton, C.W., and Pfefferkorn, H.W., The Mississippian and Pennsylvanian (Carboniferous) Systems in the United States--West Virginia and Maryland: U.S. Geological Survey Professional Paper 1110-D, p. D30-D31.

Gillespie, W.H., Rheams, L.J., Barnett, Larry, and Eble, C.F., 1985b, Plant biostratigraphy of the coals of Alabama (Pottsville, Pennsylvania): [abs.], Proceedings of the West Virginia Academy of Science, v. 57 (1) p. 20 . 
Gordon, Mackenzie, Jr., and Henry T.W., 1981, Late Mississippian and Early Pennsylvanian invertebrate faunas, east-central Appalachians-A preliminary report, in Roberts, T.G., ed., (Geological Society of America Annual Meeting Guidebook, v. 1, field trip 4, Stratigraphy, sedimentology): Washington, D.C., American Geological Institute, p. 165-171.

Gothan, Wa1ther, 1952, Der "Florensprung" and die "Erzgebirgische Phase" Kossmats: Geologica, Berlin, no. 11, p. 41-49.

Haney, D.C., 1979, The Mississippian-Pennsylvanian systemic boundary in eastern Rentucky: Southeastern Geology, v. 21, no. 1, p. 53-62.

Harris, L.D., and Milici, R.C., 1977, Characteristics of thin-skinned style of deformation in the southern Appalachians, and potential hydrocarbon traps: U.S. Geological Survey Professional Paper 1018, 40 p.

Havlena, Vaclav, 1982, The Namurian of Upper Silesia: flora breaks, midCarboniferous boundary problem: in Ramsbottom, W.H.C., Saunders, W.B., and Owens, Bernard, eds., Biostratigraphic data for a mid-Carboniferous boundary, Leeds, England Meeting of Subcommission on Carboniferous Stratigraphy, p. 112-119.

Hem, J.D., 1970, Study and interpretation of the chemical characteristics of natural water: U.S. Geological Survey Water Supply Paper 1473, 363 p.

Hennen, R.V., and Gawthrop, R.M., 1915, Wyoming and McDowe1l Counties: West Virginia Geological Survey [County Report], 783 p.

Henry, T.W., Gillespie, W.H., Gordon, Mackenzie, Jr., and Schweinfurth, S.P., 1981, Stratigraphic significance of plant and invertebrate fossils from Parkwood Formation, Northern Alabama: Geological Society of America Abstracts with Programs, v. 13, no. 7, p. 471.

Hillen, Roeland, 1984, Tropical lowland peats: characteristics, genesis, and applications: Conference on applications of geology and the national development, Chwbalongkorn University, Bankok, p. 361-371.

Horne, J.C., 1979, The orthoquartzite problem in Ferm, J.C., Horne, J.C., Weisenfluh, G.A., and Staub, J.R., eds., Carboniferous depositional environments in the Appalachian region [Collected papers] Columbia, South Carolina, University of South Carolina, p. 370.

Horne, J.C., and Ferm, J.C., 1970, Facies relationships of the MississippianPennsylvanian contact in northeastern Kentucky: Geological Society of America Abstracts with Programs, v. 2, no. 3, p. 217.

Horne, J.C., Ferm, J.C., and Swinchatt, J.P., 1974, Depositional model for the Mississippian-Pennsylvanian boundary in northeastern Kentucky, in Briggs, Garrett, ed., Carboniferous of the southeastern United States: Geological Society of America Special Paper 148, p. 97-114.

Horne, J.C., Swinchatt, J.P., and Ferm, J.C., 1971, Lee-Newman barrier shoreline model in Ferm, J.C., Horne, J.C., Swinchatt, J.P., and Whaley, P.W. eds., Carboniferous depositional environments in northeastern Kentucky: Kentucky Geological Survey, p. 5-9. 
Houseknecht, D.W., 1980, Comparative anatomy of a Pottsville 1ithic arenite and quartz arenite of the Pocahontas basin southern West Virginia: Petrogenetic, depositional, and stratigraphic implications: Journal of Sedimentary Petrology, v. 50, no. 1, p. 20-30.

Jennings, J.R., 1970, Preliminary report on fossil plants from the Chester Series (Upper Mississippian) of Illinois: Illinois State Academy of Science, Transactions, v. 63, no. 2 , p. 167-177.

Jongmans, W.J., 19337, Contribution to a comparison between the Carboniferous floras of the United States and of western Europe: II Congr. Stratigr. Geol. Carbonifere, Compte Rendu, v. 1, Heerlen, 1935, p. 363-392.

Jongmans, W.J., and Gothan, Walther, 1934, Florenfoige and vergleichende Stratigraphie des Karbons der ostlichen Staaten Nord-Amerikas, Vergleich mit West-Europa: Geol. Bureau, Heerlen, Jarr-Verslag, 1933, p. 17-44.

Jongmans, W.J., Gothan, Walther, and Darrah, W.C., 1937, Comparison of the floral succession in the Carboniferous of West Virginia with Europe: II Conger. Stratigr. Geol. Carbonifere, Compte Rendu, v. 1, Heerlen, 1935, p. 393-415.

Keller, G.H., and Richards, A.F., 1967, Sediments of the Malacca Strait, southeast Asia: Journal of Sedimentary Petrology, v. 37, no. 1, p. 102-127.

Kidston, Robert, 1923, Fossil plants of the Carboniferous rocks of Great Britain: Great Britain Geological Survey Memoir, v. 2, pt. 1, p. 10.

Lianda, Gao, 1984, Carboniferous spore assemblages in China: in, Sutherland, P.K., and Manger, W.L., eds., Compte Rendu, Neuvieme Congres International de Stratigraphie et de Geologie du Carbonifere, v. 2, p. 103-108.

Meissner, C.R., Jr., and Miller, R.L., 1981, Geologic map of the Honaker quadrangle, Russel1, Tazewell, and Buchanan Counties, Virginia: U.S. Geological Survey Geologic Quadrangle Map GQ-1542, scale, 1:24,000.

Metzger, W.J., 1965, Pennsylvanian stratigraphy of the Warrior Basin: Geological Survey of Alabama Circular $30,80 \mathrm{p}$.

Miller, A.M., 1919, The geology of Kentucky: Kentucky Department of Geology and Forestry, series 5, Bulletin 2, 392 p.

Miller, M.S., 1974, Stratigraphy and coal beds of upper Mississippian and lower Pennsylvanian rocks in southwestern Virginia: Virginia Division of Mineral Resources Bulletin 84, 211 p.

Miller, R.L., 1969, Pennyslvanian Formation of southwest Virginia: U.S. Geological Survey Bulletin 1280, 62 p.

Moore, R.C., Elias, M.R., and Newell, N.D., 1936, A "Permian" flora from the Pennsylvanian rocks of Kansas: Journal of Geology, v. 44, no. 1, p. 1-31. 
Owens, Bernard, 1984, Miospore zonation of the Carboniferous: in Sutherland, P.R., and Manger, W.L., eds., Compte Rendu, Neuvieme Congres International de Stratigraphie et de Geologie du Carbonifere, v. 2, p. 90-102.

Patterson, S.H., and Hosterman, J.W., 1962, Geology and refractory clay deposits of the Haldeman and Wrigley quadrangles, Kentucky: U.S. Geological Survey Bulletin 1122-F, 113 p.

Peppers, R.A., 1984, Comparison of miospore assemblages in the Pennsylvanian System of the Illinois Basin with those in the Upper Carboniferous of western Europe: in Sutherland, P.K., and Manger, W.L., eds., Compte Rendu Neuvieme Congres International de Stratigraphie et de Geologie du Carbonifere, v. 2, p. 483-502.

Pfefferkorn, H.W., 1972, Distribution of Stigmaria wedingtonensis (Lycopsida) in the Chesterian (Upper Mississippian) of North America: American Midland Naturalists, v. 88, no. 1, p. 225-231.

Pffefferkorn, H.W., and Gillespie, W.H., 1979, Plant megafossils in the proposed Pennsylvanian System stratotype: Ninth International Congress of Carboniferous Stratigraphy and Geology Abstracts of Papers, University of Illinois at Urbana-Champaign, Urbana, Illinois, p. 162.

1980 , Biostratigraphy and biogeography of plant compression fossils in the Pennsylvanian of North America in Biostratigraphy of fossils plants, successional and paleocological analyses: Dowden, Hutchinson and Ross Inc., ch. 3, p. 93-118.

1981a, Plant megafossils at Carboniferous-Permian boundary [abs.]:

American Association of Petroleum Geologists Bulletin, v. 65, no. 5, p. 970 .

$1981 \mathrm{~b}$, Biostratigraphic significance of plant megafossils near the Mississippian - Pennsylvanian boundary in southern West Virginia and southwestern Virginia, in, Roberts, T.G., ed., (Geological Society of America Annual Meeting Guidebook, v. 1, fieldtrip 4, Stratigraphy and Sedimentology): Washington, D.C., American Geological Institute, p. 159-164.

1982, Plant megafossils near the Mississippian - Pennsylvanian boundary in the Pennsylvanian system Stratotype, West Virginia/virginia, in Ramsbottom, W.H.C., Saunders, W.B., and Owens, Bernard, eds., Biostratigraphic data for a mid-Carboniferous boundary: Subcommission on Carboniferous Stratigraphy, Leeds, England, p. 128-133.

Phillips, T.L., and Peppers, R.A., 1984, Changing patterns of Pennsylvanian coal-swamp vegetation and implications of climatic control on coal occurrence: International Journal of Coal Geology, v. 3, no. 3, p. 205-255.

Potter, P.E., BeMent, W.0., Elias, R.J., Goodman, W.R., Bacon, Randy, and Ho-sh in Yu, 1981, Mississippian and Pennsylvanian section on Interstate 75 south of Jellico, Campbell County, Tennessee, Tennessee Division of Geology, Report of Investigations $38,42 \mathrm{p}$. 
Read, C.B., and Mamay, S.H., 1964, Upper Paleozoic floral zones and floral provinces of the United States: U.S. Geological Survey Professional Paper 454-K, p. K1-K35.

Reger, D.B., 1926, Mercer, Monroe, and Summers Counties: West Virginia Geological Survey [County Report], 963 p.

Rice, C.L., 1984, Sandstone units of the Lee Formation and related strata in eastern Kentucky: U.S. Geological Survey Professional Paper 1151G, 53 p.

Rice, C.L., and Maughan, E.K., 1978, Geologic map of the Kayjay quadrangle and part of the Fork Ridge quadrangle, Bell and Knox Counties, Kentucky: U.S. Geological Survey Geologic Quadrangle Map GQ-1505, scale, 1:24,000.

Rodgers, John, 1953, Geologic map of east Tennessee with explanatory text: Tennessee Division of Geology Bulletin 58, $168 \mathrm{p}$.

Schweinfurth, S.P., Trent, V.A., and Helton, E.D., 1981, Geologic map of the Sipsey Wilderness and additions, Lawrence and Winston Counties, Alabama: U.S. Geological Survey Miscellaneous Field Studies Map MF-1288-B, scale $1: 50,000$.

Simon, F.0., and Englund, K.J., 1983, Test drilling for coal in 1982-83 in the Jefferson National Forest, Virginia: Part 2: Analyses of coal cores from the southwestern Virginia coal field: U.S. Geological Survey Open-File Report OF-83-620, 23 p.

Smith, E.W., 1979, The Mississippian and Pennsylvanian (Carboniferous) Systems in the United States - Alabama and Mississippi. Pennsylvanian Stratigraphy of Alabama: U.S. Geological Survey Professional Paper 1110-A-L, P. I23-I36.

Smith, A.H.V., and Butterworth, M.A., 1967, Miospores in the coal seams of the Carboniferous of Great Britain: Special papers in Paleontology No. 1, Paleontological Association, London, England, 324 p.

Thiessen, Reinhart and Staud, H.N., 1923, Correlation of coal beds in the Monongahelia Formation of ohio, West Virginia and Pennsylvania: Coal-Mining Investigations, v. 9, 64 p.

Thiessen, Reinhart and Wilson, F.E., 1924, Correlation of coal beds of the Allegheny Formation of western Pennsylvania and eastern Ohio: Coal-Mining Investigations, $\mathrm{v} .10,56 \mathrm{p}$.

Thomas, W.A., 1979, The Mississippian and Pennsylvanian (Carboniferous) Systems in the United States - Alabama and Mississippi. Mississippian stratigraphy of Alabama: U.S. Geological Survey Professional Paper 1110-A-L, P. I1-I22.

Thomas, W.A., and Cramer, H.R., 1979, The Mississippian and Pennsylvanian (Carboniferous) Systems in the United States - Georgia: U.S. Geological Survey Professional Paper 1110-A-L, P. Hl-H37.

Upshaw, C.F., 1967, Pennsylvanian palynology and age relationships: in Ferm, J.C., Erlich, Robert, and Neatherly, T.L., A field guide to Carboniferous detrital rocks in northern Alabama: Alabama Geological Society, University of Alabama, Tuscaloosa, AL., p. 16-20. 
Wagner, R.H., 1982a, Floral changes near the Mississippian - Pennsylvanian boundary: an appraisal in Ramsbottom, W.H.C., Saunders, W.B., and Owens, Bernard, eds., Biostratigraphic data for a mid-Carboniferous boundary: Subcommission on Carboniferous Stratigraphy, Leeds, England, p. 120-127.

1982b, Megafloral zones of the Carboniferous in Sutherland, P.K., and Manger, W.L., eds., Compte Rendu Proceedings Neuvieme Congres International de Stratigraphie et Geologie du Carbonifere, v. 2, p. 109-134.

Wanless, H.R., 1946, Pennsylvanian geology of a part of the southern Appalachian-coal field: Geological Society of America Memoir 13, 162 p.

Wanless, H.R., and Weller, J.M., 1932, Correlation and extent of Pennsylvanian cyclothems: Geological Society of America Bulletin v. 38, p. 97-135.

Weems, R.E., and Windolph, J.F., Jr., in preparation, A new Actinopterygian fish (Uropterygida, Uropterygidae) from the Upper Mississippian Bluestone Formation of West Virginia.

Weller, J.M., 1930, Cyclical sedimentation of the Pennsylvanian Period and its significance: Journal of Geology, v. 38, no. 2, p. 97-135.

White, David, 1900, The stratigraphic succession of the fossil floras of the Pottsville Formation in the southern Anthracite coal field, Pennsylvania, U.S. Geological Survey Annual Report, v. 20, pt. 2, p. 749-930.

1913, Climates of coal forming periods in White, David and Theissen, Reinhart, eds., The origin of coal: U.S. Bureau of Mines Bulletin 38, p. 68-79.

1925, Enviromental conditions of deposition of coal: American Institute of Mining and Metallurgical Engineers Transactions, v. 71, p. 3-34.

1926, General features of the Mississippian floras of the Appalachian trough in Reger, D.B., Mercer, Monroe, and Summers Counties: West Virginia Geological Survey [County Report], p. 837-843.

1936, Fossil flora of the Wedingt on Sandstone Member of the Fayetteville Shale: U.S. Geological Survey Professional Paper 186-B, 28 p.

1937, Fossil plants from the Stanley Shale and Jackfork Sandstone in southeastern 0klahoma and western Arkansas: U.S. Geological Survey Professional Paper 186-C, 24 p.

1943, Lower Pennsylvanian species of Mariopteris, Eremopteris, Diplothema, and Aneimites from the Appalachian region: U.S. Geological Survey Professional Paper 197-C, 56 p.

Wilson, R.L., 1975, Lower Pennsylvanian strata of the northern part of Sand Mountain, Alabama, Georgia and Tenessee: Tennessee Academy of Science Journal v. 50, no. 1, p. 20-24. 


\section{$85^{\circ}-577$}

84

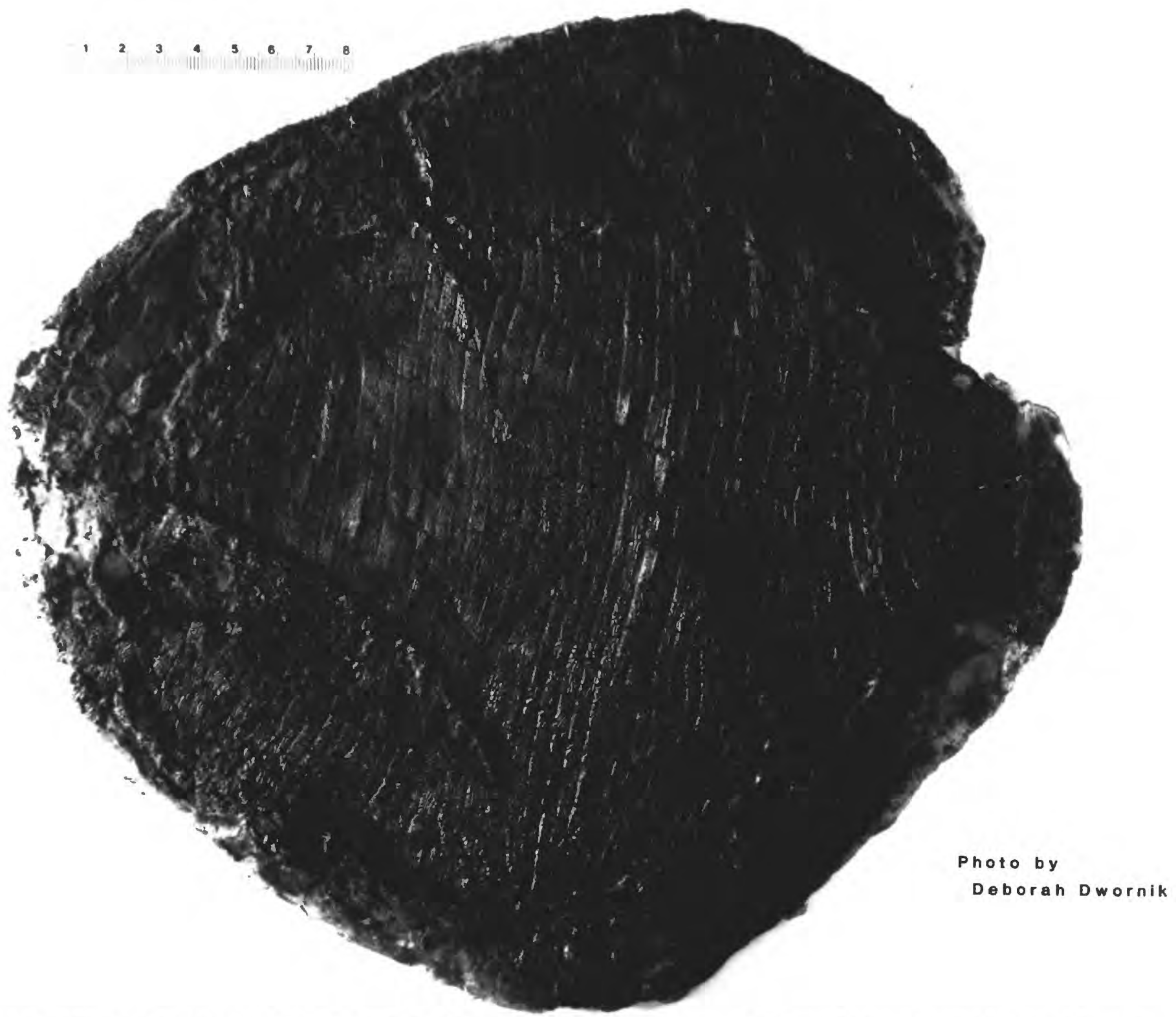

Tanypteryx pridensis from the Pride Shale Member of Bluestone Formation, Stop 2. 